

\section{BIRMINGHAM STUDIES}

IN

\section{SOCIAL ECONOMICS}

\section{AND ADJACENT FIELDS}

Edited by Professor W. J. ASHLEY

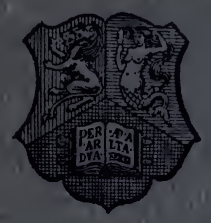

I

\section{Environment and Efficiency}

A Study in the Records of Industrial Schools and Orphanages

BY

MARY HORNER THOMSON

WOODBROOKE SETTLEMENT

WITH A PREFACE BY

J. RENDEL HARRIS, LL.D.

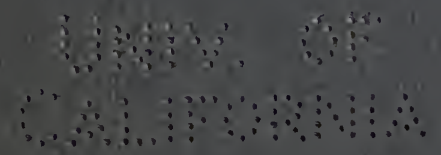

LONGMA NS, GREEN A N C O. 39 PATERNOSTER ROW, LONDON NEW YORK, BOMBAY, AND CALCUTTA 
Diglized by the Interne: Archive in 2007 with funding trom Microsoft Corporation

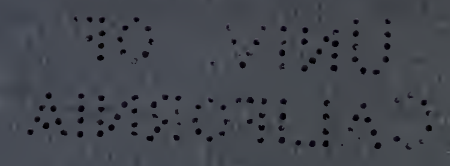


ver

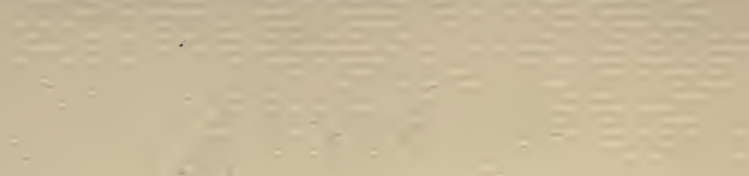

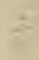

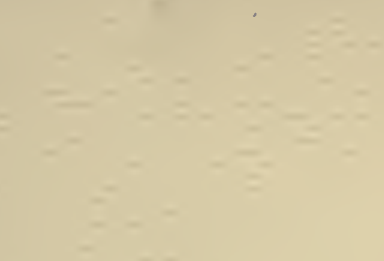



I

ENVIRONMENT AND EFFICIENCY 


\section{NOTE}

The Studies in this Series are the outcome of the inquiries of students working for the Social Study Higher Diploma or for the Higher Degrees of the University of Birmingham.

The Social Study Committee-consisting of teachers in the University, and of representatives of various institutions in the City of Birmingham-directs a course of preparation for Public and Social Service which combines systematic instruction at the University with practical training in the city under due supervision.

Those who have completed this course, or have been adequately prepared by similar or cognate studies elsewhere, may proceed to a Higher Diploma ; submitting a Thesis embodying the results of an original investigation conducted under the supervision of the Chairman of the Committee.

Copies of the Social Study Syllabus may be obtained on application to The Secretary, The University, Birmingham. 


\section{BIRMINGHAM STUDIES}

IN

\section{SOCI A L E C ONOM I C S}

AND ADJACENT FIELDS

EDITED BY

Professor W. J. ASHLEY, Ph.D.

DEAN OF THE FACULTY OF COMMERCE AND CHAIRMAN OF THE SOCIAL STUDY COMMITTEE IN THE UNIVERSITY OF BIRMINGHAM

I

\section{Environment and Efficiency}

A Study in the Records of Industrial Schools and Orphanages

BY

MARY HORNER THOMSON WOODBROOKE SETTLEMENT

WITH A PREFACE BY

J. RENDEL HARRIS, LL.D.

DIRECTOR OF STUDIES AT THE WOODBROOKE SETTLEMENT

LONGMANS, GREEN AND CO. 39 PATERNOSTER ROW, LONDON NEW YORK, BOMBAY, AND CALCUTTA 1912 


$$
\text { HM } 1150
$$




\section{PREFACE}

THE essay which occupies the following pages is something more than an academic dissertation; it is, within its elected narrow limits, a real contribution to a very pressing problem. We are all of us anxious to solve, both theoretically and practically, the problem of the man that fell among thieves and was left, only half alive, i.e. only half a man, by the roadside; but while the spirit of the Good Samaritan is increasingly with us, and to that extent benedictions multiply on those who help and, to some extent, upon those who receive help, we are all of us also increasingly aware that it is not enough to take a stricken man to a shelter, nor even to produce the financial equivalents for his restoration. We want to be assured that he will not fall among thieves a second time, in view of the fact that his journey must be continued on the same road; and in order to satisfy ourselves on that point, we have to identify and, if possible, to catch the thieves. Thus the problem of life is expanded; it began with Man, know thyself; it was re-stated as Man, know thy neighbour: and it is now becoming a question 'of the neighbour's ancestry and the neighbour's environment. More than this, the problem has an added pathos for those who love their kind, in that the man by the wayside turns out to be a child, or, at all events, as in the present investigation, an intermediary between child and man. It might have been imagined that in a properly ordered world children would at least have been secure; on the contrary, they appear to be least secure; and it is darkly hinted by the Eugenists that the child's own parents are the robbers, and that they have pauperised the

\section{1}


child in mind and body; that no good Samaritan, however many may pass along the road, will ever prevail to find real shelter, or restoration, or healing for the wounded and the hurt and the incapacitated. It is even maintained that two robbers can be identified, chief outlaws on the high-road of human life, and that of these two, Heredity and Environment, the second is powerless against the first: if he should turn pitiful, as in the case of the man that was mildest of mood in the story of the Babes in the Wood, he will not be strong enough to stay his mate; we are dealing with factors, of which the first is irremediable, even if the second should be removable or capable of melioration. At least this appears to be the judgment of a certain very logical school of Eugenists. Miss Thomson, in the pages that follow, attempts to apply the test of statistical experiment to the problem, and to find out for us whether Environment is adequate to unsay what Heredity has been proclaiming ore rotundo; her close and careful investigations, not disfigured by undue optimism, will be encouraging to those who believe that both man and his world can be made demonstrably better, and do not insist that it shall be done all at once (in which plea for the help of adequate Time they appear to have the backing of the Intelligent part of the Universe itself).

The problem is not a new one, in any sense except that the study is closer, and the statistics more extended: all philosophers are at work upon it, and all saints. Here is a suggestive extract from the writings of Jacob Boehme, who qualifies both as philosopher and as saint. According to Jacob, what we have to know is the Signatura Rerum, the hidden quality which is expressing itself in Nature and especially in Organic Nature and Life; for, says he:-

"If an herb be transplanted out of a bad soil into a good, then it soon gets a stronger body, and a more pleasant smell and power, and shows the inward essence externally; and there is nothing created or born in nature, but it also manifests 
its internal form externally, for the internal continually labours or works itself forth to manifestation; ... therefore the greatest understanding lies in the signature wherein man (viz. the image of the greatest virtue) may not only learn to know himself, but therein he may learn to know the essence of all essences ; . . . the fiat of that essence forms the quality of the essence in the voice or virtue which it sends forth."

It will be at once pointed out that Jacob Boehme's words may be taken in two opposite senses; for the Essence of which he speaks is elusive, and the Signatura Rerum may be our old enemy (or disguised friend), Heredity. Who shall decide? Who will tell us whether there is any certain road from the manifestation of the children of the drunkard and the dissolute to the manifestation of the sons of God? It is not for me to frame the answer: all I have to do is to ask for a proper scrutiny of the facts presented by Miss Thomson and the conclusions which she suggests.

RENDEL HARRIS. 



\section{CONTENTS}

SECTION

PAGE

I. INTRODUCTION • • . . . . . . I

II. Scope AND Methods of Investigation . $\cdot$. 9

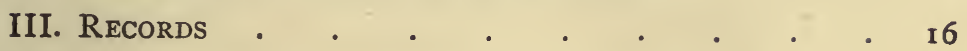

IV. Institutional Training . $. \quad . \quad . \quad . \quad 68$

V. Conclusions . $\quad . \quad$. $\quad . \quad . \quad . \quad 85$

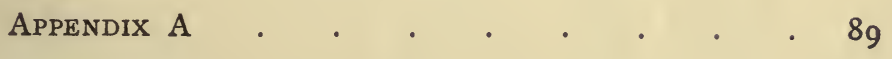

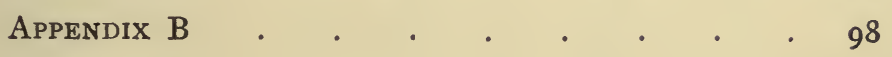

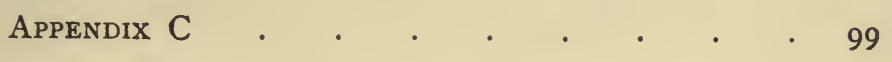





\title{
Environment and Efficiency
}

\author{
SECTION I
}

\section{INTRODUCTION}

MY chief purpose in writing this thesis has been to show by a collection of definite results the overwhelming part played by environment in the building-up of human efficiency.

Perhaps it will be well to state in the first place what I have taken as my standard of "efficiency." Mr. Charles Booth, in his Labour and Life of the People, classes the population of East London as follows :-

\begin{tabular}{|c|c|c|c|c|c|c|c|}
\hline Class A. & B. & C. & D. & E. & F. & G. & H. \\
\hline $\begin{array}{c}\text { The } \\
\text { Lowest } \\
\text { Class, } \\
\text { consisting } \\
\text { of "some } \\
\text { occasional } \\
\text { labourers, } \\
\text { street } \\
\text { sellers, } \\
\text { loafers, } \\
\text { criminals, } \\
\text { and semi- } \\
\text { criminals." }\end{array}$ & $\begin{array}{l}\text { The Very } \\
\text { Poor, who } \\
\text { exist on } \\
\text { casual } \\
\text { earnings ; } \\
\text { "many of } \\
\text { them in- } \\
\text { evitably } \\
\text { poor from } \\
\text { shiftless- } \\
\text { ness, help- } \\
\text { lessness, } \\
\text { idleness, } \\
\text { or drink." }\end{array}$ & $\begin{array}{c}\text { The Poor, } \\
\text { supported } \\
\text { by inter- } \\
\text { mittent } \\
\text { earnings, } \\
\text { engaged in } \\
\text { seasonal or } \\
\text { irregular } \\
\text { work; very } \\
\text { generally } \\
\text { "'hard- } \\
\text { working, } \\
\text { though } \\
\text { shiftless } \\
\text { and im- } \\
\text { provident." }\end{array}$ & $\begin{array}{l}\text { Those who } \\
\text { although } \\
\text { they have } \\
\text { small } \\
\text { regular } \\
\text { earnings } \\
\text { cannot be } \\
\text { said to rise } \\
\text { above } \\
\text { Poverty ; } \\
\text { " as a } \\
\text { general } \\
\text { rule have } \\
\text { a hard } \\
\text { struggle to } \\
\text { make ends } \\
\text { meet, but } \\
\text { are, as a } \\
\text { body, } \\
\text { decent, } \\
\text { steady men, } \\
\text { paying } \\
\text { their way } \\
\text { and bring- } \\
\text { ing up their } \\
\text { children re- } \\
\text { spectably." }\end{array}$ & $\begin{array}{l}\text { Those } \\
\text { above the } \\
\text { Poverty } \\
\text { Line, who } \\
\text { earn from } \\
\text { 22s. to } 30 \text {. } \\
\text { per week } \\
\text { for regular } \\
\text { work. This } \\
\text { class in- } \\
\text { cludes } \\
\text { carmen, } \\
\text { porters, } \\
\text { warehouse- } \\
\text { men, per- } \\
\text { manent } \\
\text { dock } \\
\text { labourers, } \\
\text { \&c. }\end{array}$ & $\begin{array}{l}\text { Higher } \\
\text { Class } \\
\text { Labour } \\
\text { and the } \\
\text { best paid } \\
\text { artisans } \\
\text { and } \\
\text { foremen. }\end{array}$ & $\begin{array}{c}\text { Lower } \\
\text { Middle } \\
\text { Class; } \\
\text { shop- } \\
\text { keepers, } \\
\text { small } \\
\text { employers, } \\
\text { clerks, \&c. }\end{array}$ & $\begin{array}{l}\text { Upper } \\
\text { Middle } \\
\text { Class; con- } \\
\text { sisting of } \\
\text { all those } \\
\text { above G- } \\
\text { may be } \\
\text { shortly } \\
\text { defined as } \\
\text { "the } \\
\text { servant- } \\
\text { keeping } \\
\text { class." }\end{array}$ \\
\hline
\end{tabular}


Suppose we can take a member of the loafing, criminal, or semi-criminal Class $\mathrm{A}$, and transplant him into Class $\mathrm{D}$, thus transforming him into a "regular wage earner, a decent, steady man who will pay his way and bring up his children respectably" ; then, in spite of the fact that he still dwells on the wrong side of the "poverty line," I venture to think that, in consideration of the class from which he has sprung, and more especially in consideration of the decent home which he is able to provide for his children, we may characterise him as efficient.

The majority if not all the children with whom these records deal are children born into Class $A$; that is to say, they are the children of criminals, of drunkards, of prostitutes, and of vagrants; in some cases they have been "found wandering " or "deserted," or " under improper guardianship "; in others they have been themselves convicted of petty theft, and are therefore fast qualifying for a criminal career.

It does not seem necessary to collect statistics, to prove that, left to themselves, these children would inevitably form the Class A of a future generation. Under such circumstances there could be no pitched battle between Heredity and Environment; and the results which each unaided might fail to bring about, their combination would surely achieve.

The term "efficiency" is necessarily a relative one; and in dealing with the evidence I have collected, I have considered in every instance not only the record of the child as it grew to manhood or womanhood, but also the record of the parents.

"Inefficiency" is also a relative term; but, looked at in the light of these parental records, it is in almost every case synonymous with vagrancy, with dissolute living, with drunkenness, and with crime. There are, of course, isolated instances where the record has been one of accumulated misfortune, rather than of inefficiency; but these are so rare as to be swamped in the general whole.

Before proceeding further it may be as well to refer to the extreme position adopted by some members of the Eugenic 
Society. Mr. C. P. Mudge, in the Mendel Journal for $\mathbf{1 9 0 9 ,}$ says :- "It is tacitly assumed by the exponents of this sentiment (the sentiment of the modern social reformer), that the qualities of the individual depend upon his environment, that he is vicious because of the viciousness of his surroundings, and good because his environment is made up of good influences.

"It is entirely wrong-there is no justification for it in all the realms of fact. The very converse is true, for in social life the environment is the product of the individual, and not vice versa.

"The stunted individuals are not the product of a oneroomed tenement, but the one-roomed tenement is the expression of the inherent incapacity of this race to be able to do anything better for itself; it is the natural outcome of their already existing physical, moral, or intellectual degeneration. These degenerates are 'mutations,' and breed true to their degeneracy."

Again, referring to the Tasmanians, Mr. Mudge says :"The life they lived was the product of their desires. They were not the product of their mode of life; they made their life, not their life made them. It is the same with our own social classes. The mode of life of the higher strata is the outcome of their inherent qualities, in just the same way that the mode of life in the lower is the outcome of their inborn desires and capacities. The higher classes are the outcome of their evolution, the lower of theirs. The social conditions are the products of the social classes, not the social classes the products of social conditions."

Extravagant statements of this kind are obviously open to criticism. In the first place, few people who have seriously studied this subject are prepared to maintain that environment is the only factor in determining character. They admit that within certain limits we are hereditarily determined; that, as Professor Thomson says, "Heredity, function and en- 
vironment;-what the living creature is, or has to start with, in virtue of its hereditary relation, what it does in the course of its activity, what surrounding influences play upon it,these are the three determining factors of life." 1 What they hesitate to accept are such sweeping statements as those just quoted, which entirely eliminate Function and Environment as determining factors of character.

Again, Mr. Mudge asserts that "vice" or "degeneracy" occurs originally as a "mutation" (i.e. a spontaneous variation), and is thus handed down in the germ-plasm from one generation to the next. But if we admit that our Class $\mathrm{A}$ is largely made up of "degenerates," how can we prove that what may have arisen as a "variation" is necessarily handed down?

To quote Professor Thomson again, "Variations are more or less transmissible, but they are not always transmitted. ... Even where there is reason to believe that an offspring has inherited a predisposition to a particular disease, it does not necessarily follow that this item in the inheritance must be expressed in development. ${ }^{2}$... If it does not find appropriate nurture it will not express itself; it may simply lie latent and be expressed in the next generation. Eventually, whether it find expression or not, it may die away altogether -just as useful variations seem sometimes to disappear." 3

The question naturally arises how are we to distinguish between what is "innate," i.e. arising as a germinal variation, and what has been "acquired"-as the result of nurture or function. For instance, a disease which persists in a family for several generations may have originated, in the first place, not as a "variation" but as a "modification"-the result of an unhealthy neighbourhood or trade; but if the same conditions are reimpressed on each succeeding generation, that is, if the children live in the same environment and work at the same

1 Heredity, p. 3.

2 Ibid., p. 296.

3 Ibid., p. 258 , 
trade as their fathers, the reappearance of the disease is not necessarily a case of heredity at all. It is the external conditions which are hereditary rather than the disease.

But even if we allow that a disease-whether physical or moral-is a matter of heredity, or rather the predisposition to that disease-because a disease as such is never inheritedthen what is our position?

"I. If it does not find appropriate nurture, it will not express itself.

2. Or it may lie latent and express itself in the next generation.

3. Or it may eventually disappear altogether."

In Professor James' famous chapter on "Instinct" 1 there is an illustration of the "inhibition" of certain instincts through want of appropriate "stimuli." He relates the case of a young puppy removed from a stable, where he had been wont to burrow in the earth for a hidden bone, to a lady's drawingroom. For a day or two the puppy amuses himself at the same game, but the appropriate stimuli are all missing. A glove is a poor substitute for a bone; the carpet is not the stable floor, and, as the puppy has been regularly fed, the chief incentive of hunger is also missing. Eventually he loses interest in his purposeless game, and the instinct is inhibited; so that when similar stimuli reappear in later life he will not respond. The analogy is obvious.

Let us suppose the child of a thief inherits his father's criminal instincts-which is doubtful-or suppose that he has himself been convicted of petty theft. If removed from his unsatisfactory surroundings to a decent home, given a different standard of behaviour, and trained in habits of obedience and self-control, when the temptation comes to him in later life the instinct will probably be inhibited. It will be inhibited because the appropriate "stimuli" supplied by his early environment, which, put briefly, were the forces of

1 Principles of Psychology, vol. ii. p. 339. 
suggestion, of imitation, of hunger and want, have so long been missing that when they again make their appearance the instinct is either dead or controlled by habit.

To refer again to the extreme importance of the child's external inheritance. One hears so often the expression that "so and so has inherited his mother's brilliance, or his father's piety." This may be the case, but it is equally true that the mother's mode of thought, the father's attitude towards life, in fact the whole personality of that mother and father, are commonly part of the child's external inheritance.

Let us contrast this fair inheritance with that of the slum child, who is said to inherit his mother's viciousness, his father's criminal tendencies. Upon whose horizon does the personality of the parents loom largest? Upon that of a child growing up in the atmosphere which all good and cultivated persons so insensibly create around them; or upon that of our little "hereditary criminal" who, during all the early and most impressionable years of his life, lives, eats, and sleeps in one poor room, which he shares with his drunken and dissolute parents, and which is pervaded by that atmosphere which they also so insensibly create around them?

There comes also the question whether the environment, with its ensuing modifications, may not in course of time, in a sense, induce innate variations.

"Modifications that are effectively advantageous-adaptive responses in fact-may have an indirect evolutionary importance; for they may serve as sheltering, life-preserving, or welfare-furthering screens, until coincident variations in the same direction have time and opportunity to establish themselves. Thus a modificational change may be gradually replaced by a strictly variational and by hypothesis heritable one." 1

Let us suppose a member of the Class $H$ group to be ${ }^{1}$ J. A. Thomson, Heredity, p. 516. 
unfortunate in business. In the majority of cases his relatives come to his assistance, and he is helped on to his feet again ; he does not descend into the class below, but remains in his own, though possibly as an inefficient member, and his children do not necessarily suffer. But suppose a member of Class E, who is above the poverty line and in regular work, loses his situation through illness or no fault of his own. His relations-who, if they are in the same class as himself, are earning from twenty-two, to thirty shillings a week-are not in a position to help him, and he may slip gradually down through the intervening classes into Class B. For this man's children the whole aspect of life is changed. In place of the respectable neighbourhood where they formerly dwelt is substituted a mean street with all its sordid associations and undesirable acquaintances. Food is no longer so plentiful nor probably in course of time so daintily prepared, for the mother of the family in many cases is by now its main support. The boys as they leave school are hustled into the first "blind alley" occupation which presents itself, instead of being apprenticed to their father's trade as would formerly have been the case. For now the family circumstances are such that forethought in matters of this kind has become impossible; the claims of the present are too insistent. Then the youth, as he becomes too old for his first job, has a long period of looking for work; and experts in "boy labour" are continually telling us what will be the probable result of such a course.

Does it not seem likely that the children of the third generation will have sunk into Class A; and that in course of time, if "degeneracy" and "vice" do indeed arise as spontaneous "variations," such an environment as Class B represents, with its ensuing modifications, may have "acted as a screen until variations in the same direction (i.e. in the direction of degeneracy and crime) have had time and opportunity to establish themselves." 
Nowadays there are statisticians who prove to us that the "correlation" between the mental capacity of the elementary school child and that of its parent is infinitely greater than the correlation between the mental capacity of that child and its environment; and in the same way that the mental ability of the Oxford undergraduate has a much greater correlation with the mental ability of his father and brothers than with his and their environment. But each of these calculations is based solely upon the child in relation to its usual environment. Has anyone worked out the correlation between the efficiency of the young person trained in an institution or cottage home and his efficiency if left in his previous environment, or between the efficiency of the young person so trained and that of the parent in the Class A from which he has sprung? Have they taken a child of the upper or middle-classes and submitted it to a Class A environment, and then, as they watched its subsequent development, found the correlation between this result and what he would have been if left in his earlier environment? And if this has not been done, are we in a position to regard environment as a negligible quantity in the formation of character.

It seems to me that, until it can be proved to us that the transformation we see effected in these children is but a superficial growth doomed to be uprooted by the strong arm of Heredity, for every drunkard we pass in the street, for every criminal who is driven past us in a prison van, we are bound to say-to paraphrase the words of John Bradford"There, but for the force of circumstances, go I!" 


\section{SECTION II}

\section{SCOPE AND METHODS OF INVESTIGATION}

WHEN I first started upon this inquiry, I intended to confine my investigations principally to the records of Poor Law children; that is to say, children brought up in Poor Law institutions, or those boarded out by the same authority. But the importance of keeping such records, dealing with the subsequent careers of children trained in institutions, whether Poor Law or otherwise, appears, until quite recently, to have been underestimated by the majority of institution authorities. Again, I naturally tried to restrict my investigation as far as possible to institutions in my immediate neighbourhood, and this necessarily limited the number of Poor Law Homes at my disposal.

At the Homes to which I first went no written records were kept.

At the Cottage Homes I next visited the superintendent had been there too short a period for the records to be of any value, and the previous superintendent had not kept any. At first I thought I could make use of the Admission and Disposal Books. But I soon found that the children were so usually taken out by their parents within a year or two that records of adequate length were extremely difficult to find. Of the first thirty cases looked through, not one stayed long enough to be significant for my purpose. Taking a page elsewhere at random, I found that, of the thirty names it contained, nineteen had been taken out by parents within a year or two, six had been transferred to the local Union, one to the Infirmary, and four were unaccounted for. Under these circumstances I came to the conclusion that the 
time at my disposal would be better employed in seeking material elsewhere.

Before leaving the subject of local Poor Law Institutions, I might mention that with regard to "Children Boarded Out" by a certain Union, I received the following information from the secretary:-

"The Guardians of this Union intend to keep records of the after-careers of the children boarded out by them.

"No child has yet been placed out, who has been boarded out by the Guardians, either within or beyond the Union. The eldest child at present boarded-out is just I4 years old."

Of the fifteen "Homes, Schools, Orphanages, \&c. for Children," whose names are supplied in the "List of Charities and Charitable Institutions and Societies" compiled by the local Charity Organisation Society, I wrote to eight. Of the remaining seven, two stipulate that the children shall be of "good character or respectable parentage," and are therefore of no use for the purpose of this inquiry; two prefer them to be over fifteen years of age; one keeps whatever records it may have at headquarters; and the other two did not appear to be specially suitable for my purpose.

Of those eight to which I wrote, I visited and obtained records from three. Of the remainder, one Catholic association forwarded me a copy of its Annual Report. This contained a number of short records and a list of skilled trades to which boys had been apprenticed. I have placed this list in Appendix A. The others, although they appeared to keep in touch with their children as far as possible, had not the time to keep written records, with the exception of one institution where the superintendent kept them in shorthand.

The three whose records I investigated were:-

I. The Y. Children's Emigration Homes, supported by private charity.

II. The X. Home for Boys, also a private charity.

III. A Certified Industrial School. 
These were all the local records I was able to obtain.

In the case of II., which is a small home, the records were given me from memory by the lady superintendent, and I took them down at her dictation.

Besides these local records I obtained others from the following sources :-

IV. A Girls' Industrial School in the South of England, from a case-book lent to me by the lady superintendent.

V. A Boys' Industrial School in the North.

VI. Records of twenty children boarded-out by the Glasgow Parish Council; for which I am indebted to the kindness of Dr. Leslie Mackenzie.

Besides these records, 295 in all-which, with the exception of the 20 procured for me by Dr. Mackenzie, were the result of my own personal investigation-I received a certain amount of information, more or less relevant to my subject, from the secretaries of 20 Poor Law Schools, Voluntary Homes, and Certified Industrial Schools, in different parts of the country, of whom I made inquiries. I quote from the information sent me by nine of these in Appendix A.

My method of collecting the records was as follows: When the books had been placed at my disposal, I opened the Admission Book (in which each child's history is entered) at a date sufficiently remote to allow of a record of available length. I did not, for instance, start from the year 1907, because I knew that by 1912 the child would barely have left the institution, and could not possibly possess any record worthy of the name. An exception to this rule was necessarily made in the case of the Emigration Homes, where the child is sent out either in the same year or the year following its admission; and I have therefore taken the record from that time onwards.

Having found a suitable starting-place, I proceeded to take the names in consecutive order. I mention this to show that 
my records are not in any sense "picked ones," but are taken in the order in which they came, starting from a given date.

To this rule there had also to be exceptions.

(a) Where, as in dozens of cases, the records had been kept an insufficient time, I passed on. My minimum period was four years.

To this again I made exceptions in the case of (I) The North of England Industrial School, from which I got, in all, eighty records. These were so particularly well kept that I was anxious to collect as many as possible, and the last ten or so have only a three years' record up to the end of I9II. Most of these were from boys settled in Canada, and the letter or report for 1912 had not yet arrived at the time of my inquiry. As in the seventy other records which I had collected there was not one really unsatisfactory case, it seemed fair to conclude that when the fresh report arrived it would be found as satisfactory as in previous years.

(2) The X. Home for Boys.--Several of these boys, though starting work at fourteen or fifteen, continued to live in the Home until eighteen years of age. One or two of the records, I believe, are under the four years' minimum; but I particularly wished to include the information from this Home, as I consider it valuable as illustrating the sort of work for which boys of this class may be prepared.

(b) Where, as in two of the Industrial Schools, some children came from "respectable" homes, I omitted these wherever known, and passed on to those whose previous environment had been evidently unsatisfactory.

I mentioned that I took four years for my minimum record. The average record of the 200 cases of which I have the exact dates extends over 8 .I years.

Of the remaining ninety-five, I find I have not entered the length of record-most, if not all, of these being doubtful cases.

Ten of the 200 records have been kept for a period of 
twenty years and upwards, 36 for ten years and upwards, and only 32 for four years or less.

And if there are some who argue that it is impossible to draw any satisfactory conclusions from a four years' record, I would draw their attention to such statements as the following :-

"Under existing conditions those members of the workshy class who have never done any regular work, have spent the five precious formative years between I4 and I9, when they were not engaged on casual jobs of no educational value whatever, in hanging about the streets. Scarcely any better system for producing a class of loafers could be devised, and there is little hope of effecting any satisfactory reduction in the number of the work-shy unless strong influences are brought to bear upon them in the critical years after they leave school." 1

"In the return of 1899 it appears that 40 per cent. of boys leaving London schools became errand boys, van-boys, \&c. . . . The industrial biographies received show clearly that there is generally a time of transition when boys have to seek new occupations for which they have little or no aptitude. They begin all over again, and may or may not be able to fit themselves for their new position. The main question is whether their previous years have benefited or deteriorated them; whether, in fact, they have been improved or worn out and wasted from the standpoint of their own industrial fitness as producers and wage-earners." 2

Again: "The boys who fail, or partially fail in life, drift almost from the moment they leave school. Perhaps they leave their first place within a few days, should the work be at all difficult or the hours long. Within six months the permanent out-of-works of the future are hanging about the playground gates, whence they soon remove to the street corners." 3

1 Rowntree and Lasker, Unemployment (rgri), p. 195.

2 Cyril Jackson, Report on Boy Labour (Report of Commission on the Poor Laws, Appendix, vol, xx., rgog), pp. 4,7 .

s loid., p. rr. 
The extreme economic importance of regular and suitable employment during the first critical years after leaving school is the point insisted upon by the authors of these and dozens of similar statements. But if it is correct to infer that the outof-work and unemployable of forty is the outcome of the youth who enters a blind ally occupation or hangs about street corners at eighteen, nineteen, and twenty, it is surely equally fair to infer that the youth satisfactorily employed until twenty will probably be the man satisfactorily employed at forty.

I have classified my records as follows :-

(a) Satisfactory.

(b) Fairly satisfactory, or doubtful.

(c) Unsatisfactory.

From many of the outside institutions to which I wrote, I received their annual estimate of satisfactory or unsatisfactory children turned out by them. But, in cases like these, the difficulty arises of the need of a common standard.

As the lady superintendent of the $X$. Homes said to me, referring to a Home for Boys in the same neighbourhood, "What they would count satisfactory would not satisfy us at all. Our standard is so much higher." Or, again, another superintendent: "My own opinion is, you must not take the various classifications too literally; they are broad and general ; the opinions (perhaps loosely formed sometimes) of district visitors, some keen and interested, some only casual."

And because of this unavoidable looseness of definition, I felt with regard to the institutions whose records I investigated, that it was infinitely more conclusive to personally go through a limited number of cases from each Home and submit them all to one standard than to accept unquestionably the annual statistics upon the subject, and then proceed to search for supposedly representative cases.

With regard to the small number of records I have taken from some of the Homes, my apology must be the length of time involved in collecting even a little satisfactory evidence. 
This was due (I) to the numerous exceptions to the rule of a consecutive order, to which I have already referred; and (2) in the case of the Emigration Homes, where the cases are kept on the Shannon File system, to the time required to hunt through the records. They here included reports from employers, reports from the appointed visitor, letters from employers, and letters from the children themselves. But this completer information was often more satisfactory than that given by the Industrial Schools, where simply the gist of reports, letters, \&c., was entered in the Disposal Book. In the last Industrial Home investigated, however, I was myself able to read through a pile of letters from old boys.

In concluding this section I should mention that my investigations have dealt solely with the normal child, using the word "normal" as opposed to the "mentally or physically defective," classified as such. Both in the Emigration Homes and in the Industrial Schools, the rule is to exclude the mentally defective; and, where such cases crop up, the defect has probably not been sufficiently advanced at the time of admission to be notifiable. 


\section{SECTION III}

\section{RECORDS}

IN this section I give records obtained from the six different sources already referred to in Section II., namely :-

The Y Emigration Homes.

The Industrial School for Girls.

Boys' Industrial School (No. I).

Boys' Industrial School (No. 2).

The $\mathrm{X}$ Home for Boys.

Children boarded out by the Glasgow Parish Council.

Before tabulating the records, I have given some account of the nature and scope of each institution, either by quotations from its annual report, by quotations from the report of the Government Inspector of Industrial Schools, I910, or from my own personal observation.

With regard to these institutions I do not, however, attempt to give any detailed account of their organisation, nor to compare the relative advantages or disadvantages of different methods of administration. There could be no point in recapitulating the exhaustive information on this subject to be found both in the Majority and Minority Reports of the Poor Law Commission, 1909. Besides, it seems to me that in the past too much attention has been devoted to statistics having regard to the administration and financial returns of these institutions, and far too little to those human results by which alone, from a practical point of view, their existence can be justified. Therefore, the object of this thesis is to deal entirely with results.

In reference to my records I wish also to suggest that there are certain conditions or influences which one would 
expect in the majority of cases to produce unsatisfactory or doubtful results. These are :-

(a) Mental defect.

(b) Admission at an age when it is too late to counteract the effect of previous environment.

(c) In cases of "boarding out," or apprenticeship in Canada :-

I. An unsatisfactory new home.

2. A possible bias on the part of the employer who makes the report.

3. The fact that the case is reported on by more than one visitor.

4. A constant change of homes.

(d) A return to the original environment.

\section{The Y. EMigration Homes.}

"These homes were established in 1872 to save boys and girls from vicious, pauperising, and criminal surroundings.... . The method adopted is that of permanently removing them from the environment amid which they were born and bred, and transferring them by means of emigration to entirely different and hopeful associations. In a word, they emigrate children from a slum to a Canadian farm.

"The emigration system fights heredity by new environment. The children are led out of temptation and delivered from the evil of their associations. They lived in what are well called 'black areas,' in an atmosphere of filth and drink, of starvation, overcrowding, and open immorality. They knew evil without a chance of knowing good, and would join naturally in drunkenness and vice without dreaming of a possible alternative.

"Each year 130 children or more are taken from slum life to country homes in Canada. . . . Over 4200 children have been taken to Canada from our Emigration Homes, and have been placed in the main on farms where the conditions of their lives are precisely opposite to those of slums." 1 
Sources from which Children were derived during 1910.

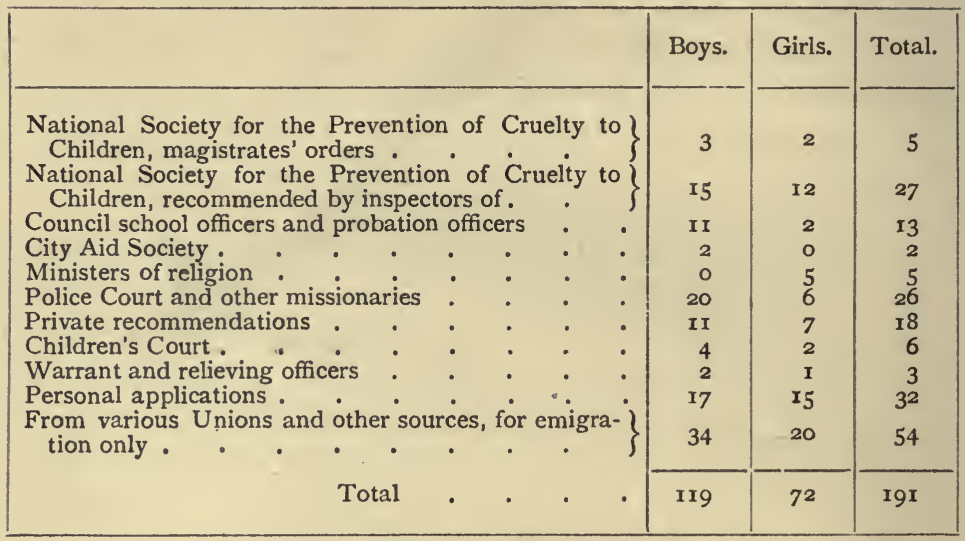

Reasons for admitting Children during $19 \mathrm{ro.}$

\begin{tabular}{|c|c|c|c|}
\hline (t) & Boys. & Girls. & Total. \\
\hline Treated with criminal cruelty by parents or guardians & 7 & 9 & 16 \\
\hline Street arabs-practically homeless . . . & 8 & 2 & Io \\
\hline Drunken and criminal parents or guardians & 34 & 22 & $5^{6}$ \\
\hline Children who have appeared before magistrates . & 3 & 0 & 3 \\
\hline Cases of pauperism and abject destitution & 22 & 17 & 39 \\
\hline Cases where children themselves are chiefly to blame & II & 2 & 13 \\
\hline $\begin{array}{l}\text { From various Unions and other sources, for emigra- } \\
\text { tion only }\end{array}$ & 34 & 20 & 54 \\
\hline Total & II9 & 72 & IgI \\
\hline
\end{tabular}

Canadian Statistics for I910.

\begin{tabular}{|c|c|c|c|c|}
\hline \multicolumn{2}{|l|}{ Visitor. } & No. Visited. & Satisfactory. & Unsatisfactory. \\
\hline $\begin{array}{l}\text { Mr. F. G. } \\
\text { Mrs. F. G. : } \\
\text { Mr. G. J. }\end{array}$ & : & $\begin{array}{r}611 \\
4 I \\
60\end{array}$ & $\begin{array}{r}5^{82} \\
39 \\
5^{8}\end{array}$ & $\begin{array}{r}29 \\
2 \\
2\end{array}$ \\
\hline Total & . $\quad$. & 712 & 679 & $33^{1}$ \\
\hline
\end{tabular}

1 These tables are all from Annual Report, 19ro, Y. Emigration Homes. 


\section{Records}

I went through 40 records, taking those of 20 boys and 20 girls. Of these $40-$

28 were entirely satisfactory.

$8\left\{\begin{array}{l}2 \text { girls } \\ 6 \text { boys }\end{array}\right\}$ were doubtful or only fairly satisfactory.

$4\left\{\begin{array}{l}2 \text { girls } \\ 2 \text { boys }\end{array}\right\}$ were unsatisfactory.

Comparing these results with the "Canadian Statistics for I9IO," previously given, it will be seen that my proportion of unsatisfactory or doubtful cases is somewhat greater. But in the Canadian statistics there is no mention of doubtful or only fairly satisfactory cases; and as in so large a number it is practically certain that some such must have occurred, it is probable that, not being definitely unsatisfactory, they were classed with the satisfactory cases.

The average record of 37 of the 40 cases of which I have taken down the dates is 6.1 years.

These records differ considerably from the remainder of my records, being kept from the year of emigration to Canada, as compared with, in the other cases, the year when institutional training ceases, or the year when children cease to be "boarded out."

It will be seen that many of these children are sent out when quite young, so that during the earlier years the record compares rather with that of the child at school than with that of the boy or girl who has started out in life. The average age to which the records quoted are kept is only 17.5 years.

I am aware that on these grounds the records may not appear so satisfactory as those of other Homes, where the records are kept to a much later age. On the other hand, it is during those precious "formative years between I5 and 20," to which I have already referred, that the majority of these children give proof of being satisfactorily employed.

The records all start from 1902; and for obvious reasons 
the real names and initials have not been employed, and the last report in satisfactory cases has sometimes been omitted if it mentioned locality.

Types of Satisfactory Cases.

\begin{tabular}{|c|c|c|c|c|c|}
\hline \multirow[b]{2}{*}{ Name. } & \multicolumn{2}{|c|}{ Age. } & \multirow[b]{2}{*}{$\begin{array}{l}\text { Previous } \\
\text { History. }\end{array}$} & \multirow{2}{*}{ Record. } & \multirow{2}{*}{$\begin{array}{l}\text { Nature of } \\
\text { Home in } \\
\text { Canada. }\end{array}$} \\
\hline & $\begin{array}{l}\text { On Emi- } \\
\text { gration. }\end{array}$ & $\begin{array}{l}\text { On Ter- } \\
\text { mination } \\
\text { of } \\
\text { Record. }\end{array}$ & & & \\
\hline $\begin{array}{l}\text { r. } \\
\text { Charles } \\
\text { F. }\end{array}$ & $\begin{array}{c}\text { I9OI } \\
\text { II }\end{array}$ & 18 & $\begin{array}{l}\text { Father dead. } 7 \\
\text { children, partly } \\
\text { kept by neigh- } \\
\text { bours. Mother } \\
\text { earns } 4 \text { s. } 6 \mathrm{~d} \text {. } \\
\text { weekly charing. } \\
\text { Obliged to part } \\
\text { with children. }\end{array}$ & $\begin{array}{l}\text { 1903. Charles is } \\
\text { happy and well- } \\
\text { liked. Goes to } \\
\text { school in the } \\
\text { winter, to Sun- } \\
\text { day School and } \\
\text { meeting. } \\
\text { Igo5. Boy now } \\
\text { hires himself } \\
\text { out, was on } \\
\text { d rive th i s } \\
\text { spring. This boy } \\
\text { rog. Thise } \\
\text { is now of age, } \\
\text { and working } \\
\text { on a lu m ber } \\
\text { boom. }\end{array}$ & $\begin{array}{l}\text { Peoplein humble } \\
\text { circumstances. } \\
\text { Boy receives } \\
\text { good treatment. } \\
\text { r9o7. Home } \\
\text { fairly satisfac- } \\
\text { tory. Satisfactory } \\
\text { rgo8. Satisfough. } \\
\text { though rough }\end{array}$ \\
\hline $\begin{array}{l}2 . \\
\text { John B. }\end{array}$ & 12 & 17 & $\begin{array}{l}\text { Parents separ- } \\
\text { ated. Mother } \\
\text { living with an- } \\
\text { o ther ma n. } \\
\text { Father been a } \\
\text { great drunkard, } \\
\text { in gaol several } \\
\text { times, now in } \\
\text { consumption. } \\
\text { Boy a street } \\
\text { arab. }\end{array}$ & $\begin{array}{l}\text { I903. Boy lazy } \\
\text { and careless, } \\
\text { going to school. } \\
\text { June I9o3. } \\
\text { Grown a nice } \\
\text { boy, very happy. } \\
\text { I905. Bright and } \\
\text { intelligent, go- } \\
\text { ing to school, } \\
\text { rather free of } \\
\text { speech. } \\
\text { rgo7. This young } \\
\text { man is now } \\
\text { on his own } \\
\text { account i has } \\
\text { grown to be } \\
\text { a big, strong- } \\
\text { looking chap. }\end{array}$ & $\begin{array}{l}\text { 1903. Boy has a } \\
\text { splendid home, } \\
\text { and would have } \\
\text { a grand chance } \\
\text { if he knew how } \\
\text { to appreciate it. } \\
\text { 1905. Treated } \\
\text { as one of the } \\
\text { fanily. }\end{array}$ \\
\hline
\end{tabular}


Types of Satisfactory Cases-(Continued).

\begin{tabular}{|c|c|c|c|c|c|}
\hline \multirow[b]{2}{*}{ Name. } & \multicolumn{2}{|c|}{ Age. } & \multirow[b]{2}{*}{$\begin{array}{l}\text { Previous } \\
\text { History. }\end{array}$} & \multirow[b]{2}{*}{ Record. } & \multirow[b]{2}{*}{$\begin{array}{l}\text { Nature of } \\
\text { Home in } \\
\text { Canada. }\end{array}$} \\
\hline & $\begin{array}{l}\text { On Emi- } \\
\text { gration. }\end{array}$ & $\begin{array}{l}\text { On Ter- } \\
\text { mination } \\
\text { of } \\
\text { Record. }\end{array}$ & & & \\
\hline $\begin{array}{l}\text { 3. } \\
\text { Herbert } \\
\text { T. }\end{array}$ & $\begin{array}{c}1902 \\
10\end{array}$ & 18 & $\begin{array}{l}\text { Father dead. } \\
\text { Mother a great } \\
\text { drunkard ; sent } \\
\text { to gaol for neg- } \\
\text { lect of child; } \\
\text { now in work- } \\
\text { house infirmary } \\
\text { owing to filthy } \\
\text { condition of } \\
\text { head. No home; } \\
\text { prosecuted by } \\
\text { N.S.P.C.C. }\end{array}$ & $\begin{array}{l}\text { I907. Attends } \\
\text { school in winter. } \\
\text { Igo8. Has a fair } \\
\text { common school } \\
\text { education. In } \\
\text { good health. } \\
\text { Igog. This boy } \\
\text { is driving a milk } \\
\text { team for em- } \\
\text { ployer, and is } \\
\text { doing well. } \\
\text { x9ro. } \\
\text { People away on } \\
\text { visitor's call, } \\
\text { but neighbours } \\
\text { reported H. to } \\
\text { beearning good } \\
\text { wages; is driv- } \\
\text { ing a team. }\end{array}$ & $\begin{array}{l}\text { 1907. } \\
\text { Home satisfac- } \\
\text { tory. }\end{array}$ \\
\hline $\begin{array}{l}\stackrel{4}{\text { Mary }} \\
\text { C. } 1\end{array}$ & I5 & I8 & $\begin{array}{l}\text { Drunken im- } \\
\text { moral parents; } \\
\text { children filthy } \\
\text { from dirt and } \\
\text { vermin; very } \\
\text { ragged and } \\
\text { looked starved. } \\
\text { Father a fore- } \\
\text { man earning } \\
\text { 4os. (pays to- } \\
\text { wards support). } \\
\text { Father buys } \\
\text { clothes, which } \\
\text { the mother } \\
\text { pawns. }\end{array}$ & $\begin{array}{l}\text { rgo3. Spoken } \\
\text { most highly of. } \\
\text { Igo4. An excel- } \\
\text { lent reputation, } \\
\text { attends Sunday } \\
\text { S c h o o l a n d } \\
\text { Church. } \\
\text { 1905. Is in ser- } \\
\text { vice on her own } \\
\text { account; has a } \\
\text { most excellent } \\
\text { reputation. }\end{array}$ & $\begin{array}{l}\text { A good home; } \\
\text { good clothing } \\
\text { supplied. } \\
\text { Igo4. All cloth- } \\
\text { ing provided } \\
\text { a nd a f a ir } \\
\text { amount of poc- } \\
\text { ket-money. }\end{array}$ \\
\hline $\begin{array}{l}\text { 5. } \\
\text { Ruth } \\
\text { C.I }\end{array}$ & I4 & 19 & Ditto. & Satisfactory. & Home excellent. \\
\hline $\begin{array}{l}6 . \\
\text { Ethel } \\
\text { C. } 1\end{array}$ & 12 & I7 & Ditto. & Ditto. & $\begin{array}{l}\text { Treated as one } \\
\text { of the family. }\end{array}$ \\
\hline $\begin{array}{l}\text { Maud } \\
\text { C.1 }\end{array}$ & 7 & I3 & Ditto. & Ditto. & $\begin{array}{l}\text { Home excellent. } \\
\text { Treated as one } \\
\text { of the family. }\end{array}$ \\
\hline
\end{tabular}

1 Four sisters; the last not included in the statistics on account of youth. 
Types of Satisfactory Cases-(Continued).

\begin{tabular}{|c|c|c|c|c|c|}
\hline \multirow[b]{2}{*}{ Name. } & \multicolumn{2}{|c|}{ Age. } & \multirow[b]{2}{*}{$\begin{array}{l}\text { Previous } \\
\text { History. }\end{array}$} & \multirow[b]{2}{*}{ Record. } & \multirow{2}{*}{$\begin{array}{l}\text { Nature of } \\
\text { Home in } \\
\text { Canada. }\end{array}$} \\
\hline & $\begin{array}{l}\text { On Emi- } \\
\text { gration. }\end{array}$ & $\begin{array}{l}\text { On Ter- } \\
\text { mination } \\
\text { of } \\
\text { Record. }\end{array}$ & & & \\
\hline $\begin{array}{l}\text { 7. } \\
\text { Susan } \\
\text { P.1 }\end{array}$ & $x_{3}$ & $x 8$ & $\begin{array}{l}\text { Mother dead. } \\
\text { Father a drunk- } \\
\text { ard children } \\
\text { neglected and } \\
\text { verm in o u s. } \\
\text { F a ther pro- } \\
\text { secut ed by } \\
\text { N.S.P.C.C.; re- } \\
\text { ferred to as a } \\
\text { gross case. Sen- } \\
\text { tenced to three } \\
\text { months' hard } \\
\text { labour. Father } \\
\text { has lost five sit- } \\
\text { uations through } \\
\text { drink. }\end{array}$ & $\begin{array}{l}\text { rgo3. A good } \\
\text { report; attends } \\
\text { Sunday and day } \\
\text { school. Taught } \\
\text { t o play the } \\
\text { piano, and given } \\
\text { a bicycle; has } \\
\text { grown a very } \\
\text { lady-like girl. } \\
\text { t9o7. Girl is of } \\
\text { age and learn- } \\
\text { ing a tra de } \\
\text { still lives with } \\
\text { Mrs. J. }\end{array}$ & $\begin{array}{l}\text { Home excelient. } \\
\text { S. treated as a } \\
\text { daughter. }\end{array}$ \\
\hline $\begin{array}{l}\text { Eliza- } \\
\text { beth P.1 }\end{array}$ & 9 & 13 & Ditto. & Satisfactory. & A good home. \\
\hline Mary P.1 & 6 & $?$ & As above. & Ditto. & Good home. \\
\hline
\end{tabular}

\section{Types of Doubtful Cases.}

\begin{tabular}{|c|c|c|c|c|c|}
\hline $\begin{array}{l}8 . \\
\text { Thomas } \\
\text { H. }\end{array}$ & $\boldsymbol{x I}$ & 17 & $\begin{array}{l}\text { Illegitimate; par- } \\
\text { ents very poor ; } \\
\text { ill-treated by } \\
\text { step-father, who } \\
\text { drinks and is } \\
\text { cruel to the boy. } \\
\text { Mother delicate; } \\
\text { large family ; } \\
\text { boy trou ble- } \\
\text { some. }\end{array}$ & $\begin{array}{l}\text { r9o5. Tom is } \\
\text { going on nicely. } \\
\text { Feb. r9o5. Going } \\
\text { on well. } \\
\text { rgo6. Boy of low } \\
\text { intellect ; has, I } \\
\text { think, bad ten- } \\
\text { dencies. } \\
\text { rgog. This boy } \\
\text { has run away, } \\
\text { and is now liv- } \\
\text { ing with Mrs. } \\
\text { M.2 }\end{array}$ & $\begin{array}{l}\text { rgo3. Boy says } \\
\text { he has a first- } \\
\text { rate home. } \\
\text { rgo6. } \\
\text { Home satisfac- } \\
\text { tory. Boy not } \\
\text { as good as he } \\
\text { should be. }\end{array}$ \\
\hline
\end{tabular}

1 Three sisters; the last two not included in the statistics on account of youth.

2 This case was reported on by two different visitors. 
Types of Doubtful Cases-(Continued).

\begin{tabular}{|c|c|c|c|c|c|}
\hline \multirow[b]{2}{*}{ Name. } & \multicolumn{2}{|c|}{ Age. } & \multirow[b]{2}{*}{$\begin{array}{l}\text { Previous } \\
\text { History. }\end{array}$} & \multirow[b]{2}{*}{ Record. } & \multirow[b]{2}{*}{$\begin{array}{l}\text { Nature of } \\
\text { Home in } \\
\text { Canada. }\end{array}$} \\
\hline & $\begin{array}{l}\text { On Emi- } \\
\text { gration. }\end{array}$ & $\begin{array}{l}\text { On Ter- } \\
\text { mination } \\
\text { of } \\
\text { Record. }\end{array}$ & & & \\
\hline $\begin{array}{l}9 . \\
\text { Rachel } \\
\text { B. }\end{array}$ & ro & I7 & $\begin{array}{l}\text { Mother dead } 7 \\
\text { years. Father a } \\
\text { collier, drinks } \\
\text { several times in } \\
\text { prison as drunk } \\
\text { and disorderly. } \\
\text { Lodges with re- } \\
\text { la t iv es, n o } \\
\text { bedding, no fur- } \\
\text { niture. Father, } \\
\text { children, and } \\
\text { woman slept on } \\
\text { rags in place of } \\
\text { a bed; children } \\
\text { half starved, } \\
\text { ragged, and ver- } \\
\text { minous. Father } \\
\text { prosecuted by } \\
\text { N.S.P.C.C. and } \\
\text { convicted. }\end{array}$ & $\begin{array}{l}\text { I903. Reported } \\
\text { well and a good } \\
\text { child. } \\
\text { I } 904 \text {. C h il d } \\
\text { seems happy. } \\
\text { Igo6. Girl satis- } \\
\text { fied with home; } \\
\text { no desire to be } \\
\text { removed; at- } \\
\text { tends school ir- } \\
\text { regularly. }\end{array}$ & $\begin{array}{l}\text { rgo4. Poor home } \\
\text { and old people. } \\
\text { Igo6. Home un- } \\
\text { tidy. } \\
\text { rgo8. Poor home. } \\
\text { rgog. Below the } \\
\text { average. }{ }^{1}\end{array}$ \\
\hline
\end{tabular}

Types of Unsatisfactory Cases.

\begin{tabular}{|c|c|c|c|c|c|}
\hline $\begin{array}{l}\text { ro. } \\
\text { Henry } \\
\text { P. }\end{array}$ & I5 & 18 & $\begin{array}{l}\text { Illegitimate, } \\
\text { Mother dead, } \\
\text { boy placed out } \\
\text { at a baby-farm; } \\
\text { be c a me u n- } \\
\text { manageable; a } \\
\text { fresh home and } \\
\text { work found; } \\
\text { needed training. }\end{array}$ & $\begin{array}{l}\text { I902. "The boy } \\
\text { I got last spring } \\
\text { has proved more } \\
\text { than I could } \\
\text { manage; I have } \\
\text { tried to correct } \\
\text { him, but failed } \\
\text { to master him, } \\
\text { and abuse an-- } \\
\text { o th e r m a n's } \\
\text { child I cannot. } \\
\text { I am willing to } \\
\text { keep him and } \\
\text { s e n d h i m to } \\
\text { school all fall } \\
\text { and winter, and } \\
\text { do what I can } \\
\text { for hin for a }\end{array}$ & $\begin{array}{l}\text { I903. H. dis- } \\
\text { satisfied with } \\
\text { home. Removes } \\
\text { to P. J. in I903. } \\
\text { I } 904 \text {. In new } \\
\text { home, given to } \\
\text { telling lies, but } \\
\text { said he would } \\
\text { try to improve. } \\
\text { A strong healthy } \\
\text { boy. } \\
\text { I905. H. so bad } \\
\text { and unmanage- } \\
\text { able that he was } \\
\text { sent to Mrs. J.'s } \\
\text { son. Is of age } \\
\text { next month. }\end{array}$ \\
\hline - & & & \multicolumn{3}{|c|}{$\begin{array}{l}\text { I903. Mr. J. reports boy wonder- } \\
\text { fully improved, and thinks he will } \\
\text { be able to keep him. } \\
\text { 1903. Mr. J. complained about boy } \\
\text { being untruthful and generally bad. }\end{array}$} \\
\hline
\end{tabular}

1 Reported on by two different visitors. 
Types of Unsatisfactory Cases-(Continued).

\begin{tabular}{|c|c|c|c|c|c|}
\hline \multirow[b]{2}{*}{ Name. } & \multicolumn{2}{|c|}{ Age. } & \multirow[b]{2}{*}{$\begin{array}{l}\text { Previous } \\
\text { History. }\end{array}$} & \multirow[b]{2}{*}{ Record. } & \multirow{2}{*}{$\begin{array}{l}\text { Nature of } \\
\text { Home in } \\
\text { Canada. }\end{array}$} \\
\hline & $\begin{array}{l}\text { On Emi- } \\
\text { gration. }\end{array}$ & $\begin{array}{l}\text { On Ter- } \\
\text { mination } \\
\text { of } \\
\text { Record. }\end{array}$ & & & \\
\hline $\begin{array}{l}x \mathbf{x} . \\
\text { Albert } \\
\text { C. }\end{array}$ & 8 & 16 & $\begin{array}{c}\text { Mother a prosti- } \\
\text { tute. The man } \\
\text { she is now } \\
\text { living with was } \\
\text { sent to gaol for } \\
\text { six weeks with } \\
\text { hard labour for } \\
\text { ill-treating the } \\
\text { boy. Also fined } \\
\text { several times for } \\
\text { drunkenness. } \\
\\
\\
\text { rgo8. } \\
\text { roro. } \\
\text { neighb } \\
\text { Mr. D. } \\
\text { rities sh }\end{array}$ & $\begin{array}{l}\text { I } 905 . \mathrm{Mr} \text { r. D. } \\
\text { complains that } \\
\text { Albert is hard to } \\
\text { manage; goes } \\
\text { to school when } \\
\text { there is any, but } \\
\text { is not disposed } \\
\text { to learn. } \\
\text { go7. Boy im- } \\
\text { pudent and un- } \\
\text { manageable. } \\
\text { The re is no } \\
\text { school in the } \\
\text { district and no } \\
\text { prospect of any. } \\
\text { nnsatisfactory. } \\
\text { Reported as stealin } \\
\text { ourhood. A regul } \\
\text { anxious that th } \\
\text { hould take him in }\end{array}$ & $\begin{array}{l}\text { Home is very } \\
\text { humble, in an } \\
\text { in accessible } \\
\text { backward place. } \\
\text { T he D.'s a re } \\
\text { poor, and live } \\
\text { in a primitive } \\
\text { way. A mistake } \\
\text { to have settled } \\
\text { A l be rt w it h } \\
\text { them. In the } \\
\text { same home for } \\
7 \frac{1}{2} \text { years. } \\
\text { ng in the } \\
\text { lar devil. } \\
\text { hautho. } \\
\text { hand. }\end{array}$ \\
\hline $\begin{array}{l}\text { I2. } \\
\text { Hilda } \\
\text { G. }\end{array}$ & 10 & 17 & $\begin{array}{l}\text { Mother dead. } \\
\text { Father a drunk- } \\
\text { a rd, ou t of } \\
\text { work, and de- } \\
\text { serted his chil- } \\
\text { dren. }\end{array}$ & $\begin{array}{l}\text { 1902. Girl un- } \\
\text { truthful. } \\
\text { rgo3. is strong } \\
\text { H. is healthy, } \\
\text { and full of bad } \\
\text { but full } \\
\text { habits (report } \\
\text { of a d o p t e d } \\
\text { mother). } \\
\text { rgo6. There ap- } \\
\text { pe a r t o be } \\
\text { something the } \\
\text { matter with the } \\
\text { girl, as she will } \\
\text { lie down at any } \\
\text { time of the day } \\
\text { and go to sleep; } \\
\text { does not appear } \\
\text { very bright. } \\
\text { r9io. } \\
\text { Reportedstrong } \\
\text { and healthy. H. } \\
\text { very disobedi- } \\
\text { ent, untruthful, } \\
\text { and dirty ; no } \\
\text { change since } \\
\text { she came. }\end{array}$ & $\begin{array}{l}\text { Adopted mother } \\
\text { has been re- } \\
\text { ported for ill- } \\
\text { using the girl, } \\
\text { The visitor } \\
\text { thinks there is } \\
\text { no truth in the } \\
\text { report. } \\
\text { rgo6. Too many } \\
\text { young children } \\
\text { in this family. } \\
\end{array}$ \\
\hline
\end{tabular}


Records

Types of Unsatisfactory Cases-(Continued).

\begin{tabular}{|c|c|c|c|c|c|}
\hline \multirow[b]{2}{*}{ Name. } & \multicolumn{2}{|c|}{ Age. } & \multirow[b]{2}{*}{$\begin{array}{l}\text { Previous } \\
\text { History. }\end{array}$} & \multirow[b]{2}{*}{ Record. } & \multirow{2}{*}{$\begin{array}{l}\text { Nature of } \\
\text { Home in } \\
\text { Canada. }\end{array}$} \\
\hline & $\begin{array}{l}\text { On Emi- } \\
\text { gration. }\end{array}$ & $\begin{array}{l}\text { On Ter- } \\
\text { mination } \\
\text { of } \\
\text { Record. }\end{array}$ & & & \\
\hline $\begin{array}{l}\text { I3. } \\
\text { Elsie } \\
\text { M. }\end{array}$ & 12 & I7 & $\begin{array}{l}\text { Mother dead. } \\
\text { Father a lab- } \\
\text { ourer; married } \\
\text { a second time. } \\
\text { Girl be y ond } \\
\text { control and be- } \\
\text { fore the magis- } \\
\text { trates for theft. }\end{array}$ & $\begin{array}{l}\text { I903. Girl im- } \\
\text { p os s ible t o } \\
\text { manage, steals } \\
\text { and tells lies; } \\
\text { has a violent } \\
\text { temper. } \\
\text { I904. Girl is a } \\
\text { good worker, } \\
\text { but quarrelsome. } \\
\text { Igo6. Uneven } \\
\text { temper ; goes } \\
\text { to school. } \\
\text { I907. Girl is un- } \\
\text { satisfactory. } \\
\text { I908. In service. } \\
\text { I9o9. Girl has } \\
\text { been in } 4 \text { homes } \\
\text { since emigra- } \\
\text { tion; tendencies } \\
\text { are strongly im- } \\
\text { moral; keeps } \\
\text { improper com- } \\
\text { pany (visitor's } \\
\text { report). }\end{array}$ & $\begin{array}{l}\text { I } 903 . \text { F os ter } \\
\text { parents wish to } \\
\text { get rid of E. } \\
\text { r904. In fresh } \\
\text { home. Home } \\
\text { good. } \\
\text { I906. F r e s h } \\
\text { home; to be re- } \\
\text { moved. } \\
\text { rgo8. Fresh em- } \\
\text { ployer. H o m e } \\
\text { I909. Ho. } \\
\text { satisfactory. }\end{array}$ \\
\hline
\end{tabular}

\section{Remarks.}

It will be seen with regard to Records $4,5,6$, and 7 that these are exceptions to rule $b$ (page 17 , above), that a child admitted at a late age is likely to have an unsatisfactory record. The ages of these girls on admission were I5, I4, I2, and I 3 respectively, and their records are satisfactory. It may be thought that at 12 years it should not be too late to counteract the effects of a previous environment. But children of this class (Mr. Booth's Class A.) mature early, and more especially is this true with regard to the girls. 
If those who expect good results in the after career of a girl (or boy) admitted at the age of 12 , will pause to consider for a moment what the life of such a child has been previous to its admission, will picture its probable nightly sleeping accommodation, its probable daily associates, and the haunts of its parents, they will surely not be surprised to find, on reading later records, that many of the children classified as unsatisfactory or doubtful were admitted at the age of 12 .

Records 4, 5, 6, and 7, considered in the light of their previous history, seem singularly free from any hereditary taint.

I should class No. 9 as fairly satisfactory, because the record, although favourable as far as it goes, is so scanty; also the home being "untidy," and "below the average," it is not likely that the girl would attain to a very high standard of efficiency.

No. Io may be regarded as a hopeless case from the beginning ; admitted at the age of I 5 , and reported as unmanageable, there was little chance of his succeeding. It is possible that institutional training, with its discipline and regular routine, might have produced better results.

The unsatisfactory record of No. II is qualified by the nature of the home, which comes under condition $(c)$, clause I, on page I7. This home was in "an inaccessible place"; "there was no school in the district and no prospect of any," and "the people lived in a primitive way." The authorities acknowledged that it was a mistake to have settled the boy there.

With regard to No. 12, the adopted mother gives a bad account of the girl. On the other hand, the adopted mother has been herself reported for ill-using the child. The visitor, however, does not believe this report, but suggests that there are too many young children in this family.

One is reminded by these two last records and by No. 9 of 
the objection, always advanced by those not in favour of the boarding-out system, as to the difficulty of finding suitable homes. But, thanks to the care taken by the Y. Emigration authorities, both in placing out the children, and through their system of regular visiting, such homes are very much in the minority, if we may judge from these records.

No. I 3 was committed for theft, and has been accused of stealing since emigration. The record is bad. The sole extenuating circumstance seems to be that this girl was I2 on admission.

To sum up, four of the satisfactory cases, whose records I have given, might, in accordance with the conditions specified on page 17 , have been expected to turn out unsatisfactory; and three of the unsatisfactory cases are qualified by one or other of the same conditions. As will be seen on referring to page I9, the total number of unsatisfactory cases out of the 40 investigated was 4 .

\section{The Industrial School For Girls}

The lady from whose case-book I procured these records had been superintendent of this school for fifteen years; she left in 1910. During her superintendentship she kept continually in touch, as far as she was able, with all the girls who passed through the school; thus far exceeding the Home Office regulations, which require a report to be made upon each child up till the age of 18 -involving, that is, a two years' record only. Some of the longer records are of girls who left before her time, and of these unfortunately the records are scantier and no previous history is given.

With regard to the training of these girls, I quote from a letter sent to me on the subject by the lady in question.

" As at most Girls' Industrial Schools, the industrial training is mainly in the direction of the ordinary household needs, supplemented by technical classes on the same subjects, i.e. 
cooking, laundry, house and needle-work. The older girls are in school about half the time, and for the rest are at work under direction either in the kitchen, laundry, or workroom, or cleaning about the house.

"The girls have all the housework to do under the care of assistants, so they have ample opportunity for all varieties of domestic work, including house and parlourmaid work, in the superintendent's house.

"All the washing and needlework are done in the house, so that there is a large amount of practical work always at hand."

I went through 129 of the records. Of these:

80 were satisfactory.

27 were doubtful or only fairly satisfactory.

22 were unsatisfactory.

Of the 49 unsatisfactory or doubtful cases :

7 were definitely mental,

2 "almost deficient,"

I "hardly responsible,"

and I had an insane parent.

The average length of 74 of the 129 records of which I have copied the dates is IO.I years, 26 of these being kept ${ }^{1}$ for periods of more than Io years.

As the girls are committed to this school until the age of 16 , and only in very exceptional cases are discharged at 14 and I 5 , we may reckon the average age to which these 74 records are kept as 26.

It will be seen that the majority of these records are of girls employed in domestic service. To anyone having the most superficial knowledge of the "servant question," it will be apparent that the fact of a girl remaining for several years in the same place does not necessarily imply any very high standard of efficiency. There are mistresses who will put up with any imperfections rather than face the alternative

1 In some cases I find that I have omitted to enter the length of record; in others the final date was not given, though all conform to the 4 years' minimum. 


\section{Records}

of remaining servantless. It is also a fact that the really efficient and skilful servant is often possessed of undesirable morals, and that the girl who is honest and virtuous may, on the other hand, be totally incompetent.

Nevertheless, most of the satisfactory records which I have quoted seem to me to prove a real efficiency; some others, however, not quoted, contained remarks such as these: "Not a girl of great attainments, but kept her places steadily," "did fairly well in service, \&c." Now, the homes from which all these girls are taken were, with scarcely an exception, particularly bad ones. As I have said before, "efficiency" is a relative term; so that when I have found the child of a drunkard, or a prostitute, or a vagrant "doing fairly well in service," or "keeping her places steadily," I have classed her as satisfactory; she is at any rate no longer a member of Class A.

Most of these records date from 1896 onwards; there are some earlier ones to which I have already referred.

Types of Satisfactory Cases.

\begin{tabular}{|c|c|c|c|c|c|c|}
\hline Name. & 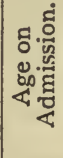 & 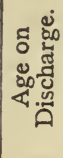 & $\begin{array}{l}\text { Previous } \\
\text { History. }\end{array}$ & Record. & 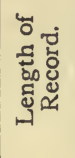 & 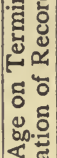 \\
\hline $\begin{array}{l}\text { I. } \\
\text { Mary } \mathrm{F} \text {. }\end{array}$ & ro & I6 & $\begin{array}{l}\text { Charged with not } \\
\text { being under pro- } \\
\text { per guardian- } \\
\text { ship. Mother a } \\
\text { prostitute and } \\
\text { indifferent to her } \\
\text { child. }\end{array}$ & $\begin{array}{l}\text { M. grew up a tall fine girl, not } \\
\text { very strong; did well as a cook, } \\
\text { earned good wages, much at- } \\
\text { tached to the school, returned } \\
\text { to help on several occasions; } \\
\text { was helpful in looking after } \\
\text { younger girls and keeping in } \\
\text { touch with them; spent holi- } \\
\text { days at the school for several } \\
\text { successive years. Has been } \\
\text { cook since rgo8 in a very good } \\
\text { family. }\end{array}$ & $\stackrel{7}{\text { years }}$ & 23 \\
\hline
\end{tabular}


Types of Satisfactory Cases-(Continued).

\begin{tabular}{|c|c|c|c|c|c|c|}
\hline Name. & 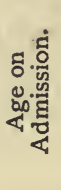 & 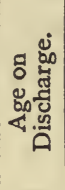 & $\begin{array}{l}\text { Previous } \\
\text { History. }\end{array}$ & Record. & 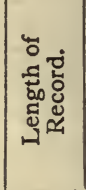 & 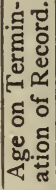 \\
\hline Alice B. & II & $\begin{array}{c}1907 \\
16\end{array}$ & $\begin{array}{l}\text { Sent by London } \\
\text { School Board, } \\
\text { charged with } \\
\text { w a nd r ring. } \\
\text { Mother dead; } \\
\text { father poor and } \\
\text { drunken, took } \\
\text { no notice of } \\
\text { child. Brother } \\
\text { sent to the } \\
\text { Shaftesbury. }\end{array}$ & $\begin{array}{l}\text { A. grew up a fine bonny girl, } \\
\text { capable and much attached } \\
\text { to the school. Began service } \\
\text { as between maid. } \\
\text { Ap. Igo9. Went as scullery maid } \\
\text { to a house where many ser- } \\
\text { vants kept. Means to work } \\
\text { her way up; works under a } \\
\text { chef who helps her. } \\
\text { I908, I9Ir. At Old Girls' party. } \\
\text { Wages fr8. } \\
\text { I908, I909, I9Io. Spent holiday } \\
\text { at the school. } \\
\text { I912. In a very good situation. }\end{array}$ & years & $2 \mathrm{I}$ \\
\hline $\begin{array}{l}\text { Flor- } \\
\text { ence } M .\end{array}$ & 8 & $\begin{array}{l}\text { I90I } \\
\text { I6 }\end{array}$ & $\begin{array}{l}\text { Sent by County } \\
\text { Council charg- } \\
\text { ed with destitu- } \\
\text { tion; is an or- } \\
\text { phan; had been } \\
\text { cruelly treated } \\
\text { by an older } \\
\text { sister. }\end{array}$ & $\begin{array}{l}\text { Began service as scullery maid } \\
\text { at Orphan Asylum. } \\
\text { r9o2. Was promoted to kitchen } \\
\text { maid. The matron reports her } \\
\text { as "very sensible." } \\
\text { r903. Left the Orphan Asylum } \\
\text { and went to Poor Law } \\
\text { School. } \\
\text { r9o5 to I9ro. At Workhouse as } \\
\text { assistant labour mistress; is fill- } \\
\text { ing a responsible position well. } \\
\text { A tall, fine-looking young wo- } \\
\text { man, interested in her work } \\
\text { and thoroughly capable. At } \\
\text { Old Girls' Party in r903, 'og, 'Io } \\
\text { and 'Ir. } \\
\text { rgog. Spent a holiday at the } \\
\text { school. } \\
\text { r9rr. Visited her and saw over } \\
\text { workhouse, had tea in her } \\
\text { room. Wages } £ 26 \text {. }\end{array}$ & \begin{tabular}{|c|} 
ro \\
years
\end{tabular} & 26 \\
\hline K. & 8 & $\begin{array}{c}1893 \\
16\end{array}$ & Not given. ${ }^{1}$ & $\begin{array}{l}\text { Became an excellent kitchen } \\
\text { maid, and later cook. } \\
\text { 1 } 899 \text { to rgoo. Kitchen maid at a } \\
\text { great hcuse. Married well. } \\
\text { rgrr. At Oid Girls' Party with } \\
\text { her little girl. } \\
\text { rgra. Ditto. }\end{array}$ & $\begin{array}{c}\text { 19 } \\
\text { years }\end{array}$ & 35 \\
\hline
\end{tabular}

1 This girl left before the superintendent's time. 
Types of Satisfactory Cases-(Continued).

\begin{tabular}{|c|c|c|c|c|c|c|}
\hline Name. & 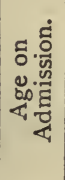 & 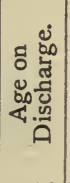 & $\begin{array}{l}\text { Previous } \\
\text { History. }\end{array}$ & Record. & 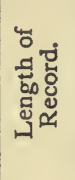 & 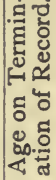 \\
\hline $\begin{array}{l}\text { M. } \\
\text { F. }\end{array}$ & 6 & $\begin{array}{c}1893 \\
16\end{array}$ & Not given. ${ }^{1}$ & $\begin{array}{l}\text { Delicate and rather deaf, but } \\
\text { had excellent places. Return- } \\
\text { ed to the school as cook. } \\
\text { Jan. I903-4. Married a groom, } \\
\text { lives in comfortable rooms in } \\
\text { West End. } \\
\text { I9Ir. At Old Girls' Party. }\end{array}$ & $\begin{array}{c}17 \\
\text { years }\end{array}$ & 33 \\
\hline $\begin{array}{l}6 . \\
\text { Edith I. }\end{array}$ & Io & 16 & Not given. ${ }^{2}$ & $\begin{array}{l}\text { A dependable, reliable woman, } \\
\text { much attached to the school. } \\
\text { For many years at an Embassy. } \\
\text { Frequently visited the school } \\
\text { in holidays, and regularly sub- } \\
\text { scribed to it. } \\
\text { I9ro. Went as cook to one of } \\
\text { the Secretaries of Legation. }\end{array}$ & $\begin{array}{c}28 \\
\text { years }\end{array}$ & 44 \\
\hline Jane D. & 13 & $\begin{array}{c}1886 \\
16\end{array}$ & Not given. ${ }^{3}$ & $\begin{array}{l}\text { A rough, awkward girl, but with } \\
\text { lots of determination which en- } \\
\text { abled her to qualify herself as } \\
\text { trained midwife and nurse. } \\
\text { Has a comfortable home of her } \\
\text { own in the country where she is } \\
\text { district nurse. } \\
\text { I9ro. Visited the school. }\end{array}$ & $\begin{array}{c}26 \\
\text { years }\end{array}$ & $3^{8}$ \\
\hline
\end{tabular}

Types of Doubtful Cases.

\begin{tabular}{|c|c|c|c|c|c|}
\hline \multirow[t]{2}{*}{$\begin{array}{l}8 . \\
\text { Mary F. } \\
\text { (Mental } \\
\text { causes.) }\end{array}$} & \multirow[t]{2}{*}{$\begin{array}{c}1899 \\
16\end{array}$} & $\begin{array}{l}\text { Charged with } \\
\text { "found wan- } \\
\text { dering :" mother } \\
\text { in prison } 6 \\
\text { months for ne- } \\
\text { glect of children. } \\
\text { Father a suicide. } \\
\text { Parents previ- } \\
\text { ously separated. }\end{array}$ & $\begin{array}{l}\text { An intelligent, superior girl, sub- } \\
\text { ject to fits of hysteria, during } \\
\text { which she was unconscious for } \\
\text { hours. When normal had a } \\
\text { keen imagination and wrote } \\
\text { rhymes. Did not settle well in } \\
\text { service, probably had fits. The } \\
\text { following year was found wan- } \\
\text { dering. Wrote extraordinary } \\
\text { letters. At I8 learnt type- }\end{array}$ & $\begin{array}{c}\text { 1o } \\
\text { years }\end{array}$ & \multirow[t]{2}{*}{26} \\
\hline & & $\begin{array}{l}\text { writin } \\
\text { cation } \\
\text { home } \\
\text { her ar } \\
\text { rgog. }\end{array}$ & $\begin{array}{l}g \text { and entered an office improved } \mathrm{i} \\
\mathrm{a} \text { and did well ; made a neat and } \\
\text { and visited the school frequently. } \\
\mathrm{rm} \text { and health failed. Sight affect } \\
\text { Badly off and unable to do much }\end{array}$ & $\begin{array}{l}\text { n edu- } \\
\text { dainty } \\
\text { Broke } \\
\text { ted. } \\
\text { a. }\end{array}$ & \\
\hline
\end{tabular}

1 Sister to No. 4.

2 Left previous to 1896 .

3 Left before the superintendent's time. 
Types of Doubtful Cases-(Continued).

\begin{tabular}{|c|c|c|c|c|c|c|}
\hline Name. & 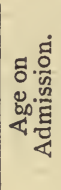 & 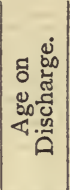 & $\begin{array}{l}\text { Previous } \\
\text { History. }\end{array}$ & Record. & 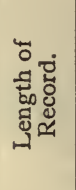 & 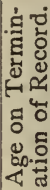 \\
\hline $\begin{array}{l}\text { 9. } \\
\text { Maria P } \\
\text { (Mental } \\
\text { causes). }\end{array}$ & 5 & $\begin{array}{c}\mathrm{I} 898 \\
\mathrm{I} 5\end{array}$ & $\begin{array}{l}\text { Charged with } \\
\text { "found wand- } \\
\text { ering." Mother } \\
\text { bad, no home. } \\
\text { Child born in } \\
\text { Holloway Gaol ; } \\
\text { lost herself sell- } \\
\text { ing matches. }\end{array}$ & $\begin{array}{l}\text { A little wizened old woman, } \\
\text { charmed with new surround- } \\
\text { ings, never got over early } \\
\text { neglect, always dwarfed and } \\
\text { dull; apprenticed to a dress- } \\
\text { maker, could sew well; was } \\
\text { not found reliable, changed } \\
\text { her places frequently. Poor } \\
\text { health. Decidedly weak- } \\
\text { minded at I7. }\end{array}$ & $\begin{array}{c}3 \\
\text { years }\end{array}$ & 18 \\
\hline $\begin{array}{l}\text { ro. } \\
\text { Hannah } \\
\text { Y. }\end{array}$ & II & $\begin{array}{c}1901 \\
16\end{array}$ & $\begin{array}{l}\text { Sent by School } \\
\text { Board, charged } \\
\text { with being un- } \\
\text { controllable; } \\
\text { girl has a sullen } \\
\text { dogged look; } \\
\text { says her step- } \\
\text { mother was } \\
\text { cruel to her, so } \\
\text { she ran away } \\
\text { and slept on the } \\
\text { beach. }\end{array}$ & $\begin{array}{l}\text { A melancholy-looking, sullen- } \\
\text { faced girl. Health soon failed } \\
\text { in service (Chronic ulceration } \\
\text { of the stomach). Had several } \\
\text { places between times in Hos- } \\
\text { pital up to I907, when she } \\
\text { went to M- Infirmary and } \\
\text { remained there. Writes grate- } \\
\text { fully occasionally. } \\
\text { I903. At Old Girls' Party. } \\
\text { I904. Spent holiday at the } \\
\text { school. } \\
\text { rgro. Confined to bed in In- } \\
\text { firmary; has tuberculosis of the } \\
\text { spine. } \\
\text { rgII. Better report. }\end{array}$ & $\begin{array}{c}\text { ro } \\
\text { years }\end{array}$ & 26 \\
\hline
\end{tabular}

\section{Types of Unsatisfactory Cases.}

\begin{tabular}{|c|c|c|c|c|c|c|}
\hline $\begin{array}{l}\text { Ir. } \\
\text { Ethel S. }\end{array}$ & Io & I6 & $\begin{array}{l}\text { Sent by County } \\
\text { Council, charg- } \\
\text { ed with pilfer- } \\
\text { ing and being } \\
\text { uncontrollable. } \\
\text { Lived with } \\
\text { father and } \\
\text { grandmother } \\
\text { after her } \\
\text { mother's death. } \\
\text { Grandmother } \\
\text { had no control. }\end{array}$ & $\begin{array}{l}\text { A big, strong, rough girl who } \\
\text { stammered. Placed in service } \\
\text { as laundry-maid. Unsteady } \\
\text { and untrustworthy. Is only } \\
\text { safe under strict control. Was } \\
\text { in House of Mercy for } 2 \\
\text { years. Later, Igro, admitted } \\
\text { to L. Home, finally moved } \\
\text { to D- to a home specially } \\
\text { for girls who fail in service. } \\
\text { "Ethel is too morally deficient } \\
\text { to be safe anywhere but under } \\
\text { protection." A good hand at } \\
\text { laundry work. } \\
\text { Oct. Igro. Made head-laundry } \\
\text { girl at the Home, hopes "to } \\
\text { be a help to them all." } \\
\text { rgri. Ditto. } \\
\text { Ap. I9ri. Made a matron. }\end{array}$ & $\begin{array}{c}6 \\
\text { years }\end{array}$ & 22 \\
\hline
\end{tabular}


Types of Unsatisfactory Cases-(Continued).

\begin{tabular}{|c|c|c|c|c|c|c|}
\hline Name. & 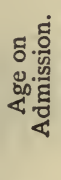 & 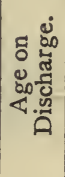 & $\begin{array}{l}\text { Previous } \\
\text { History. }\end{array}$ & Record. & 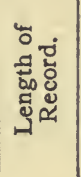 & 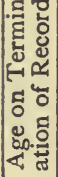 \\
\hline $\begin{array}{l}\text { I2. } \\
\text { Jane } 0 .\end{array}$ & 12 & r6 & $\begin{array}{l}\text { Com m it t ed } \\
\text { by Borough, } \\
\text { charged with } \\
\text { immoral sur- } \\
\text { round i n g s. } \\
\text { Father dead; } \\
\text { mother in work- } \\
\text { house. }\end{array}$ & $\begin{array}{l}\text { A réfined-looking girl but with } \\
\text { little character; was giddy and } \\
\text { fast, "probably inherited from } \\
\text { her mother, who was bad." } \\
\text { The school made little impres- } \\
\text { sion on her. Last heard of } \\
\text { rg07, when she was discharged } \\
\text { from Union. }\end{array}$ & $\begin{array}{c}8 \\
\text { years }\end{array}$ & 24 \\
\hline $\begin{array}{l}\text { I3. } \\
\text { Kate J. } \\
\text { (Mental } \\
\text { causes.) }\end{array}$ & 10 & $\begin{array}{c}1899 \\
x 6\end{array}$ & $\begin{array}{l}\text { Charged with } \\
\text { "found wand- } \\
\text { ering." Mother } \\
\text { dead, c h il d } \\
\text { neglected. }\end{array}$ & $\begin{array}{l}\text { An undersized, unresponsive } \\
\text { girl. When in service she } \\
\text { gave trouble with a sulky bad } \\
\text { temper. Returned to London } \\
\text { to be near her friends. } \\
\text { r9o2. At the age of rg was } \\
\text { taken to workhouse, having } \\
\text { developed epilepsy. Reported } \\
\text { as a confirmed epileptic. Not } \\
\text { likely to be able to earn her } \\
\text { living. } \\
\text { Dec. I9O2. Committed to Epi- } \\
\text { leptic Colony at T-. }\end{array}$ & $\begin{array}{c}3 \\
\text { years }\end{array}$ & 19 \\
\hline $\begin{array}{l}\text { I4. } \\
\text { Const- } \\
\text { ance D. }\end{array}$ & 7 & $\begin{array}{c}1899 \\
16\end{array}$ & $\begin{array}{l}\text { Charged with } \\
\text { neglect. Father } \\
\text { a wretched man } \\
\text { with distorted } \\
\text { f e a t u res, of } \\
\text { whom the girl } \\
\text { was ashamed } \\
\text { and afraid; he } \\
\text { was immoral } \\
\text { and scarcely re- } \\
\text { sponsible. }\end{array}$ & $\begin{array}{l}\text { C. was a quiet, nice-looking } \\
\text { girl; no moral character, could } \\
\text { not be prevented attracting the } \\
\text { attention of men. } \\
\text { rgoo. Admitted to workhouse } \\
\text { at I7. Her child was born in } \\
\text { workhouse. } \\
\text { 1903. Sent to Home for } \\
2 \text { years. } \\
\text { rgo5. Returned to service and } \\
\text { remained there } 5 \text { years. At } \\
\text { Old Girls' Party for } 5 \text { con- } \\
\text { secutive years. Spent a holi- } \\
\text { day at the school; influence } \\
\text { undesirable. }\end{array}$ & $\begin{array}{c}12 \\
\text { years }\end{array}$ & 28 \\
\hline
\end{tabular}


Types of Unsatisfactory Cases-(Continned).

\begin{tabular}{|c|c|c|c|c|c|c|}
\hline Name. & 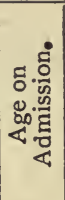 & 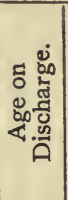 & $\begin{array}{l}\text { Previous } \\
\text { History. }\end{array}$ & Record. & 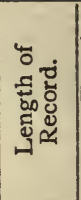 & 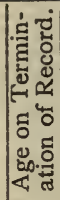 \\
\hline $\begin{array}{l}\text { I5. } \\
\text { Alice S. }\end{array}$ & 12 & $\begin{array}{c}1905 \\
16\end{array}$ & $\begin{array}{l}\text { Charged with } \\
\text { "found beg- } \\
\text { ging." Parents } \\
\text { deaf and dumb } \\
\text { tramps. Chil- } \\
\text { dren tramped, } \\
\text { sleeping out in } \\
\text { common lodg- } \\
\text { ing - h o u s es. } \\
\text { Girl a regular } \\
\text { sturdy beggar, } \\
\text { with no regard } \\
\text { for truth. }\end{array}$ & $\begin{array}{l}\text { A strong sturdy girl of very low } \\
\text { type, not fit for service to have } \\
\text { her liberty ; was placed in a } \\
\text { Home; unable to be kept } \\
\text { owing to bad influence and } \\
\text { rudeness. Tried in other } \\
\text { Homes. } \\
\text { rgro. At } 21 \text { reported as in } \\
\text { workhouse. Home to stay } 2 \\
\text { rgrr. In X. How. Is very naughty. } \\
\text { years. In }\end{array}$ & $\begin{array}{c}6 \\
\text { years }\end{array}$ & 22 \\
\hline $\begin{array}{l}\text { I6. } \\
\text { Lilian B. }\end{array}$ & II & $\begin{array}{c}1906 \\
16\end{array}$ & $\begin{array}{l}\text { Charged with } \\
\text { living with pro- } \\
\text { stitutes. Father } \\
\text { an army pen- } \\
\text { sioner, who de- } \\
\text { serted his wife. } \\
\text { Mother's char- } \\
\text { acter bad. }\end{array}$ & $\begin{array}{l}\text { A big strong girl, rather stupid, } \\
\text { not a bad girl at school, but } \\
\text { morally uncontrolled, gave } \\
\text { endless trouble in various } \\
\text { places by her infatuation for } \\
\text { men. } \\
\text { rgo6. Confined in Lock Hos- } \\
\text { pital. Replaced in service, } \\
\text { ran away at once and lost } \\
\text { sight of for months, and re- } \\
\text { turned to Lock Hospital. Two } \\
\text { years later in the workhouse, } \\
\text { and later, rgro, sent for } 2 \text { years } \\
\text { to House of Mercy. } \\
\text { Igr. Not fit to be at liberty. }\end{array}$ & $\begin{array}{c}5 \\
\text { years }\end{array}$ & $2 \mathrm{I}$ \\
\hline $\begin{array}{l}\text { I7. } \\
\text { Grace E. } \\
\text { (Mental } \\
\text { causes.) }\end{array}$ & I2 & $\begin{array}{c}1904 \\
16\end{array}$ & $\begin{array}{l}\text { Charged with } \\
\text { w a d d e ring. } \\
\text { F a ther and } \\
\text { child living with } \\
\text { child's grand- } \\
\text { mother; child } \\
\text { charged with } \\
\text { stealing along } \\
\text { with another } \\
\text { girl. Very thin } \\
\text { and peevish. } \\
\text { F a ther died } \\
\text { I904. }\end{array}$ & $\begin{array}{l}\text { Grew up a tall, discontented } \\
\text { girl, not reliable; did little } \\
\text { good in service, constantly } \\
\text { changing, and very fighty and } \\
\text { unsteady. } \\
\text { x9o8. At Old Girls' Party. } \\
\text { rgog. Admitted to penitentiary } \\
\text { for } 2 \text { years at House of Mercy. } \\
\text { Oct. rgog. Had been expelled, } \\
\text { and was reported as subse- } \\
\text { quently in an insane asylum, } \\
\text { and later in a Church Army } \\
\text { Home. }\end{array}$ & $\begin{array}{c}5 \\
\text { years }\end{array}$ & $2 \mathrm{I}$ \\
\hline
\end{tabular}


Types of Unsatisfactory Cases-(Continued).

\begin{tabular}{|c|c|c|c|c|c|}
\hline Name. & 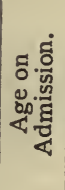 & 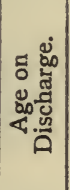 & $\begin{array}{l}\text { Previous } \\
\text { History. }\end{array}$ & Record. & 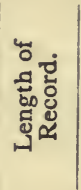 \\
\hline $\begin{array}{l}x 8 . \\
\text { Hannah } \\
\text { O. }\end{array}$ & II & $\begin{array}{c}\mathrm{x} 900 \\
\mathrm{x}_{4}\end{array}$ & $\begin{array}{l}\text { Charged with } \\
\text { stealing. A wil- } \\
\text { ful, sullen child } \\
\text { who had been } \\
\text { badly treated. } \\
\text { Mother dead; } \\
\text { father a con- } \\
\text { sumptive who } \\
\text { died later. }\end{array}$ & $\begin{array}{l}\text { Was transferred to Industrial } \\
\text { School, where they also found } \\
\text { her "deceitful beyond descrip- } \\
\text { tion" ; constantly tampered } \\
\text { with locks and keys, and had } \\
\text { times of rebellion. } \\
\text { I903. Returned to her grand- } \\
\text { mother. } \\
\text { I905. In Infirmary ill. } \\
\text { I906. When last heard of, was } \\
\text { wanted by police on a charge } \\
\text { of stealing ; had left her place } \\
\text { and could not be traced. }\end{array}$ & $\begin{array}{c}5 \\
\text { years }\end{array}$ \\
\hline
\end{tabular}

\section{Remarks.}

There seems little to say about most of these records; they speak for themselves.

With regard to Nos. $4,5,6$, and 7 , where the history is not given, these girls left before 1896, the year when the superintendent took charge of the school. It is not likely that if recorded their previous history would have been better than that of the average case.

As to the doubtful cases: the father of No. 8 was a suicide, and she herself was subject to fits; the facts seem to point to the probability of an inherited taint. This girl was intelligent and superior; she learnt typewriting, "and made herself a neat and dainty home"; finally, however, her health failed, and she was unable to do much. It seems almost callous to suggest with regard to a career that held so many promising features, that here after all was one "of many (cases) who, although they contribute materially to their own 
livelihood, would be better if under permanent custodial treatment." 1

No. 9 was " decidedly weak-minded." No. I I is an example of a morally deficient girl doing well when subjected to special treatment and segregation.

As to the unsatisfactory cases: with regard to No. 12, the superintendent suggests " that this girl's immorality" was "probably inherited from her mother, who was bad!" On the other hand, she was admitted at the age of twelve, and had "previously lived in immoral surroundings." No. I 3 was an epileptic. No. I4 "had no moral character"; the father was also immoral and "hardly responsible." I have not classed this as a mental case, but it seems probable.

The history and record of No. I 5 are, I think, pathetic. The parents of this child were deaf and dumb; they were also vagrants who tramped the country-side, so that not only was the child shut out from the advantages of treatment in the Special Schools, but she was cut off also from the ordinary common-school education of the normal slum child. It is impossible to think of a case as normal which possessed such an abnormal history, but I have not classified it as mental.

With regard to No. 16, I suppose this would be quoted by the Eugenists as a clear case of inherited vice. On the other hand, might not the disadvantages involved in admission at the age of twelve apply almost equally to the age of eleven? It does not seem fair to imply that this is a clear case of heredity, when the child during the most impressionable years of its life had been living with prostitutes.

I have purposely quoted a fair number of these doubtful and unsatisfactory cases, in order to illustrate the kind of failings which appear most prevalent. Many of these unsatisfactory cases I would class as " moral defectives"-people who, to quote the definition given by Sir James Crichton Browne, " have by reason of disease or disorder of the brain, undergone

1 Report of the Royal Commission on the Care and Control of the Feeble-Minded, Part III, p. 9 . 
a change of character, manifested in a course of vicious or criminal conduct without obvious impairment of intellect." ${ }^{1}$

Such cases "are greatly wanting in initiative, and are easily influenced by others; their moral sense is very defective, and they have little self-control or power to resist temptation when it comes in their way. They are frequently in trouble for breaking the law, and it is difficult to know what to do with them. By their proneness to commit larceny, arson, indecent assaults, \&c., they are a constant source of annoyance, expense, and danger. Many of them are quite unfit, if left to themselves, to lead decent, inoffensive lives; they require care and discipline, \&c." 2

It would be ridiculous to argue that all these girls who have failed morally have necessarily some mental taint. I would only suggest in cases which are persistent and ungovernable that it might be possible, if the family history were carefully investigated, to find something of the sort to account for it.

And with regard to the standard of conduct exacted from the woman, as compared to that exacted from the man, it is already clearly fixed by social use and custom. The man's private morality, if he be an efficient workman, is little called in question; the woman's, more particularly if she be engaged in domestic service, it is impossible to dissociate from her general efficiency. And certainly I have generally found in these records that the efficient servant has also a quite satisfactory moral character.

\section{The Industrial School For Boys (No. I)}

This is one of the larger Industrial Schools, and accommodates 150 boys. They are trained in tailoring, shoemaking, gardening, woodwork, metal work, gymnastics, rifle-shooting, and band practice. "Of 73 boys who are 13 years of age or over, 43 are regularly engaged in skilled occupations, and

1 Report of the Royal Commission on the Care and Control of the Feeble-Minded, 1908, Part III, p. Igo.

2 Ibid., p. II7. 
I 4 others are so engaged during partial time. Forty-one boys have left the school during the past year, and all but one have entered skilled or progressive occupations. No less than 3I have gone to farm-work. All but two of the situations were found by the school." 1

Of records I have only a small number. The school was awkwardly situated, so that much time was spent in going and coming. I also found it difficult to procure records which had been kept for any length of time, many of them stopping at the age of 18 . This is the regulation time appointed by the Government, and after that age there is no compulsion for records to be kept.

I originally got 33 of these records. Unfortunately half of them were accidentally burnt, so that I am unable to give the number of satisfactory or unsatisfactory cases out of the whole number, but only out of the 16 which remain. ${ }^{2}$

I regard these records as less carefully kept than most. The information given was in many cases so scanty that it was often most difficult to classify them properly; and I think had I been able to take a larger number of cases there would have been a higher proportion of unsatisfactory records than in those of the other homes. This I judged from turning over the pages of the disposal books and seeing the word " reconvicted " occur pretty frequently in the record column.

The report on this school by the Government inspector for I9I0 was quite satisfactory.

Of these 16 records

I I were satisfactory.

2 were doubtful.

3 were unsatisfactory.

The average length of record was 5 years.

The average age to which 12 of these 16 records were kept was 20 years 6 months.

1 Report of the Inspector of Reformatory and Industrial Schools, 19ro.

2 I have not counted the 33 in the 295 cases investigated, but only the 16 . 
Types of Satisfactory Cases.

\begin{tabular}{|c|c|c|c|c|c|c|}
\hline Name. & 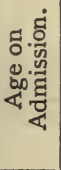 & 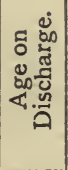 & $\begin{array}{l}\text { Previous } \\
\text { History. }\end{array}$ & Record. & 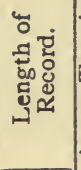 & 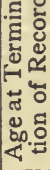 \\
\hline $\begin{array}{l}\text { I. } \\
\text { Henry T. }\end{array}$ & 12 & $\begin{array}{c}1898 \\
15\end{array}$ & $\begin{array}{l}\text { Charged with } \\
\text { frequenting the } \\
\text { company of } \\
\text { thi'eves; not } \\
\text { under proper } \\
\text { guardianship; } \\
\text { previouscharac- } \\
\text { ter bad. Father } \\
\text { a labourer, now } \\
\text { in gaol, await- } \\
\text { ing trial on two } \\
\text { charges of "re- } \\
\text { ceiver of stolen } \\
\text { goods." }\end{array}$ & $\begin{array}{l}\text { r898. In situation as page boy } \\
\text { to a doctor. } \\
\text { r } 899 \text {. Satisfactory in every way } \\
\text { employed later by Cycle Co. } \\
\text { as frame finisher. } \\
\text { rgo5. Employed by National } \\
\text { Telephone Co. at 24s. a week. }\end{array}$ & $\begin{array}{c}7 \\
\text { years }\end{array}$ & 22 \\
\hline $\begin{array}{l}2 . \\
\text { George } \\
\text { P. }\end{array}$ & 12 & $\begin{array}{c}1903 \\
16\end{array}$ & $\begin{array}{l}\text { Non-compliance: } \\
\text { with attendance } \\
\text { order. Boy il- } \\
\text { legitimate. }\end{array}$ & $\begin{array}{l}\text { April 1903. On a farm in Wales. } \\
\text { Oct. 1903. Doing well. } \\
\text { Dec. 1903. Doing well. } \\
\text { 1905. Doing well. } \\
\text { 1906. Changed employment. } \\
\text { 1910. Employed as a miner. } \\
\text { Appears to be doing well. }\end{array}$ & $\begin{array}{c}7 \\
\text { years }\end{array}$ & 23 \\
\hline
\end{tabular}

Types of Doubtful or only Fairly Satisfactory Cases.

\begin{tabular}{|c|c|c|c|c|c|c|}
\hline J. John E. & 12 & $\begin{array}{c}1899 \\
\times 5\end{array}$ & $\begin{array}{l}\text { Charged with } \\
\text { begging; par- } \\
\text { ents' character } \\
\text { bad; they send } \\
\text { their children } \\
\text { out to beg, and } \\
\text { are about to be } \\
\text { prosecuted by } \\
\text { the N.S.P.C.C. } \\
\end{array}$ & $\begin{array}{l}\text { r899. Employed as picture- } \\
\text { frame maker at } 8 s . \\
\text { Feb. I899. Report good. } \\
\text { Igoo. Visited school ; is em- } \\
\text { ployed as blacksmith's labourer } \\
\text { at gs. } \\
\text { June rgoo. As liftman at r4s. } \\
\text { rgor. As liftman with a fresh } \\
\text { firm at } 30 s \text {. } \\
\text { r903. As timekeeper with same } \\
\text { firm. Visited school. } \\
\text { r903. Vo. In hospital with enteric ; } \\
\text { r908. In } \\
\text { previous to this was a soldier } \\
\text { in India for } 2 \frac{1}{2} \text { years. Was in } \\
\text { army for } 3 \text { years. Is now out } \\
\text { of work. }\end{array}$ & $\stackrel{9}{\text { years }}$ & 24 \\
\hline
\end{tabular}


Types of Doubtful or only Fairly Satisfactory Cases-(Continued).

\begin{tabular}{|c|c|c|c|c|c|c|}
\hline Name. & 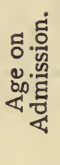 & 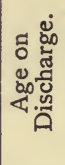 & $\begin{array}{c}\text { Previous } \\
\text { History. }\end{array}$ & Record. & 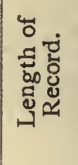 & 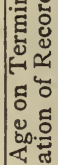 \\
\hline $\begin{array}{l}\text { We } \\
\text { T. }\end{array}$ & 7 & $\begin{array}{c}1903 \\
\mathrm{x}_{4}\end{array}$ & $\begin{array}{l}\text { Charged with } \\
\text { destitution, pre- } \\
\text { vious character } \\
\text { good. Father a } \\
\text { butcher under- } \\
\text { going } 3 \text { months' } \\
\text { imprisonment } \\
\text { for cruelty and } \\
\text { neglect of his } \\
\text { family. Mother } \\
\text { dead. }\end{array}$ & $\begin{array}{l}\text { Employed at barracks as band } \\
\text { boy. } \\
\text { I803. Letter asking for bank } \\
\text { money. } \\
\text { r903. Sailed for S. Africa. } \\
\text { 1904 and r905. At Gosport. } \\
\text { 1906. Letter asking for bank } \\
\text { money. Invalided home with } \\
\text { tubercular hip. } \\
\text { r907. In Convalescent Home. }\end{array}$ & $\begin{array}{c}5 \\
\text { years }\end{array}$ & 19 \\
\hline Jack U. & I2 & $\begin{array}{c}1905 \\
16\end{array}$ & $\begin{array}{l}\text { Charged with } \\
\text { not being under } \\
\text { proper guard- } \\
\text { ianship. Father } \\
\text { a bricklayer, } \\
\text { a ddress un- } \\
\text { known. Father } \\
\text { c onvicted of } \\
\mathrm{t} \text { h e ft, and } \\
\text { mother reported } \\
\text { as no fit guar- } \\
\text { dian for the boy. }\end{array}$ & $\begin{array}{l}\text { I905. Employed as messenger } \\
\text { boy to bootmaker at } 4 s .6 d \text {. } \\
\text { 1905. Employed at a dye works } \\
\text { at } 6 \text { s. } \\
\text { I906. At a brick-yard at from } \\
\text { I2s. to } 3 \text { s. } \\
\text { I908. Out of work and con- } \\
\text { victed for sleeping out.1 }\end{array}$ & $\begin{array}{c}3 \\
\text { years }\end{array}$ & I9 \\
\hline
\end{tabular}

Types of Unsatisfactory Cases.

\begin{tabular}{|c|c|c|c|c|c|c|}
\hline $\begin{array}{l}6 . \\
\text { Peter F. }\end{array}$ & I0 & $\begin{array}{c}1903 \\
15\end{array}$ & $\begin{array}{l}\text { Beyond parent's } \\
\text { control. Illegi- } \\
\text { timate. Father } \\
\text { has been paying } \\
3^{s} \text {. a week to- } \\
\text { wards child's } \\
\text { maintenance. }\end{array}$ & $\begin{array}{l}\text { 1904. Working as a tailor; } \\
\text { good report. } \\
\text { rgo5-rgo6. Unknown. } \\
\text { rgo8. Letter from Master of } \\
\text { workhouse stating that P. is } \\
\text { an inmate. }\end{array}$ & $\begin{array}{c}5 \\
\text { years }\end{array}$ & 20 \\
\hline James G. & II & $\begin{array}{c}1905 \\
14\end{array}$ & $\begin{array}{l}\text { Charged with } \\
\text { felony. Parents } \\
\text { dead. }\end{array}$ & $\begin{array}{l}\text { I905. Employed as under- } \\
\text { groom. } \\
\text { I905. Left this post. Visited } \\
\text { school. Employed as groom } \\
\text { gardener. } \\
\text { Igo6. Working as a collier in } \\
\text { Wales. } \\
\text { Igo8. Convicted of stealing } £ 5 \\
\text { from his lodgings. }\end{array}$ & $\begin{array}{l}5 \\
\text { years }\end{array}$ & I9 \\
\hline
\end{tabular}

1 This case was classed as "satisfactory" in the Disposal Book. 
Types of Unsatisfactory Cases-(Continued).

\begin{tabular}{|c|c|c|c|c|c|c|}
\hline Name. & 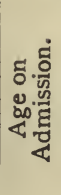 & 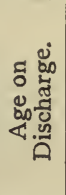 & $\begin{array}{l}\text { Previous } \\
\text { History. }\end{array}$ & Record. & 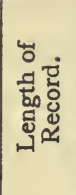 & 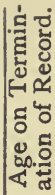 \\
\hline John S. & I3 & $\begin{array}{c}1903 \\
16\end{array}$ & $\begin{array}{l}\text { Charged with } \\
\text { beyond parent's } \\
\text { control. Father } \\
\text { dead; mother } \\
\text { living with an- } \\
\text { other man. }\end{array}$ & $\begin{array}{l}\text { Igo3. John employed as pit } \\
\text { boy. } \\
\text { Igo6. Out of work. Re- } \\
\text { convicted. }\end{array}$ & $\begin{array}{c}4 \\
\text { years }\end{array}$ & 20 \\
\hline
\end{tabular}

\section{Remarks.}

No. 5 was admitted at the age of I2. I should have classed this case as unsatisfactory, but as it was entered as satisfactory in the Disposal Book, there may possibly have been some favourable report not noted down in the record. Otherwise, this boy seens in a fair way to joining the ranks of the unemployable.

Nos. 6,7 , and 8 are poor records.

In fact, all the records obtained from this school compare most unfavourably with those of the Industrial School (No. 2), which is the next on my list.

\section{The IndUStRIAL School For BOys (No. 2)}

This school is certified for 60 boys, and was first started in 1874. At the time of my visit a new wing was being erected, and the school when completed will accommodate roo boys.

With regard to industrial training, I quote from some notes sent to me by the schoolmaster:

"Gardening.-This is the branch of the work that by far the larger part of the boys love most. We have 3 fine greenhouses, and about 5 acres of tilled land. The master gardener 
has 12 boys each half day under his care. They are taught flower-gardening, market-gardening, and French-gardening, digging and trenching, sowing seeds, manuring, utilisation of space, manipulation of cloches and French frames, pruning, layering, bedding-out, \&c.--all forming topics for very detailed lectures. And the business side is not neglected, as the boys themselves sell the produce and keep small books to make themselves conversant with current trade prices.

"Poultry-farming.-Some of the boys look after the poultry farm. Regular feeding, punctual collection and labelling of eggs, perfect cleanliness, rearing of chickens, and careful penning of the different species are important points which the boys must attend to.

"Tailoring.-The tailor's shop is an important branch. All the boys' clothes are made on the premises, with the exception of shirts, jerseys, and boots. The uniform is very smart, and does the tailor masters and the tailor boys great credit. . . To watch some of the smaller boys seaming, felling, making button-holes, sewing on buttons, \&c., as if their whole life depended upon its perfection, is a sight of a lifetime.

"Laundry Work.-The laundry is another part of our school. The laundress usually has 4 boys helping her with the work, which is considerable. In this establishment, as in all other branches of training, the boys are taught to manage the entire work, and occasionally they do so.

"Cooking.-Many of the boys are trained to be cooks in the kitchen.

"Carpentering.-Some are carpenters, learning their trade in an outside centre, although when the new wing is completed a special carpenter's shop will be opened.

"Shoemaking.-Some are shoemakers; and although we make no new boots, yet there are some repairs which test the boys' abilities to the full.

"Baking.-The bakehouse claims the attention on Fridays 
of 4 boys. These bake 34 stones of flour, sufficient for a week.

"The physical drill of these scholars is famous in the neighbourhood. The Government inspector reports: 'The physical training is absolutely first-rate, as it has been for years past.' 1

"Of 39 boys who are 13 years of age or over, 29 are regularly engaged in skilled occupations.

"Of I7 boys who have left the school during the past year I4 entered skilled or progressive occupations, and I 2 of these situations were found by the school." 2

The earliest of my records dates from the year IgOI; the superintendent of this school having held his present position for II years. He was previously schoolmaster in the Boys' Industrial School (No. I).

Of the 80 records procured from this school-

73 were satisfactory.

7 were doubtful or fairly satisfactory, and none were definitely unsatisfactory.

The average length of record of 54 of the records of which I have all the dates is 6.6 years. The average age to which these 54 records are kept is 22.2 years.

There are two features in particular which stand out from the general impressions which I received of this school :-

I. The cheerfulness and content of its inmates.

2. The loyalty and affection for their school and its headmaster continually evinced in the many letters from old boys which I read.

I visited this school three or four times, and on each occasion the door was answered by a very smiling, happylooking boy, who held himself well, and smartly saluted. Sometimes I would hear him in the distance whistling to himself as he came along the corridor. I do not think it was always the same boy who answered my ring.

1 Report of the Inspector of Reformatory and Industrial Schools, 19ro, p. 144 .

2 See Appendix B. 
I stayed for several weeks in the neighbourhood of this school, and one often met these boys in the town and bought flowers from them (the produce of their own garden) at the door.

They are very popular in the neighbourhood, and people one knew would sometimes say: "Oh! whenever we want a boy we get one from the Industrial School, they are so smart and thorough about their work."

When I went to the Industrial School No. I the door was locked, and on the other side sat a small boy knitting. Before I left, this boy hastened to tell the superintendent, who either came and let me out himself or gave the boy the key. I went only twice, and I do not know whether I saw a different boy on each occasion or not. The impression I got was of a very subdued, almost cowed, little boy. This may, of course, have been the boy's natural attitude, and not the result of discipline at all.

I have mentioned that I have not gone into the question of the administration of these schools at all, so that I do not know in the least in what way No. I differed from No. 2 in this respect. I simply give the general impressions received.

No. I was a very splendid modern building, with a fine entrance hall. The entrance to No. 2 was distinctly insignificant, and the door opened on to a narrow stone passage; the whole place, moreover, was more or less at sixes and sevens, owing to the building operations then in progress.

It may be thought by a strict disciplinarian that the boy who opened the door of school No. 2 ought not to have whistled. One knows that such behaviour is prohibited for instance during lesson hours. What I personally felt was that to the boy who whistled the institution was a home; to the boy who looked subdued it had never been anything but an institution.

I had an opportunity of reading a great many letters from old boys. One boy wrote at the time of the present coal 
strike, from a town some distance away, and declared that he would come on foot to the school reunion if unable to get there in any other way. Another from Canada complained that he had not heard from the superintendent for some time, and reminded him for how much his letters counted to a person all alone in the world.

Another, who was in the army, describes how he has bragged about his school to the rest of his comrades (many of them Industrial School boys); how none of them had enjoyed such good times as he had done, and how much they wished that they had been brought up in such a splendid school.

It seems difficult to realise that the feeling displayed by many of these boys for their old school-a school whose name is, I suppose, associated in the minds of respectable workingclass people with sorrow and disgrace-was in its way as ardent and as keen as that of the upper or middle-class boy for any one of the famous public schools of England.

One feels that if much depends upon the personality of the head of a public school, this must much more be the case with this little provincial reformatory, whose scholars are already marked out as victims of a bad environment or a bad heredity, and who now know no other home.

The terms "on licence" or "licensed" which will be found in these records refer to boys let out before the age of 16 , when their term expires. During this period they may be recalled at any time by the superintendent should their conduct be unsatisfactory. There is a working boys' home in connection with the school, in which many of these boys live. 
Types of Satisfactory Cases.

\begin{tabular}{|c|c|c|c|c|c|c|}
\hline Name. & 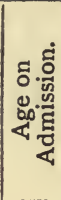 & 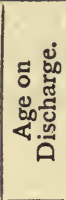 & $\begin{array}{l}\text { Previous } \\
\text { History. }\end{array}$ & Record. & 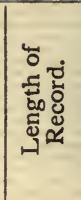 & 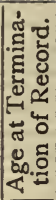 \\
\hline $\begin{array}{l}\text { r. } \\
\text { Henry } \\
\text { D. }\end{array}$ & 12 & $\begin{array}{c}1905 \\
16\end{array}$ & $\begin{array}{l}\text { "Neglected." } \\
\text { Mother bad; } \\
\text { had been di- } \\
\text { vorced. }\end{array}$ & 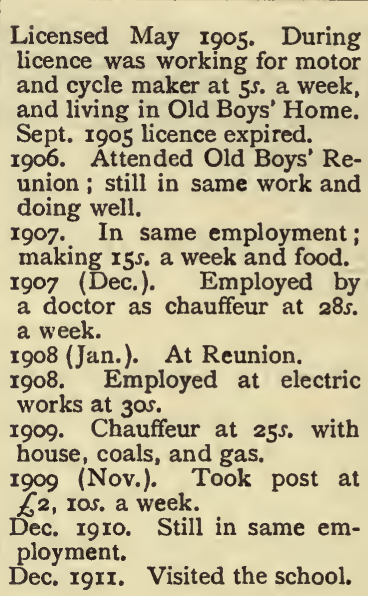 & $\begin{array}{c}6 \\
\text { years }\end{array}$ & 22 \\
\hline $\begin{array}{l}2 . \\
\text { Joseph } \\
\text { S. }\end{array}$ & II & $\begin{array}{c}1906 \\
15\end{array}$ & $\begin{array}{l}\text { Found wander- } \\
\text { ing : previous } \\
\text { ch a c t e r } \\
\text { "fair." Father } \\
\text { spends part of } \\
\text { his time in the } \\
\text { w ork h ouse; } \\
\text { w as on ce a } \\
\text { but cher, but } \\
\text { had been " sold } \\
\text { up." }\end{array}$ & $\begin{array}{l}\text { On licence Jan. rgo6. Ap- } \\
\text { pointed assistant gardener to } \\
\text { the school; lives in Old Boys' } \\
\text { Home; earns 5s. a week, } \\
\text { board and lodging, with wash- } \\
\text { ing and clothes provided. } \\
\text { Oct. rgo6. Licence expired. } \\
\text { rgo7 (Nov.). Doing well, and } \\
\text { turning out a first-class gar- } \\
\text { dener. } \\
\text { Dec. r9o7. Working for school, } \\
\text { living in Home, and banking } \\
\text { money. } \\
\text { Jan. rgo8. Continues satis- } \\
\text { factory. } \\
\text { rgo8. Took a post as under- } \\
\text { gardener at gs. with food. } \\
\text { Dec. rgog. Still as above with } \\
\text { r2s. } \\
\text { Jan. rgrr. Left for London. } \\
\text { April rgrr. Wrote asking to } \\
\text { come back, but advised to stay } \\
\text { in London, where he is working } \\
\text { in a nursery garden and doing } \\
\text { well. } \\
\text { Sept. rgrr. Wrote a pleasing } \\
\text { letter; doing well. }\end{array}$ & $\begin{array}{c}5 \\
\text { years }\end{array}$ & 20 \\
\hline
\end{tabular}


Types of Satisfactory Cases-(Continued).

\begin{tabular}{|c|c|c|c|c|c|c|}
\hline Name. & 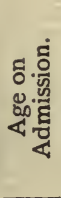 & 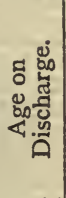 & $\begin{array}{l}\text { Previous } \\
\text { History. }\end{array}$ & Record. & 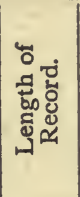 & 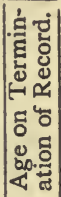 \\
\hline \multirow[t]{2}{*}{$\begin{array}{l}\text { 3. } \\
\text { Frank } \\
\text { H. ... }\end{array}$} & \multirow[t]{2}{*}{ II } & \multirow[t]{2}{*}{$\begin{array}{c}1907 \\
16\end{array}$} & $\begin{array}{l}\text { Charged with } \\
\text { non-attendance, } \\
\text { previous char- } \\
\text { a c t er good. } \\
\text { Father dead. } \\
\text { Mother lives in } \\
\text { a s l u m and } \\
\text { hawks herrings. } \\
\text { A bad home. }\end{array}$ & $\begin{array}{l}\text { April r908. Left for Canada. } \\
\text { July rgo8. Satisfactory letter; } \\
\text { is working for a farmer at } \\
6 \text { 'dollars a month. } \\
\text { Sept. rgo8. Letter ; is doing } \\
\text { well. } \\
\text { Aug. rgro. Letter from em- } \\
\text { ployer. Boy much improved } \\
\text { and doing well. } \\
\text { Nov. rgro. Letter. } \\
\text { rgrr, Dec. I, Canada. } \\
\text { "Dear Sir, -A few lines to let }\end{array}$ & $\begin{array}{c}5 \\
\text { years } \\
\\
\end{array}$ & 21 \\
\hline & & & \multicolumn{4}{|c|}{$\begin{array}{l}\text { you know that I am going on well, and hoping to see my } \\
\text { brother this next summer. I have done well since I came } \\
\text { out, and kept in work and had a good holiday each year. I } \\
\text { am getting } 35 \text { dollars a month and board." } \\
\text { rgrr. Sept. "If you can send my brother next spring I can } \\
\text { get him a good place at ro dollars. There are all kinds of } \\
\text { work for men who will work. I am saving a little every year } \\
\text { so that I can come and see you all at the school." } \\
\text { Jan. I9r2. "Dear Sir, - I am getting on good, and am think- } \\
\text { ing of going West to look for a homestead. . . I would } \\
\text { like to see more of our boys out here. I am driving mail } \\
\text { to a distance of } 20 \text { miles, and getting I5 dollars a month for } \\
\text { the winter, and board. I would like to know if my brother is } \\
\text { coming, as I could get a job for him or any other boy." } \\
\text { This boy has now taken up a homestead of his own. }\end{array}$} \\
\hline \multirow[t]{2}{*}{$\begin{array}{l}4 . \\
\text { Henry } \\
\text { A. }\end{array}$} & \multirow[t]{2}{*}{ ro } & \multirow[t]{2}{*}{$\begin{array}{c}1907 \\
16\end{array}$} & $\begin{array}{l}\text { Boy charged } \\
\text { with frequenting } \\
\text { the company of } \\
\text { thieves; a bad } \\
\text { home; mother } \\
\text { disreputable. }\end{array}$ & $\begin{array}{l}\text { May I907. Licensed to work } \\
\text { for Mrs. A. as gardener at } 75 . \\
\text { a week with food; living in } \\
\text { Old Boys' Home; is a good } \\
\text { lad. } \\
\text { June r907. Licence expired. } \\
\text { I908. Going on well; still } \\
\text { living in the Home. } \\
\text { May. Sailed for Canada. }\end{array}$ & $\begin{array}{c}5 \\
\text { years }\end{array}$ & $2 \mathbf{I}$ \\
\hline & & & \multicolumn{4}{|c|}{$\begin{array}{l}\text { July. Received postcards and letters. Likes his place and } \\
\text { the country well. } \\
\text { Dec. rgo8. Sent photo of farm and self; writes regularly; } \\
\text { very satisfactory report. } \\
\text { July rgog. Sent a dollar towards boys' camp. } \\
\text { Mar. rgro. Report from employer; boy earns } 85 \text { dollars a } \\
\text { year and board. } \\
\text { Sept. rgro. A fresh employer-at roo dollars. } \\
\text { Mar, rgrr. Letter; is doing well. } \\
\text { April rgrr. Letter; quite happy, and saving money. } \\
\text { Sept. rgrr. Letter with subscription for } 8 s .4 d \text {. towards } \\
\text { boys' camp. }\end{array}$} \\
\hline
\end{tabular}


Types of Satisfactory Cases-(Continued).

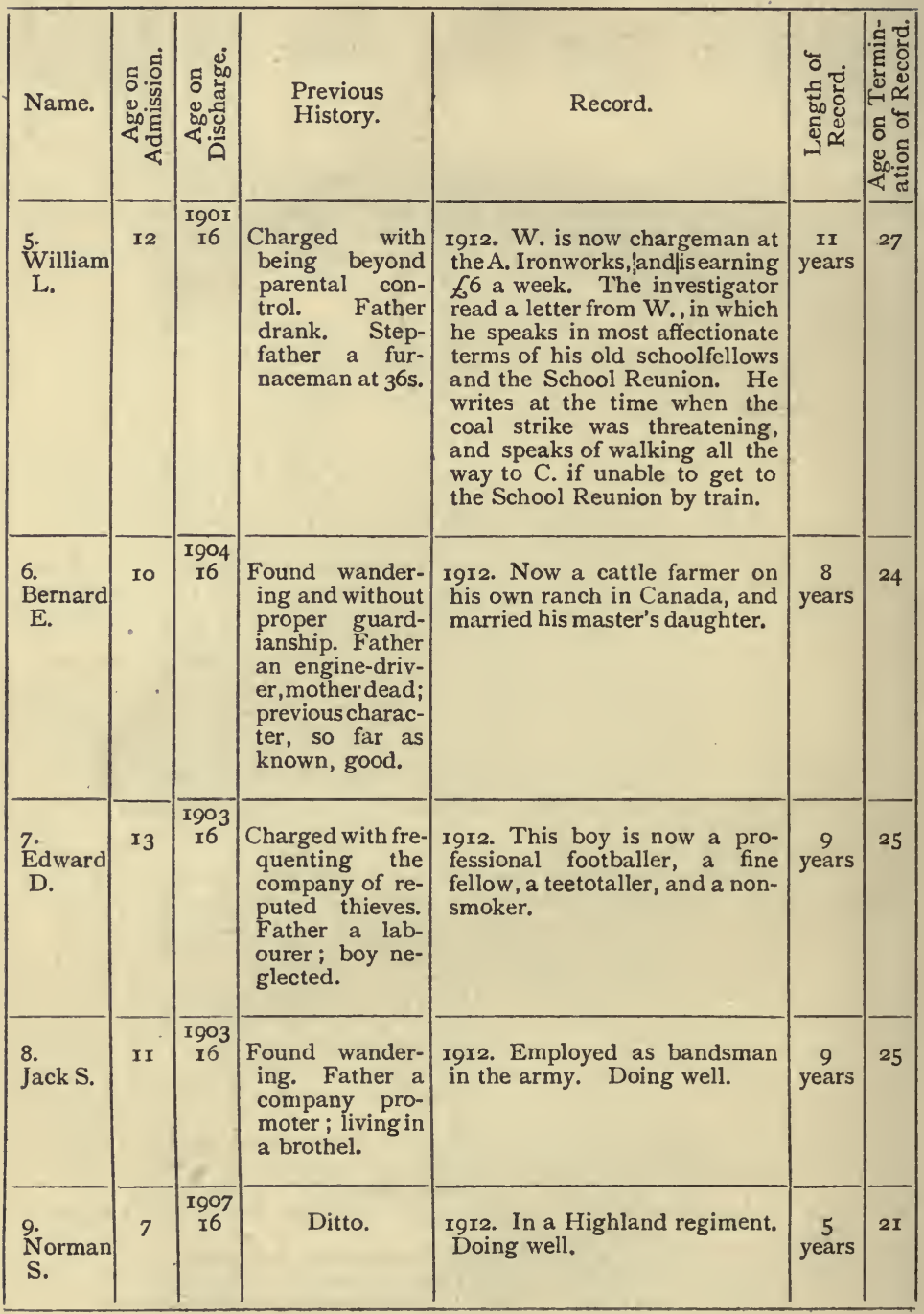


Types of Doubtful or only Fairly Satisfactory Cases.

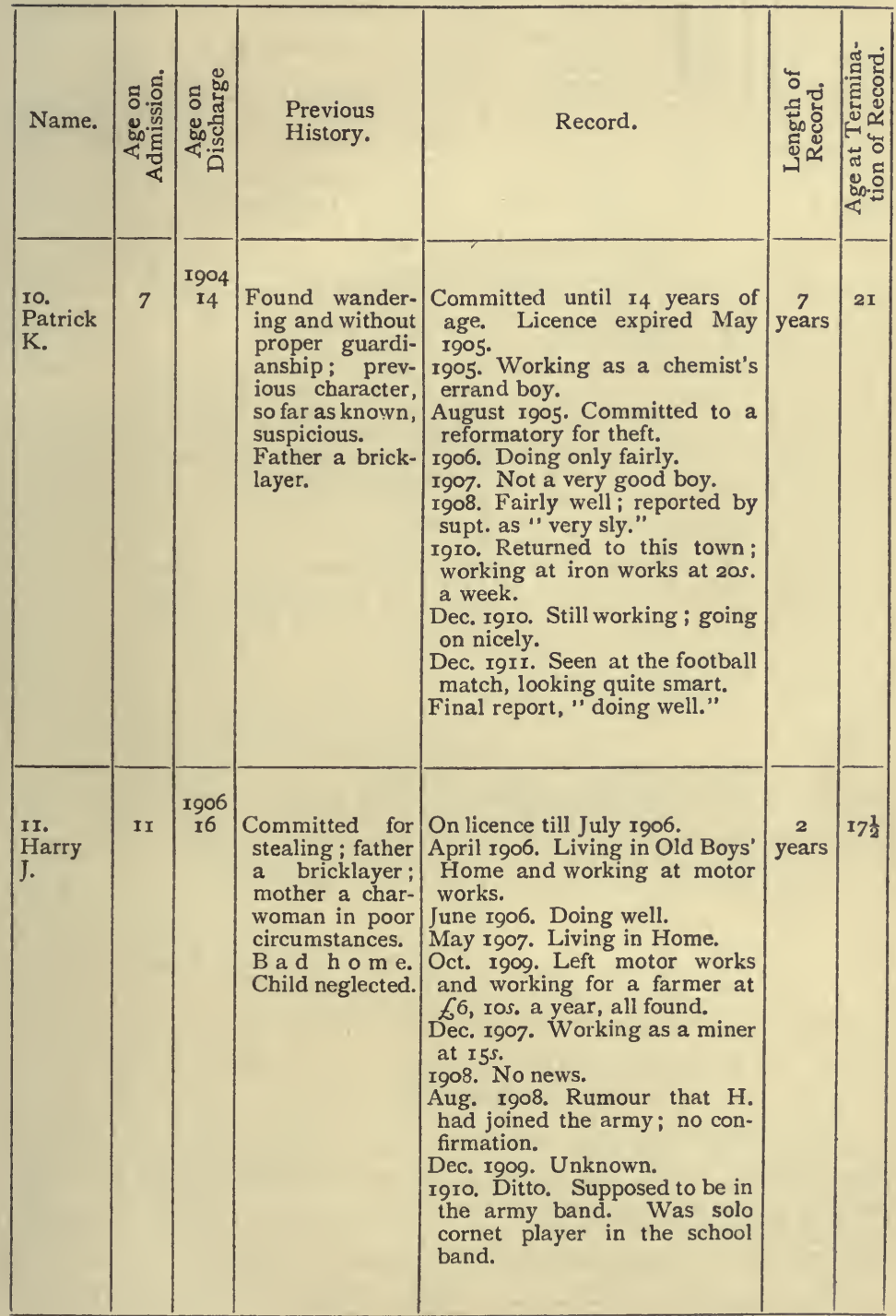


Types of Doubtful or only Fairly Satisfactory Cases-(Continued).

\begin{tabular}{|c|c|c|c|c|c|c|}
\hline Name. & 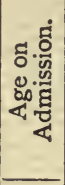 & 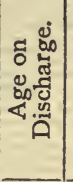 & $\begin{array}{l}\text { Previous } \\
\text { History. }\end{array}$ & Record. & 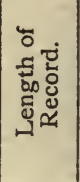 & 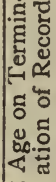 \\
\hline Iohn F. & 12 & $\begin{array}{c}1906 \\
16\end{array}$ & $\begin{array}{l}\text { Charged with } \\
\text { being in com- } \\
\text { pany of re- } \\
\text { puted thieves. } \\
\text { Previous cha- } \\
\text { racter a irly } \\
\text { good. Father } \\
\text { an engineer. }\end{array}$ & $\begin{array}{l}\text { 1906. Living with parents and } \\
\text { working as a painter. } \\
\text { Oct. r9o7. Working at blast } \\
\text { furnaces, r4s. a week. } \\
\text { Dec. I907. Out of work. This } \\
\text { boy has done somevery strange } \\
\text { things. His friends think he } \\
\text { is of unsound mind. } \\
\text { Nov. Igo8. Brought back after } \\
\text { being in two Boys' Homes else- } \\
\text { where. Given work in school } \\
\text { garden, finding food, clothing, } \\
\text { and pocket-money until work } \\
\text { could be got on a farm. Be- } \\
\text { haviour very strange. } \\
\text { Igog. Sent to an asylum for } \\
\text { supervision. } \\
\text { I9II. Discharged, and found } \\
\text { work at the shipyards. Seen } \\
\text { by a schoolfellow looking well- } \\
\text { dressed. }\end{array}$ & $\begin{array}{c}5 \\
\text { years }\end{array}$ & $2 I$ \\
\hline $\begin{array}{l}\text { I3. } \\
\text { Arthur I. }\end{array}$ & 9 & $\begin{array}{c}1906 \\
15\end{array}$ & $\begin{array}{l}\text { Frequenting the } \\
\text { company of } \\
\text { reputed thieves. } \\
\text { Mother dead. } \\
\text { Father a labour- } \\
\text { er. Home bad. }\end{array}$ & $\begin{array}{l}\text { Committed till I5 years of age } \\
\text { (time expired July I906). } \\
\text { June I906. Has post as assistant } \\
\text { gardener. } \\
\text { Aug. I906. Sent to Reforma- } \\
\text { tory. } \\
\text { I907. Good report. } \\
\text { I908 and r909. Satisfactory. } \\
\text { I910. Absconded from Reform- } \\
\text { atory. } \\
\text { Nov. I9rI. Joined an Irish } \\
\text { regiment. Reported as doing } \\
\text { well by superintendent. }\end{array}$ & $\begin{array}{c}5 \\
\text { years }\end{array}$ & 20 \\
\hline
\end{tabular}

\section{Remarks.}

With regard to the ages at which these children entered the school:-Nos. I, 5, and 12 were admitted at the age of 12 , and No. 7 at 13 . Of these No. 12 is a doubtful case, and the rest are satisfactory.

The record of No. I2 fulfils three conditions which, 
as has been previously stated, might be expected to react unfavourably upon his future career.

I. He was admitted at an age when it is difficult to counteract the effects of a previous environment.

2. It was found necessary to commit him to an asylum, and, therefore, he has been classed as a mental case.

3. On leaving the school he returned to his parents, though the record states that his home was a bad one. ${ }^{1}$

Records 8 and 9 suggest interesting conclusions. The children of a degenerate parent, probably by birth a member of Class $\mathrm{G}$, or possibly Class $\mathrm{H}^{2}{ }^{2}$ they have been rescued from the vicious environment into which their father's degeneracy has plunged them, and have become at 22 and 2 I respectively, so far as one can tell, decent, respectable members of society. These children, if left to themselves, and having no other alternative, would probably have followed in their father's footsteps, and appear to have inherited his vices. And it seems to me that it is often by illustrations such as these that certain Eugenists endeavour to support their theory of the futility of trying to redeem the members of a racially degenerate stock.

With regard to No. II :-This boy at the age of $17 \frac{1}{4}$ had already been engaged in four absolutely dissimilar occupations, and though I have given him the benefit of the doubt it seems most probable that this should be classified as an unsatisfactory case.

\section{THE X HOME FOR BOYS}

This Home was started about eleven years ago in one of the suburbs of a great city. The accommodation is for 34

1 I am inclined to think that there must have been some special reason for allowing this boy to return to his friends, because in this school, as in all others of the same nature, the greatest care is taken to prevent these children from returning to a former environment ; for this reason many of them are sent straight to Canada, and this is, of course, the raison d'être of the Y. Emigration Homes.

2 See page $\mathrm{I}$, above. 
boys, but at present, owing to the lack of funds, there are only about 20 .

The Home originally consisted of 2 private houses, which have since been thrown into one. A playroom is provided for the younger boys, and a combined study and meal-room for the elder. The latter have also separate bedrooms, which, although plainly furnished, give scope for just those little individual touches which so seldom show themselves in a typical institution room.

The life here is essentially home-like; and though it may perhaps possess points in common with the Poor Law Scattered Home, yet it differs considerably, as in this case the foster mother or superintendent is a woman of culture, having a very varied experience of social work. The lady superintendent is assisted by a matron who is a trained nurse, and an assistant matron. Those of the children who are old enough attend the nearest council and church school.

It is particularly desired that a child should be admitted at as early an age as possible, and at the time of my visit the youngest boy was two years old.

On admission to the home, the parents of the child, if alive, agree to renounce all claim to determine its future.

Of records I have Io. They are not entered in any casebook, but were given to me verbally by the lady superintendent. As far as she could remember, these were all the children who had passed out of her hands since the Home was started.

I have already mentioned in section II (page 12 , above) that I do not consider these records of any value as records in themselves. Two only have been kept for five and six years, and of 4 the length of record is not given, but I imagine they were kept only for very short periods. But the histories of some of these children are especially interesting, as showing what may be made of the slum-child in a better environment. Most of the children were sent to the Home from London slums. 
Satisfactory Cases.

\begin{tabular}{|c|c|c|c|c|c|c|c|}
\hline Name. & 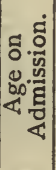 & 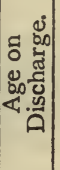 & History. & $\begin{array}{c}\text { Character in } \\
\text { Home. }\end{array}$ & Record. & 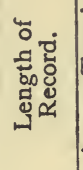 & 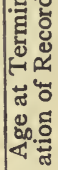 \\
\hline W. B. & 8 & 18 & $\begin{array}{l}\text { The father of this } \\
\text { boy was con- } \\
\text { sumptive and a } \\
\text { chronic invalid. } \\
\text { The mother also } \\
\text { w a a i li ng. } \\
\text { They lived in a } \\
\text { London slum, } \\
\text { and the children } \\
\text { were on the } \\
\text { streets. }\end{array}$ & $\begin{array}{l}\text { This boy showed } \\
\text { self-will and } \\
\text { temper amount- } \\
\text { ing almost to } \\
\text { insanity, but } \\
\text { was honest and } \\
\text { wished to do } \\
\text { right. Seen by } \\
\text { a mental speci- } \\
\text { alist who pre- } \\
\text { dicted lunacy or } \\
\text { epilepsy if tem- } \\
\text { per not con- } \\
\text { trolled. The } \\
\text { boy gradually } \\
\text { acquired self- } \\
\text { control and dur- } \\
\text { ing the last year } \\
\text { in the Home was } \\
\text { absolutely free } \\
\text { from temper. } \\
\text { Wasartistic and } \\
\text { loved drawing. }\end{array}$ & $\begin{array}{l}\text { This boy con- } \\
\text { tinued to live in } \\
\text { the Home and } \\
\text { studied at an art } \\
\text { school ; after- } \\
\text { wards was ap } \\
\text { prenticed to a } \\
\text { large firm of } \\
\text { jewellers; was } \\
\text { sent to Germany } \\
\text { for further ex- } \\
\text { perience, and is } \\
\text { now a designer } \\
\text { a nd p t tern } \\
\text { maker. }\end{array}$ & $\begin{array}{c}4 \\
\text { years }\end{array}$ & 19 \\
\hline $\begin{array}{l}\text { 2. } \\
\text { H. P. }\end{array}$ & II & 15 & $\begin{array}{l}\text { A dirty, thriftless } \\
\text { home ; parents } \\
\text { too poor to keep } \\
\text { the children. }\end{array}$ & & $\begin{array}{l}\text { This boy became } \\
\text { a soldier and } \\
\text { was solo-clar- } \\
\text { inet player in } \\
\text { the band, a } \\
\text { good musician } \\
\text { and had special } \\
\text { tuition; has a } \\
\text { very good re- } \\
\text { cord. }\end{array}$ & $\begin{array}{c}6 \\
\text { years }\end{array}$ & $2 \mathrm{I}$ \\
\hline Ç. & 8 & I7 & $\begin{array}{l}\text { This boy was ille- } \\
\text { gitimate. The } \\
\text { mother drank } \\
\text { and lived with } \\
\text { a married man } \\
\text { whose wife was } \\
\text { in an asylum. } \\
\text { She was left un- } \\
\text { provided for. }\end{array}$ & $\begin{array}{l}\text { This boy grew } \\
\text { up steady, hon- } \\
\text { est, and trust- } \\
\text { worthy. "Was } \\
\text { of a ver a gc } \\
\text { ability. }\end{array}$ & $\begin{array}{l}\text { Charles is now } \\
\text { in an account- } \\
\text { ant's office, do- } \\
\text { ing well, and is } \\
\text { presently to be } \\
\text { articled free of } \\
\text { premium. }\end{array}$ & $\begin{array}{c}\text { Not } \\
\text { given. }\end{array}$ & ? \\
\hline
\end{tabular}




\section{Environment and Efficiency}

Satisfactory Cases-(Continued).

\begin{tabular}{|c|c|c|c|c|c|c|c|}
\hline Name. & 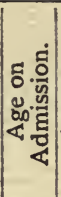 & 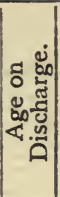 & History. & $\begin{array}{c}\text { Character in } \\
\text { Home. }\end{array}$ & Record. & 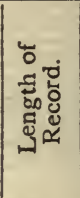 & 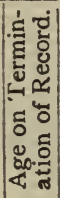 \\
\hline 4. $\mathrm{D}$. & 8 & 17 & $\begin{array}{l}\text { Mother delicate } \\
\text { and died when } \\
\text { C. was a baby. } \\
\text { C. lived with } \\
\text { his father and } \\
\text { brothers in a } \\
\text { London slum. } \\
\text { The father dis- } \\
\text { appeared one } \\
\text { day and was } \\
\text { never heard of } \\
\text { again. }\end{array}$ & $\begin{array}{l}\text { Learnt garden- } \\
\text { ing. }\end{array}$ & $\begin{array}{l}\text { C. D. is now in } \\
\text { Canada. He } \\
\text { went out at } 17 \text {, } \\
\text { and so far is } \\
\text { doing well. }\end{array}$ & ${ }^{2}$ & 18 \\
\hline S. A. S. & $?$ & $x 6$ & $\begin{array}{l}\text { Home very poor } \\
\text { but respectable; } \\
\text { nothing bad. }\end{array}$ & $=$ & $\begin{array}{l}\text { At I6 went into } \\
\text { the navy; has } \\
\text { an excellent } \\
\text { record. }\end{array}$ & $\stackrel{5}{\text { years }}$ & $2 X$ \\
\hline $\begin{array}{l}6 . \\
\text { Wil- } \\
\text { liam. }\end{array}$ & 8 & 14 & $\begin{array}{l}\text { Father a scamp } \\
\text { who deserted } \\
\text { his wife; the } \\
\text { latter reduced } \\
\text { to a b olute } \\
\text { poverty. The } \\
\text { mother a re- } \\
\text { spectable wo- } \\
\text { man of the } \\
\text { middle class. }\end{array}$ & & $\begin{array}{l}\text { rgr2. This boy is } \\
\text { now doing office } \\
\text { work, and is ex- } \\
\text { tremely satis- } \\
\text { factory. Living } \\
\text { with friends. }\end{array}$ & $\begin{array}{c}\text { Not } \\
\text { given. }\end{array}$ & ? \\
\hline
\end{tabular}

\section{Doubtful Cases.}

\begin{tabular}{|c|c|c|c|c|c|c|}
\hline$\stackrel{7}{\mathrm{~W}} . \mathrm{s}$. & Io & I5 & $\begin{array}{l}\text { This boy came } \\
\text { of a family of } \\
\text { tramps. He had } \\
\text { tramped all over } \\
\text { England, Scot- } \\
\text { land, and } \\
\text { Wales. Mother. } \\
\text { disreputable. } \\
\text { Disreputable re- } \\
\text { lat ives; no } \\
\text { morals. }\end{array}$ & 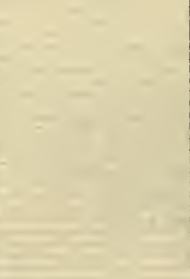 & $\begin{array}{l}\text { W. improved tre- } \\
\text { mendously ; is } \\
\text { a b s o l u t e } 1 \text { y } \\
\text { honest, but does } \\
\text { not settle for } \\
\text { long at a time } \\
\text { to any work. } \\
\text { If he can get } \\
\text { over roving ten- } \\
\text { dencies will do } \\
\text { well. }\end{array}$ & $\begin{array}{l}\text { Not } \\
\text { given. }\end{array}$ \\
\hline
\end{tabular}


Doubtful Cases-(Continued).

\begin{tabular}{|c|c|c|c|c|c|c|c|}
\hline Name. & 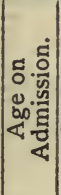 & 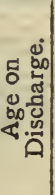 & History. & $\begin{array}{c}\text { Character in } \\
\text { Home. }\end{array}$ & Record. & 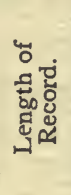 & 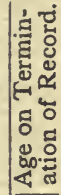 \\
\hline $\begin{array}{l}8 . \\
\text { Henry. }\end{array}$ & I3 & 15 & $\begin{array}{l}\text { This boy was a } \\
\text { s tre et a rab. } \\
\text { The home was } \\
\text { of a low type. } \\
\text { Father a dock } \\
\text { labourer. }\end{array}$ & $\begin{array}{l}\text { H. told lies and } \\
\text { stole because } \\
\text { he had no other } \\
\text { standard. When } \\
\text { taught he be- } \\
\text { came absolutely } \\
\text { hon es t a n d } \\
\text { truthful, but } \\
\text { could not live } \\
\text { down I3 years } \\
\text { of street life. } \\
\text { Could not be } \\
\text { respectable. He } \\
\text { prefe r e d a } \\
\text { piece of bread } \\
\text { and cheese in } \\
\text { his hand to a set } \\
\text { meal. But tre- } \\
\text { mendously im- } \\
\text { proved. }\end{array}$ & $\begin{array}{l}\text { 1912. This boy } \\
\text { now has work } \\
\text { in London, but } \\
\text { is lost sight of. }\end{array}$ & $\begin{array}{c}\text { I } \\
\text { year }\end{array}$ & I6 \\
\hline ค. $\mathrm{K}$. & II & I5 & $\begin{array}{l}\text { Born in a Lon- } \\
\text { don workhouse } \\
\text { lived there till } \\
\text { 1o years old; } \\
\text { one of a large } \\
\text { family of illegi- } \\
\text { timate children. }\end{array}$ & $\begin{array}{l}\text { B. was abso- } \\
\text { lutely idle, } \\
\text { in ane, and } \\
\text { vapid. }\end{array}$ & $\begin{array}{l}\text { Sent to Canada. } \\
\text { Because no em- } \\
\text { ployer could do } \\
\text { anything with } \\
\text { him, only out a } \\
\text { year. }\end{array}$ & $\stackrel{\text { I }}{\text { year }}$ & 16 \\
\hline
\end{tabular}

\section{Unsatisfactory.}

\begin{tabular}{|c|c|c|c|c|c|c|c|}
\hline $\begin{array}{l}\text { ro. } \\
\text { Frank. }\end{array}$ & I4 & I $5 \frac{1}{2}$ & $\begin{array}{l}\text { This boy was a } \\
\text { street arab; } \\
\text { parents dead, } \\
\text { lived in a bad } \\
\text { slum. }\end{array}$ & $\begin{array}{l}\text { F. absolutely im- } \\
\text { possible. Was } \\
\text { re ceive d too } \\
\text { late. }\end{array}$ & $\begin{array}{l}\text { Quite unemploy- } \\
\text { able; was sent to } \\
2 \text { other Homes } \\
\text { and dismissed } \\
\text { from both. }\end{array}$ & $?$ & $?$ \\
\hline
\end{tabular}




\section{Remarks.}

The record of No. I (W. B.) is a good illustration of the latent possibilities for good of the ordinary slum child, from which, by means of careful training and encouragement, such satisfactory results may be produced, and which, on the other hand, meeting with no appropriate stimulus in the external environment, must inevitably die away through disuse. This boy, born into Class A, may now certainly be looked upon as a member of Class $\mathrm{F}$.

No. 3, also born into Class A, will, if he takes the social position of other members of his profession, in future be ranked in Class $\mathrm{H}$.

No. 8 was 13 on admission. It seems probable that had this boy been admitted at the age of 7 or 8 his record would have been satisfactory in every respect. No. Io also was admitted too late.

\section{Children Boarded out by The Glasgow PARISH COUNCIL}

With regard to the manner in which these children are boarded-out, I quote from a report on "The Boarding-out of Parish Children in Scotland," by Miss Aikman (Member of the Glasgow Parish Council). This report was printed in the year 1904, and refers especially to children on the Boarded-out Roll of the Glasgow Parish Council at that date; the twenty records which I possess spread over a period of years from I895 to I9I2 :

"The average cost of maintenance for a boarded-out child under the Glasgow Parish Council amounted to slightly over EI 8 per annum for the year 1903. This sum included aliment, clothes, school books, medical relief, and visitations by members of Council, and the Inspector of Poor and his assistants.

"The aliment paid at present is 3 s. weekly for children under 6 years old; $3 s .6 d$. for children between the ages of 6 and Io, and $4 s$. for children above Io years. 
"Nothing is spared to equip the child thoroughly for a successful future. If a child shows special aptitude in any particular line, care is taken to provide whatever is necessary to follow it out. It may be of interest to note that, where at all possible, brothers and sisters are placed together, so that the family tie may not be altogether broken.

"Children from a few months up to 13 years of age are boarded-out. Before being boarded-out a child is supplied with a new outfit of clothing., A duplicate of the outfit of clothing is either taken with the children for their use, or it is forwarded the next day.

"The children are visited at least twice a year by the Inspector or his assistants, and once a year by two Members of the Council, accompanied by an official, and all are surprise visits. ... The majority of the guardians of these children are crofters and villagers who have comfortable homes, and are found to be of respectable character.

"After a child has left school a situation is found for it, either by its guardian or by the Inspector. In the majority of cases the child obtains employment in the district where it is boarded, and often continues to live with the guardian." ${ }^{1}$

$\begin{array}{cccc}\text { No. of Children on Boarded-out Roll, March } & \text { 1904. } \\ \text { Orphans. } & \text { Deserted. } & \text { Separated. } & \text { Total. } \\ 435 & 280 & \mathbf{1 1 9 2} & \mathbf{9 0 7}\end{array}$

\section{Classification of Separated Cases.}

Both parents drunken, been in prison, \&c. . . . . . . $\quad$ Ig8

Parents sent to gaol (Cruelty to Children Act) : $: \quad$ : $\quad 6_{2}$

Father dead, mother drunken and immoral $: 0^{*}: 3^{17}$

Father in hospital seriously ill, mother dead : : : : ${ }^{2}$

Mother in hospital seriously ill, father dead : . . . . 19

Mother dead, father been drunken, in prison or deserted : . $\quad$ I 48

Illegitimate, mother been drunken, immoral, or in prison . . $\quad 222$

Father dead, mother unfit to support, not suitable, unable to control . $\quad 147$

From variety, such as remits from Sheriff Court, one parent dead, other in asylum, illegitimate through bigamous marriage, \&c. $.3^{5}$

Father in hospital, mother drunken $\cdot \cdot \cdot \cdot \cdot \frac{2 \mathrm{II}}{\mathrm{I}_{202}}$

Deduct separated cases taken off Roll during month . . .

$\frac{10}{1192}$

1 This remark does not seem to apply to the records which I shall quote later. 
As to the children boarded-out in Iona by the Glasgow Parish Council, I have not needed to classify the twenty records sent to me by Dr. Mackenzie, as I have only received satisfactory ones. The average length for which 17 of them are kept is 9 years. The average age to which 17 of them are kept is 24.5 years.

Of these 20 records, 12 are of children admitted at 8 years and under, and only 2 at 12 years or over.

\begin{tabular}{|c|c|c|c|c|c|c|}
\hline Name & 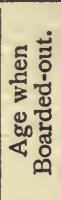 & 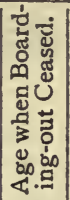 & $\begin{array}{l}\text { Previous } \\
\text { History. }\end{array}$ & Record, & 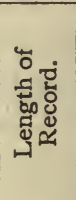 & 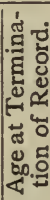 \\
\hline Alec D. & 8 & $\begin{array}{c}x 904 \\
18\end{array}$ & $\begin{array}{l}\text { The father of this lad was } \\
\text { a hawker of stucco, \&c. } \\
\text { He made a precarious } \\
\text { living for himself and } \\
\text { his family, and the } \\
\text { records of the parish } \\
\text { show that the neigh- } \\
\text { bours of the district } \\
\text { where they resided com- } \\
\text { plained that the children } \\
\text { were being starved and } \\
\text { neglected. }\end{array}$ & $\begin{array}{l}\text { rgr2. Alec is at pre- } \\
\text { sent managing the } \\
\text { croft for the two sisters } \\
\text { of his late guardian, } \\
\text { and has done so for } \\
\text { the past two years. } \\
\text { He is in every sense } \\
\text { a well-doing, success- } \\
\text { ful business young } \\
\text { man. }\end{array}$ & $\begin{array}{c}8 \\
\text { years }\end{array}$ & 26 \\
\hline John N. & 9 & $\begin{array}{c}1904 \\
15\end{array}$ & $\begin{array}{l}\text { The father of this boy } \\
\text { who was a clerk in a } \\
\text { good situation deserted } \\
\text { him in I898. The } \\
\text { mother died in hospital } \\
\text { in the same year. } \\
\text { Father dismissed from } \\
\text { his employment for } \\
\text { drunkenness and mis- } \\
\text { behaviour. }\end{array}$ & $\begin{array}{l}\text { rgr2. J. is now a } \\
\text { stoker in the navy, } \\
\text { which he joined in } \\
\text { rgog. He is getting } \\
\text { on well, having } 2 \frac{1}{2} \\
\text { years' service without } \\
\text { one "black mark" } \\
\text { against him. Prior } \\
\text { to joining the navy he } \\
\text { was in the merchant } \\
\text { shipping service. }\end{array}$ & $\begin{array}{c}8 \\
\text { years }\end{array}$ & 23 \\
\hline $\begin{array}{l}\text { 3. } \\
\text { Patrick } \\
\text { T. }\end{array}$ & 3 & $\begin{array}{c}1906 \\
18 \\
2\end{array}$ & $\begin{array}{l}\text { Illegitimate. The parents } \\
\text { of this lad are both } \\
\text { supposed to be dead. } \\
\text { They lived together for } \\
\text { a number of years, and } \\
\text { there were three illegi- } \\
\text { timate children born. } \\
\text { They tramped all over } \\
\text { the country i it is said } \\
\text { that both drank, especi- } \\
\text { ally the father. }\end{array}$ & $\begin{array}{l}\text { rgi2. This young man } \\
\text { is now a salesman } \\
\text { in a store, and is } \\
\text { doing well in every } \\
\text { respect; he has been } \\
\text { in this situation for } \\
\text { three years. }\end{array}$ & $\begin{array}{c}6 \\
\text { years }\end{array}$ & 24 \\
\hline
\end{tabular}




\begin{tabular}{|c|c|c|c|c|c|c|}
\hline Name. & 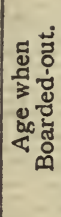 & 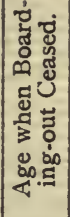 & $\begin{array}{l}\text { Previous } \\
\text { History. }\end{array}$ & Record. & 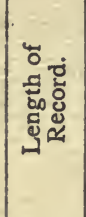 & 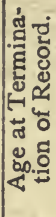 \\
\hline I. John L. & 8 & $\begin{array}{c}1903 \\
14\end{array}$ & $\begin{array}{l}\text { This boy's father, who } \\
\text { was an iron-roofer, died } \\
\text { in } 1895 \text {. The mother } \\
\text { was in receipt of out- } \\
\text { door aliment up till } \\
\text { r897, when the aliment } \\
\text { was discontinued on } \\
\text { account of her drinking } \\
\text { habits and neglecting } \\
\text { her house and family. } \\
\text { Since that date she has } \\
\text { been chargeable to the } \\
\text { parish in the poorhouse, } \\
\text { and left the poorhouse } \\
\text { last in October rgx. }\end{array}$ & $\begin{array}{l}\text { 1912. This youth is at } \\
\text { present in Chicago, } \\
\text { U.S.A., in one of the } \\
\text { large drapery stores } \\
\text { as a salesman, and } \\
\text { is getting on well. }\end{array}$ & $\begin{array}{c}9 \\
\text { years }\end{array}$ & 23 \\
\hline $\begin{array}{l}\text { P. } \\
\text { Peter } \\
\text { Q. }\end{array}$ & IO & $\begin{array}{c}\text { I9OI } \\
\text { I4 }\end{array}$ & $\begin{array}{l}\text { The father, a spinner, } \\
\text { died in r } 893 \text {. The } \\
\text { mother's out-door relief } \\
\text { was stopped in } 1907 \text { on } \\
\text { account of her immoral } \\
\text { habits and the fact that } \\
\text { she had given birth to } \\
\text { an illegitimate child, } \\
\text { and on the same date } \\
\text { she was sentenced to } 2 \mathrm{I} \\
\text { days imprisonment at } \\
\text { the City Police Court } \\
\text { for keeping a shebeen. }\end{array}$ & $\begin{array}{l}\text { Igr2. Peter is at pre- } \\
\text { sent employed in a } \\
\text { motor car manufac- } \\
\text { turing firm learning } \\
\text { motor car driving, } \\
\text { and is a specially } \\
\text { well - behaved lad, } \\
\text { sober, and industri- } \\
\text { ous. }\end{array}$ & $\begin{array}{c}\text { II } \\
\text { years }\end{array}$ & 25 \\
\hline $\begin{array}{l}6 . \\
\text { David } \\
\text { Q.1 }\end{array}$ & 8 & 14 & 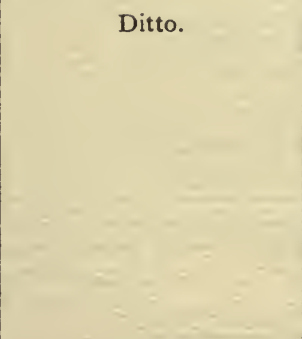 & $\begin{array}{l}\text { 1912. At present em- } \\
\text { ployed as a motor } \\
\text { car demonstrator in } \\
\text { a motor car manu- } \\
\text { facturing firm, and } \\
\text { is specially reserved } \\
\text { as chauffeur for the } \\
\text { directors; is spoken } \\
\text { very well of by his } \\
\text { employers; he keeps } \\
\text { himself very well } \\
\text { groomed and respect- } \\
\text { able. }\end{array}$ & $\begin{array}{c}\text { Not } \\
\text { given. }\end{array}$ & \\
\hline
\end{tabular}

1 Brother to No. 5 . 


\begin{tabular}{|c|c|c|c|c|c|c|}
\hline Name. & 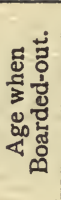 & 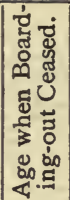 & $\begin{array}{l}\text { Previous } \\
\text { History. }\end{array}$ & Record. & 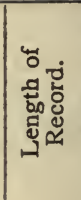 & 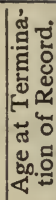 \\
\hline $\begin{array}{l}\text { 7. } \\
\text { Donald } \\
\text { O. }\end{array}$ & II & $\begin{array}{c}1906 \\
18\end{array}$ & $\begin{array}{l}\text { Father a carter, addicted } \\
\text { to drink, frequently in } \\
\text { prison for assault, was } \\
\text { in the habit of deserting } \\
\text { his children; he died in } \\
\text { Igo2. The mother also } \\
\text { addicted to drink, and } \\
\text { the parish took charge } \\
\text { of the children whilst } \\
\text { she was undergoing a } \\
\text { term of imprisonment } \\
\text { for drunkenness. She } \\
\text { died in I904. }\end{array}$ & $\begin{array}{l}\text { Igi2. D. is at present } \\
\text { a railway clerk and } \\
\text { has all along done } \\
\text { exceedingly well in } \\
\text { his work and be- } \\
\text { haviour, and is a par- } \\
\text { ticularly smart young } \\
\text { man. }\end{array}$ & $\begin{array}{c}6 \\
\text { years }\end{array}$ & 24 \\
\hline $\begin{array}{l}8 . \\
\text { James } \\
\text { K. }\end{array}$ & II & 14 & $\begin{array}{l}\text { The mother died in hos- } \\
\text { pital from the effects } \\
\text { of burning whilst under } \\
\text { the influence of drink. } \\
\text { The father remarried, } \\
\text { and when this lad be- } \\
\text { came chargeable the } \\
\text { father was in prison for } \\
\text { assaulting his second } \\
\text { wife, who was living } \\
\text { apart from him. They } \\
\text { were both much ad- } \\
\text { dicted to drink, and } \\
\text { treated the lad very } \\
\text { badly. }\end{array}$ & $\begin{array}{l}\text { Igr2. J. is working as } \\
\text { a chief ship's steward } \\
\text { on a foreign trading } \\
\text { steamer, to which } \\
\text { posit i on he has } \\
\text { worked himself up, } \\
\text { and is doing well. } \\
\end{array}$ & $\begin{array}{c}\text { No } \\
\text { dates } \\
\text { given. }\end{array}$ & \\
\hline $\begin{array}{l}\text { Mary } \\
\text { E. }\end{array}$ & 8 & $\begin{array}{c}1901 \\
17\end{array}$ & $\begin{array}{l}\text { The father, a bookbinder, } \\
\text { died in I } 888 \text {. Mother } \\
\text { in receipt of aliment } \\
\text { from the Parish, but } \\
\text { was struck off the out- } \\
\text { door roll for drinking } \\
\text { in I891, and died sud- } \\
\text { denly the same year. }\end{array}$ & $\begin{array}{l}\text { I9I2. M. is now a } \\
\text { certificated headmis- } \\
\text { tress in a public } \\
\text { school, where she is } \\
\text { doing well. }\end{array}$ & $\begin{array}{c}\text { II } \\
\text { years }\end{array}$ & 28 \\
\hline $\begin{array}{l}\text { ro. } \\
\text { Rachel } \\
\text { W. }\end{array}$ & 7 & $\begin{array}{c}1893 \\
15\end{array}$ & $\begin{array}{l}\text { The father died in } 1883 \text {, } \\
\text { the mother in r } 885 . \\
\text { The mother prior to her } \\
\text { death was much ad- } \\
\text { dicted to drink. }\end{array}$ & $\begin{array}{l}\text { I912. At present a cer- } \\
\text { tificated fever nurse, } \\
\text { and is in one of the } \\
\text { city hospitals under- } \\
\text { going general train- } \\
\text { ing, and has all along } \\
\text { done very well. }\end{array}$ & $\begin{array}{c}19 \\
\text { years }\end{array}$ & 34 \\
\hline
\end{tabular}




\begin{tabular}{|c|c|c|c|c|c|c|}
\hline Name. & 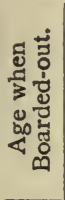 & 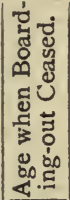 & $\begin{array}{l}\text { Previous } \\
\text { History. }\end{array}$ & Record. & 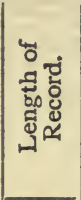 & 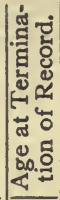 \\
\hline $\begin{array}{l}\text { Ir. } \\
\text { Ethel } \\
\text { P. }\end{array}$ & 8 & $\begin{array}{c}\mathbf{1 8 9 9} \\
\mathbf{r}\end{array}$ & $\begin{array}{l}\text { The parents of this girl } \\
\text { are both supposed to be } \\
\text { dead. The mother died } \\
\text { in the Infirmary, and } \\
\text { the father is supposed } \\
\text { to have died about r6 } \\
\text { years ago. The girl } \\
\text { became chargeable in } \\
\text { r889, being deserted by } \\
\text { her father, and she was } \\
\text { admitted to the poor- } \\
\text { house on the above } \\
\text { date. He was much } \\
\text { addicted to drink; was } \\
\text { sentenced to terms of } \\
\text { imprisonment on three } \\
\text { occasions for deserting } \\
\text { and neglecting his child. }\end{array}$ & $\begin{array}{l}\text { 1912. E. is at present } \\
\text { a certificated nurse, } \\
\text { and has all along } \\
\text { done well in every } \\
\text { way. }\end{array}$ & $\begin{array}{c}\mathbf{I}_{3} \\
\text { years }\end{array}$ & 28 \\
\hline $\begin{array}{l}\text { I2. } \\
\text { Jane F. }\end{array}$ & 5 & $\begin{array}{l}\text { rgor } \\
15\end{array}$ & $\begin{array}{l}\text { This girl's mother, who } \\
\text { was a pottery worker, } \\
\text { died in the poorhouse } \\
\text { in } 1892 \text {. She had two } \\
\text { illegitimate children } \\
\text { born to different fathers. } \\
\text { She belonged to a } \\
\text { family with a bad his- } \\
\text { tory, who were well } \\
\text { known to the officials of } \\
\text { the parish as criminals. }\end{array}$ & $\begin{array}{l}\text { IgI2. J. F. is at pre- } \\
\text { sent a domestic ser- } \\
\text { vant with a lady in } \\
\mathrm{R}_{\text {., where she has }} \\
\text { been for some years, } \\
\text { giving entire satis- } \\
\text { faction. }\end{array}$ & $\begin{array}{c}\mathbf{X I} \\
\text { years }\end{array}$ & 26 \\
\hline $\begin{array}{l}\text { B. } \\
\text { Bridget } \\
\text { Q.1 }\end{array}$ & 6 & $\begin{array}{c}1905 \\
14 \\
-\end{array}$ & $\begin{array}{l}\text { The father, who was a } \\
\text { spinner, died in I893. } \\
\text { The mother was in re- } \\
\text { ceipt of out-door ali- } \\
\text { ment, which wasstopped } \\
\text { in } 1907 \text { on account of } \\
\text { her immoral habits, and } \\
\text { having given birth to } \\
\text { an illegitimate child. } \\
\text { On the same date she } \\
\text { was sentenced to } 21 \\
\text { days' imprisonment at } \\
\text { the City Police Court for } \\
\text { keeping a shebeen. }\end{array}$ & $\begin{array}{l}\text { Igr2. B. is now en- } \\
\text { gaged as lady's maid } \\
\text { in a good family, } \\
\text { and has been in this } \\
\text { situation for fully two } \\
\text { years past, where she } \\
\text { is giving entire satis- } \\
\text { faction. }\end{array}$ & $\begin{array}{c}7 \\
\text { years }\end{array}$ & 21 \\
\hline
\end{tabular}

1 Sister to 5 and 6. 


\begin{tabular}{|c|c|c|c|c|c|c|}
\hline Name. & 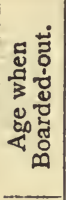 & 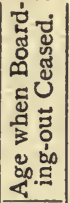 & $\begin{array}{l}\text { Previous } \\
\text { History. }\end{array}$ & Record. & 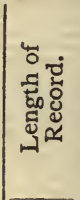 & 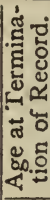 \\
\hline $\begin{array}{l}\text { I4. } \\
\text { Kate B. }\end{array}$ & 6 & $\begin{array}{c}1905 \\
16\end{array}$ & $\begin{array}{l}\text { The parents of this girl } \\
\text { have been chargeable to } \\
\text { this parish twenty-eight } \\
\text { times since August } 1886 \text {. } \\
\text { The mother died in } \\
\text { r } 890 \text {, and the father, a } \\
\text { coal miner, has applied } \\
\text { to this parish from } \\
\text { model lodging - houses } \\
\text { in the city, and has also } \\
\text { become chargeable to } \\
\text { v a r i o s p p r i sh e s } \\
\text { throughout Scotland, } \\
\text { and is at present an } \\
\text { inmate of T. Poor- } \\
\text { house. Since November } \\
\text { rgrr has been before } \\
\text { the magistrates for } \\
\text { begging and in prison } \\
\text { for deserting his child. } \\
\text { He tramps about the } \\
\text { country, and begs his } \\
\text { living as he moves } \\
\text { about. }\end{array}$ & $\begin{array}{l}\text { I912. K. is at present } \\
\text { training as a teacher } \\
\text { in a Training College, } \\
\text { and has done well in } \\
\text { her class examina- } \\
\text { tions, and very well in } \\
\text { her general behaviour } \\
\text { and habits. }\end{array}$ & $\begin{array}{l}7 \\
\text { years }\end{array}$ & 23 \\
\hline $\begin{array}{l}\text { I5. } \\
\text { Maud } \\
\text { C. }\end{array}$ & 6 & 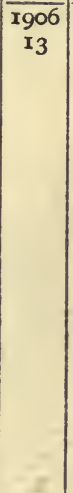 & $\begin{array}{l}\text { The parents of this girl } \\
\text { have been repeatedly } \\
\text { chargeable to Glasgow } \\
\text { Parish since r889, and } \\
\text { have an exceptionally } \\
\text { bad history. They are } \\
\text { drunken people, and } \\
\text { tramp from place to } \\
\text { place; have been fre- } \\
\text { quently in prison, and } \\
\text { are well known to the } \\
\text { officials of Glasgow } \\
\text { Parish as a "thoroughly } \\
\text { bad pair." Their re- } \\
\text { cords of applications } \\
\text { and chargeabilities in } \\
\text { the books of the parish } \\
\text { are very bad. }\end{array}$ & $\begin{array}{l}\text { 1908. She went as a } \\
\text { servant to Canada to } \\
\text { get away from her } \\
\text { parents, as she had } \\
\text { recollections of her } \\
\text { parents' conduct in } \\
\text { the district where she } \\
\text { was "boarded out." } \\
\text { The girl prior to her } \\
\text { marriage was a tele- } \\
\text { phone oferator in } \\
\text { Canada. } \\
\text { rgra. M. is at present } \\
\text { in Canada, and com- } \\
\text { fortably married. }\end{array}$ & $\begin{array}{c}6 \\
\text { years }\end{array}$ & 19 \\
\hline
\end{tabular}




\section{Remarks.}

These records seem to me on the whole to be more satisfactory than any others which I have collected, yet all these young men and women, highly estimable and blameless though their records would appear to be, are included in Mr. Mudge's wholesale denunciation of the children boarded-out in Iona, which appears in the Mendel Journal for I9I I.

He says: "Faced with the pressing problem as to what is to be done with this class of defective citizen, the Glasgow Parish Council cast their municipal eyes upon the beautiful and verdant Western Coast of Scotland and upon its honest and simple inhabitants. 'Here,' they said, 'is a good environment, and a trusty people; among the native population, Godfearing and honest, we may find a human environment which will appeal to the better nature of our morally and mentally crippled citizens. We cannot hope to do much with the parents, but with the children it is otherwise . . . and in the midst of these honest people we will plant our tares, the children of paupers, ne'er-do-wells, thieves, murderers, prostitutes, hooligans, drunkards, \&c. From such an ancestry we shall, with ratepayers' money and good environment, rear a community of civic saints.'

"But let us leave the intentions and come to the results; they are the very reverse of what it was intended they should be. Doubtless in a few cases there have been ostensible successes; I say ostensible, because in some of the supposed successful cases, with which I am acquainted, a sufficiently long period has not elapsed to enable me to judge of permanent success, and in a few cases it is possible that the ancestry has not been bad.

"Leaving then these questionable, untested, and unanalysed successes alone, what are the results with regard to the remainder?

"We may sum them up in a single sentence. It is, that in 
this beautiful island, with its historic and even sacred associations, a new slum area is being created by the operation of the inherent slum instincts of the putatively rescued denizens of Glasgow's slums.

"There we see in the making, not slum people by slum environments, but slums fashioned out of the depths of the slum instincts of a congenital race of slum producers."

In illustration, Mr. Mudge gives instances of "sheep worrying," of "the breaking up of evening classes," and of "Hooliganism." "The Glasgow rowdies congregate in bands, they link their arms, and, rushing through the village street in a serried rank, shouting, whistling and gesticulating, drive all others before them."

Dr. John Macpherson (Commissioner in Lunacy), who was requested, on account of Mr. Mudge's assertions, to inquire into the conditions of Glasgow Parish Council children in Iona, reports on the above assertions as follows:

"The island contains 222 inhabitants, and there are between 40 and 50 families. If the school children (60 in number), infants, and the older inhabitants and heads of families are deducted, there are left about 60 persons who might possibly behave in this manner. If again we deduct the younger female population, against whom the charge does not appear to be made, the number may be reduced to 30 , or less.

"But the indictment is distinctly made against 'Glasgow rowdies,' presumably males. There are on the island at present the following five Glasgow youths, hired as farm servants by the crofters" (the initials follow). "Last year there was another, who has since left.

"Of these six youths, three do not go to the village, or, if they do, only on errands. They are exceptionally quiet and well-behaved, and are exonerated by all my informants of any bad tendencies. There remain" (three other initials given). "The two former are more or less weak-minded, the latter has left the island and was not seen." 
Dr. M'Pherson goes on to explain how, in some way, these three youths came into collision with Mr. Mudge during the time he was resident in the island, and annoyed him in various petty ways. "Moreover, during an altercation with the youths, he told one of them that "he had the face of a criminal, and would come to a bad end.' As human nature is constituted," says Dr. M'Pherson, "it does not require that a person should be either inherently vicious or criminal to resent such language."

The criticisms I wish to make with regard to Mr. Mudge's statements are these :

(I) That their author is a member of a society which prides itself upon the thoroughly scientific nature of its investigations, and

(2) That although he refers to the "few ostensible successes " of this system, and lightly disposes of them as:

(a) Having been kept for too short a period, and

(b) As not showing a sufficiently bad ancestry, yet on the other hand he does not himself bring forward any large number of unsuccessful cases, observed for a sufficiently long period, in order to substantiate the indictments which he has already made. He contents himself with drawing his conclusions from the few boarded-out youths still at work in the village, after school age-a number which Dr, M'Pherson has further reduced to 3 ( 2 of whom, as has been stated, are mentally deficient), ${ }^{1}$ and then proceeds to generalise with regard to the total number of children boarded-out in Iona by the Glasgow Parish Council after the manner already referred to. I do not know what proportion of mentally-deficient children are actually boarded-out by the Glasgow Parish Council in Iona. In the records sent to me there are of course none.

I should imagine that the same rule would hold good here as in the Industrial Schools and Emigration Homes in England. The point which I have tried to maintain throughout this thesis

1 In this connection Mr. Mudge does not even attempt to show what proportion the "mentally deficient " bear to the rest of the Glasgow boarded-out children. 
with regard to the mentally defective is that these are necessarily exceptions to my argument that good results should follow upon a good environment; in such cases one presupposes failure.

If, however, we rule out the two feeble-minded cases in Iona, as foredoomed to failure, there is left one normal youth, upon whose unsatisfactory behaviour the whole of Mr. Mudge's overwhelming conclusions are based. And even to a novice in the ranks of investigators such reasoning appears absurd.

\section{Conclusions}

Of the 295 records investigated, I have quoted 80 in this section, and I have purposely given a large number of doubtful and unsatisfactory cases because I have wished to show in what circumstances and under what conditions such cases are likely to occur.

On reviewing the manner in which I have dealt with the different Case Books at my disposal, there are many alterations and additions which, in the light of increasing experience, I should like to have made. With a longer period for my inquiry, I should wish to have quoted a far larger number of cases. Also I am conscious that these records are, many of them, inadequate, that my standard is possibly too low, and so forth.

On these and other grounds the following figures (see next page) are open to criticism. But, as I have said before, efficiency is a purely relative term; and my chief object in collecting these records has been to point out the contrast between the child's previous history, with all that it entails, and its later record as influenced by environment. 
Summary of Four Institutions.

\begin{tabular}{|c|c|c|c|c|}
\hline Sources. & $\begin{array}{l}\text { No. of } \\
\text { cases. }\end{array}$ & $\begin{array}{c}\text { Satis- } \\
\text { factory. }\end{array}$ & Doubtful. & $\begin{array}{l}\text { Unsatis- } \\
\text { factory. }\end{array}$ \\
\hline $\begin{array}{l}\text { Y. Emigration Homes, } \\
\text { Girls' Industrial School . } \\
\text { Boys' Industrial School, No. I. } \\
\text { Boys' Industrial School, No. II. }\end{array}$ & $\begin{array}{r}40 \\
129 \\
16 \\
80\end{array}$ & $\begin{array}{l}28 \\
80 \\
11 \\
73\end{array}$ & $\begin{array}{r}8 \\
27 \\
2 \\
7\end{array}$ & $\begin{array}{r}4 \\
22 \\
3 \\
0\end{array}$ \\
\hline Totals & 265 & 192 & 44 & 29 \\
\hline
\end{tabular}

This table summarises the results of four institutions only. Those of the boarded-out children and of the X. Home for Boys are not included, the first because only satisfactory cases were furnished, and the second because the records. were kept for an insufficient period.

Out of 265 cases 192, or 72 per cent., are satisfactory;

44 , or 16 per cent., are doubtful ;

29, or less than I I per cent., are unsatisfactory.

Of the 29 unsatisfactory cases-

8 are definitely mental ;

5 described as "almost deficient, \&c."

And out of 80 records given at length in the above tables, 8 unsatisfactory and doubtful cases were admitted at 12 years or over. I have not any statistics with regard to the proportion of those admitted over 12 to the total number of children, but I think it would be considerably larger. 


\section{SECTION IV}

\section{INSTITUTIONAL TRAINING}

IN this section I wish very briefly to refer to:

I. Some objections raised against institution life; and

II. The advantages of such a life as compared with that of children living below the Poverty Line, e.g. the children of widows on out-relief.

III. A. Employments of children trained in institutions.

$B$. Employments of boarded-out children.

$C$. Employments of children whose parents have been or are at present in receipt of out-relief.

D. Employment of boys.

\section{Some Objections to Institutional Training}

Objections commonly brought against institutional training are the monotony of the life; the lower educational standard than in the elementary schools; the lack of home influence.

Before referring to these points in detail, I should say that I shall consider them rather in relation to their effect on the child's future efficiency than in relation to the comfort or happiness of the child whilst undergoing training.

I. Monotony of the life.- "Under the most favourable conditions, when the responsible officials are men and women of high intelligence and character, these schools may produce certain good results; but the children, except in especial cases, tend to be lacking in general intelligence and the power of observation. . . The normal excitements of ordinary life, excitements which come to all 
children in the natural family, are the most healthy stimulants in the formation of character. The dull monotony of institution life which reduces everything to the dead level of a colourless existence has much to answer for." ${ }^{1}$

"Such training I feel sure is not an effective one, for girls at any rate. It may not be bad for a boy who is to become part of the great industrial machine; but for a girl the question is a different one. She is certain to be sent into an ordinary household as a domestic servant, where initiative, common sense, and powers of observation are far more needed than the power to fit into a great system, and to do what she is told and only what she is told." ${ }^{2}$

The special reference of both these quotations is to Poor Law District Schools; but I have quoted them as illustrating a feeling very prevalent about institutional training in general.

I have already shown that objections which may fit some institutions do not necessarily apply to institutional life as a whole. ${ }^{3}$

A second answer seems to be that although the life of the child in the Scattered Home, or of the child "boarded-out," gives greater opportunity for originality of effort or development of personality, yet the very discipline and routine of institutional life may be necessary for the suppression of bad habits and the formation of good ones. In higher strata of society do we not frequently hear the expression, "Oh! the __'s have sent their boy to boarding-school: they could do nothing with him at home." I do not wish to suggest for a moment that any form of institutional life can be equal to the ideal boarding-out home, but rather that a well-managed institution is to be preferred to the second or third rate separate home, and also that there may be special reasons why certain children will do better in institutions.

1 Margaret Alden, Child Life and Labour, p. 130.

2 Miss E. N. Williams, Report on Condition of Poor Law Children, p. 103.

See above, p. 44. 
With regard to girls, let me refer to the records of the Industrial Schools for Girls already given (p. 27).

Some time ago it was remarked to me by a doctor, whose wife generally engaged servants from an institution in the neighbourhood, that they had no idea of the value of money. But this seems a defect which could easily be rectified, as, for instance, by some plan like that in the Boys' Industrial School (No. 2) of allowing boys to sell the produce of the garden and keep accounts of the same.

2. A lower standard of education.-One hears also the objection that it is impossible to get really efficient teachers in institutions of this kind, that the teaching is not up-to-date, \&c. \&c. I am not sufficiently well informed with regard to the educational work in such schools to be able adequately to discuss this side of the question.

But there are one or two points with regard to the industrial training which I should like to mention :

To quote first from Mr. Cyril Jackson's Report on Boy Labour. In reference to certain returns made to him by London schoolmasters he remarks :

"One headmaster in the East of London divides the boys leaving his school into two 'very distinct' groups-

(I) "The boys who reach the upper classes pass the Oxford Local Junior or the Council's Merit Examination, and pass at once into good places in City offices.

(2) "The boys who find their mental powers taxed to the utmost in the lower classes, and pass out as errand boys, postal and telegraph messengers, van boys, shop boys, \&c." ${ }^{1}$

And to quote from a memorandum by the Rev. D. B. Kittermaster :

"The boy's schooling has been almost entirely book-work. He has been fitted by his years at school for nothing but office-boy work-if he has reached one of the top standards,

1 Royal Commission on the Poor Laws and Relief of Distress, Appendix, vol, xx. ; Report on Boy Labour, by Mr. Cyril Jackson, p. II. 
and, if not, for no sort of work at all. Must we not agitate then for a large increase of industrial training in the schools?" 1

It is the members of group 2, the boys who never reach the fifth standard, but find their mental powers taxed "to the utmost in the lowest classes," who are saved from "passing out as errand boys, van boys and shop boys," \&c., by just the kind of training received in an Industrial School, and who are the most likely to become the efficient skilled and unskilled workers of the future. The day of Juvenile Labour Exchanges and After-Care Committees has now dawned. But hitherto it has been an advantage of institutions over ordinary schools that there has always been someone whose duty at any rate it was to see that every child had a suitable start in life.

3. Lack of home influence.-Miss Williams in her Report on "Out-Relief Children" says :

"We may well ask, would not the pauper child be better in an institution of this kind (Ponteland), rather than in an average Out-Relief Home?

"I take it that what every child wants, and what every home which is reasonably good gives, is a certain stability in life, a sense that there is one place, one little group, to whom it stands in a unique relation, and who regard it as they regard no one else, a point to which under any circumstances it can turn.

"When a pauper child goes out to work is the time when the need of this relation is most keenly felt, and I have had it borne in upon me during the last few months that many of the children who fall under the influence of unsatisfactory relatives, when they go out from the Poor Law Institution to a situation, do so because they want this very thing, something that belongs to them and them only." 2

Of the six institutions whose records I have investigated,

1 Ibid., p. 154.

2 Report on Poor Law Children, p. 85. 
the two which should be least touched by this criticism are those whose children are boarded-out in working-class homes, namely, the Y. Emigration Homes and the Glasgow Parish Council.

Should the home they provide be a satisfactory one, it should be able to supply the child with just that sense of stability and closeness of tie that Miss Williams thinks so desirable.

The Commissioners signing the Poor Law Majority Report say:

"One grave defect which we have noticed is the absence of systematic record as to what becomes of the children after passing from the care of the Guardians, generally at the early age of fourteen.

"In a few cases such records are kept, but in the great majority of Unions the Guardians keep no record of their children, and it is a matter of chance whether some individual guardian or official keeps in touch with a child sufficiently to know what becomes of it after the lapse of a year or two. In many of the schools we are glad to know that the superintendents have made themselves so trusted that the children will turn to them in times of difficulty, but we think that something more than this is needed. It is not sufficient to send a child of fourteen to a situation which may prove unsuitable and leave it there to look after itself." 1

Let me contrast this with the descriptions already given of the efforts made by both the superintendents of the Girls' Industrial School and of the Boys' Industrial School (No. 2) to keep in touch with the children who have passed through their hands, not only for one, two, or three years, but for the rest of their lives if possible. And if we look back at the girls' records and see how repeatedly we come across the phrase, "Was present at the Re-union"; "Brought her baby to the Re-union"; "Spent her holidays at the School three years

1 Majority Report, Part iv. ch. 8. 
running," \&c., and remember the expressions of loyalty and affection for their Superintendent expressed in the letters of Old Boys from School No. 2; or if we realize, what I have tried to show, that the X. Home for Boys is a home in the ideal sense of the word, then it is made clear to us that the difference which exists between these and the pauper children of whom Miss Williams speaks is due simply to a lack of thoughtful after-care.

Yet it is certain that even were a system of compulsory after-care established for a definite number of years, this would not in itself create the feeling "that there is one place, one little group to which these children stand in a unique relation which they regard as they regard no other person, and to which under any circumstances they can turn." How far an institution can provide this depends very largely on the personality of its Head.

\section{The Advantages of Institution Life as COMPAREd WITH THE LIVES OF CHILDREN ON OUT-RELIEF 1}

In endeavouring to make some slight comparison between the life of institution children and the life of some other group of children, in regard to their future general efficiency, I have chosen the children on out-relief for several reasons. It is partly because I wished rather to compare these institution children with children of a more respectable class than with children of the class from which they themselves have sprung. Presumably few widows on out-relief are members of Class A ; for out-relief should only be given to people of respectable character and antecedents.

But chiefly because, desiring to make some comparison between the mode of life of two different groups, and between the efficiency of the child and the efficiency of the parent in

1 I shall speak only of some drawbacks in the life of Out-Relief Children-the obvious possible advantages are taken for granted. 
each group, and having no time to undertake any original investigation on these lines, I have been very glad to make use of the information supplied in the section dealing with children on out-relief in Miss E. N. Williams' "Report on the Conditions of Children who are in receipt of the various forms of Poor Law Relief in England and Wales." 1

First, then, as to the character of mothers in out-relief families. I have said that we naturally should not expect to find many out-relief families in Mr. Booth's Class A-a class which includes "the lowest kind of occasional labourers, street-sellers, criminals and semi-criminals." The majority will probably be found in classes B, C, and D, though if we rank them according to the wage-earning capacity of the husband when alive, some may be members of $\mathrm{E}$ and $\mathrm{F}^{2}{ }^{2}$

Miss Williams has classified her out-relief mothers, according to character and intelligence, as follows:

\begin{tabular}{|c|c|c|c|}
\hline Class I. & Class II. & Class III. & Class IV. \\
\hline $\begin{array}{l}\text { Women above the } \\
\text { average, capable } \\
\text { and trustworthy, } \\
\text { able to give their } \\
\text { children an excel- } \\
\text { lent training, to } \\
\text { plan for their future } \\
\text { well-being, and to } \\
\text { sacrifice a present } \\
\text { gain to a future } \\
\text { good. }\end{array}$ & $\begin{array}{l}\text { Women of lower } \\
\text { morale, good in in- } \\
\text { tention, but less } \\
\text { able to carry out } \\
\text { their intentions or } \\
\text { to cope with re- } \\
\text { sponsibilities, often } \\
\text { wom en wh os } \\
\text { health has failed, } \\
\text { and whose force of } \\
\text { character has not } \\
\text { given them the } \\
\text { power to rise above } \\
\text { it. }\end{array}$ & $\begin{array}{l}\text { Include the slovenly } \\
\text { and the slipshod, } \\
\text { women of weak in- } \\
\text { tentions and often } \\
\text { of weak health, } \\
\text { who are not able } \\
\text { to make the most } \\
\text { of their resources; } \\
\text { the comfort of their } \\
\text { homes falls even } \\
\text { below their means. }\end{array}$ & $\begin{array}{l}\text { The really bad } \\
\text { mothers - people } \\
\text { guilty of wilful } \\
\text { neglect, sometimes } \\
\text { drunkardsor people } \\
\text { of immoral charac- } \\
\text { ter. (No woman } \\
\text { has been put into } \\
\text { this class of whom } \\
\text { it was not fairly } \\
\text { evident that she } \\
\text { was unfit to have } \\
\text { the charge of chil- } \\
\text { dren.) }\end{array}$ \\
\hline
\end{tabular}

She gives also, as the proportion of out-relief mothers belonging to each class, the following estimates:

1 Royal Commission on the Poor Laws and Relief of Distress, Appendix, vol. xviii., rgog.

${ }^{2}$ See above, p. $\mathbf{x}$. 


\begin{tabular}{|c|c|c|c|c|c|}
\hline & $\begin{array}{l}\text { Percentage } \\
\text { in Metro- } \\
\text { politan } \\
\text { Unions. }\end{array}$ & $\begin{array}{l}\text { Percentage in } \\
\text { Extra-Metropoli- } \\
\text { tan and Urban } \\
\text { Unions. }\end{array}$ & $\begin{array}{l}\text { Percentage in } \\
\text { Rural and } \\
\text { Semi-Rural } \\
\text { Unions. }\end{array}$ & $\begin{array}{l}\text { Extended } \\
\text { Percentage } \\
\text { for the } \\
\text { Kingdom. }\end{array}$ & $\begin{array}{l}\text { Extended } \\
\text { Number } \\
\text { for the } \\
\text { Kingdom. }\end{array}$ \\
\hline Class I & 30 & 27 & 33 & 29 & I6.700 \\
\hline "1 2 & 43 & 40 & 42 & $4 I$ & 23.300 \\
\hline & 15 & 18 & I9 & 18 & 10.300 \\
\hline ", 4 & 12 & I5 & 6 & 12 & 6.800 \\
\hline
\end{tabular}

It is obvious that any advantage that the children of the I 2 per cent. of mothers who fall into Class IV. may reap from the possession of a " home" must be more than counteracted by their unsatisfactory environment and mother's character. And with regard to the children of the Class III. mothers, will the advantage of the home life make up for the inefficiency of the parent? an inefficiency which when it reappears, as it is likely to do, in the children, may be the result of heredity, but more probably of the forces of suggestion and imitation; in fact of general adaptability to the environment.

As to the food of out-relief children : the diets of the outrelief children have been classed as follows :-

"CLASS I.-In this class the meals are regular, and at least one meal daily consists of cooked food. An example of the diet which would qualify for this class is meat and potatoes on Sundays; on other days, fish, eggs, soup, rice and other puddings, bread baked at home (York).

"CLASS II.-Here, too, the meals are regular, but they are not always prepared. This is often because the mother goes out to work, leaving a dinner of bread and margarine or dripping on the table for the children, and does not trouble or cannot always afford to give them a cooked supper when she comes home. A typical case provides ' a hot dinner four days a week' if possible, consisting of rice, suet, or other puddings, little meat. On the other days the food would consist of bread and tea. 
"ClasS III.- The families in this class are those whose meals are apt to be irregular, either owing to a definite shortage of food, which makes it necessary to go without, or owing to a habit of eating whatever food is obtainable at any hour of the day. There is still a certain amount of cooked food. An example of this class is, 'sometimes twopenny worth of meat and potatoes, Quaker oats, bread and lard or dripping.' Also, ' a turnip and some potatoes for dinner, sometimes only bread; meat and milk very rare,' \&c.

"CI.ASS IV.-Here the food is definitely bad. It is irregular and seldom, if ever, prepared. A diet of this type consists of (I) 'mostly bread, tea, and scraps'; (2) 'much bread, occasionally a halfpenny worth of soup'; (3) 'mostly bread, potatoes when they can be afforded ' (York)." 1

Percentage of Children in each Class for each Group of Unions.

\begin{tabular}{|c|c|c|c|c|c|c|c|c|}
\hline & & & & & $\begin{array}{l}\text { Metropolitan } \\
\text { Unions. }\end{array}$ & $\begin{array}{c}\text { Extra } \\
\text { Metropolitan } \\
\text { and Urban } \\
\text { Unions. }\end{array}$ & $\begin{array}{l}\text { Rural and } \\
\text { Semi-Rural } \\
\text { Unions. }\end{array}$ & $\begin{array}{c}\text { Extended } \\
\text { Percentage } \\
\text { for the } \\
\text { Kingdom. }\end{array}$ \\
\hline Class I & . & . & . & . & 43 & $4 \pi$ & 24 & 36 \\
\hline ", 2 & . & . & . & . & 23 & 30 & 37 & $3^{2}$ \\
\hline "I 3 & . & . & . & . & 20 & 12 & 25 & 17 \\
\hline ", 4 & . & . & . & . & 14 & 17 & I4 & 15 \\
\hline
\end{tabular}

Miss Williams remarks: "I think we may safely decide that the children in Class IV. are all unsuitably, if not insufficiently fed. Bread and tea can never provide a suitable or even a sufficient diet for growing children. And if we regard the Unions investigated as a sample of the whole country, this means that 15 per cent., or about 27,100 children, are being fed on little else than bread and generally milkless tea. This is not a really cheap diet. It is a poor one to 1 Report on Children in receipt of Poor Relief, p. $6 \mathrm{r}$. 
'grow out of,' and is very unproductive of muscular or nervous energy.

"Thirty-two per cent., or 55,500 children (in Classes III. and IV.), are irregularly fed; of the remaining 68 per cent., or I I 5,700 children, placed in Classes I. and II., it is very difficult to say what proportion of them are sufficiently fed."

Let me add the following observations of Miss Williams on the after-care and employment of children of school age:

"In certain Urban Unions a good many out-relief children of school age were employed out of school hours and on Saturdays. Altogether we have notes of 66 so employed, 52 boys and 14 girls. Except for II children (5 boys and 6 girls) working in the Bradford mills, all are employed either as errand boys and girls, selling newspapers, \&c., in the streets, taking round milk-the boys also as golf caddies and as barbers' boys, \&c.

"In Lambeth 13 boys are employed in these various ways. A very large proportion of these, i.e. 35 per cent., are described as dull; and though the numbers are too small to draw any conclusions from them, yet it should be remembered that milk and newspaper boys often cannot get as much sleep as growing children need, while the same is true of latheringboys in barbers' shops who are kept very late at night. In Liverpool I7 boys work in much the same employment as the Lambeth boys, and 3 per cent. of them are stated to be dull or very dull. In Bradford I I children work as halftimers in the mills. These children work five hours at a stretch, and attend school the other half of the day. . . . I can hardly believe that a child of twelve working for five hours in the mill can profit much by his education in the other part of the day. ... The schoolmasters at Rochdale were loud in their condemnation of the system, saying that the children were not able to learn, and became quickly demoralised.

"No Board of Guardians, so far as my investigations go, takes any interest whatever about the placing and starting in 
life of boys who have had outdoor relief, nor does it try to help them to any technical training. . . . For a boy, out-door relief stops at 14, and he turns to the first job at which he can earn. Most likely this will be one which will lead to nothing; it may be street-selling of some kind, it may be an errand or van boy's job. When it is over, he finds or tries to find another, probably also leading to nothing; and so he drifts on. I have no numbers or figures for these statements, but in the cases I visited personally I saw many lads in this process of being manufactured into casual labourers." 1

To sum up, I have quoted freely from Miss Williams' report, to illustrate four of the principal drawbacks of the outrelief system as it affects children :-

r. Unsatisfactory character of many mothers.

2. Insufficient food.

3. Employment of children of school age.

4. Want of after-care.

There are others besides these, such as-

5. Over-crowding.

6. Unsanitary surroundings.

7. Want of proper medical supervision.

It seems plain that the six and a half thousand children estimated as suffering from drawback No. I, i.e. the possession of Class IV., mothers (bad, neglectful, drunken, and often immoral women, described as unfit to have the charge of children) will inevitably suffer also from drawbacks $2,3,4,5$, 6 , and 7. The 10,000 odd children of Class III. mothers (the slovenly and slipshod, the comforts of whose homes fall even below their means) will also most probably suffer from insufficient food, over-crowding, unsanitary surroundings, want of proper medical attendance, and may be employed under 14 years.

It is possible that the Class II. children may suffer from one or any of these disadvantages.

1 Report on Children in Receipt of Poor Relief, p. 87. 


\section{Institutional Training}

The Class I. children will probably escape all, even No. 4. The point that I wish to insist upon is, not that a large proportion of these children would necessarily fare better in institutions (in the ideally managed institution, I think they would) ; but only that, in the face of such obvious disadvantages, they cannot be so well equipped for their start in life, physically, mentally, or even morally, as the majority of institution children.

And when we talk glibly of the "home tie" supplied in the lives of these 17,000 children by the mothers of groups 3 and 4 , is there not a risk that we shall sacrifice a very tangible good, to a sentiment which we may be very far from being able to give satisfactory effect to?

\section{EMPLOYMENT}

Nature of Employment of Out-Relief Fathers.

An interesting attempt was made, in connection with the Poor Law Commission, to discover the employments previously followed by the fathers of the families in receipt of out-relief. The facts ascertained have been roughly classed under the four divisions of - commercial, skilled, unskilled, and "other employments" (very doubtful cases being omitted), and the results arranged as percentages.

Commercial includes all work connected with buying and selling from factoring to hawking.

"Other Employments" includes army, navy, and other public services, policemen, as well as all forms of domestic service.

The table is given on the following page. 
Employments of Fathers in Percentages; Unions of Lambeth, Paddington, St. George's, Bradford, Derby, Liverpool, MerthyrTydfil, Nervcastle, Rochdale, West Derby, York, Mitford and Launditch, and Warwick.

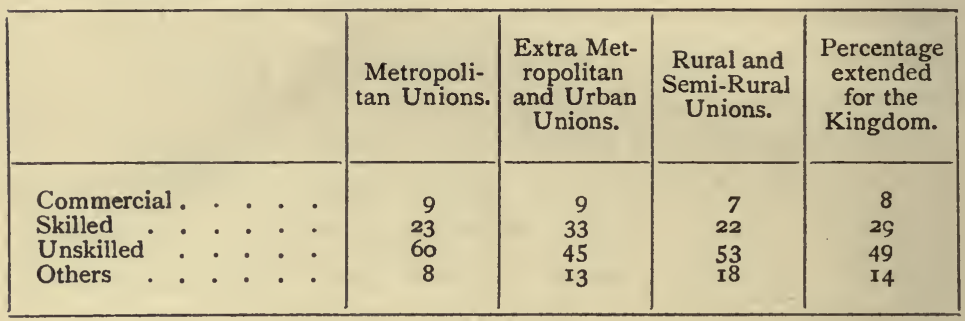

Employments of Out-Relief Sons (over I4) in Percentages.

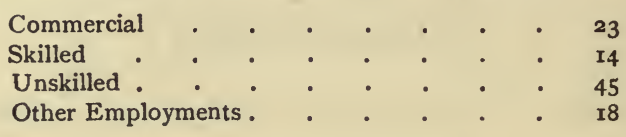

\section{Nature of Employment of Out-Relief Sons.}

"In the Unions of Bradford and Paddington, all the sons of out-relief families are in unskilled employments.

"Leaving out Rochdale, the greatest proportion of sons of out-relief families in skilled employments is at York, where there are 2 I per cent. Taken as a whole, 29 per cent. of the fathers of out-relief families are skilled artisans, while only I4 per cent. of their sons are following or preparing to follow skilled employments. Doubtless this is partly due to the fact that, when a lad becomes a skilled workman, his wage, so long as he remains at home, will put the family income above the maximum for out-relief. This is borne out by the fact that in Bradford and Paddington, two of the strictly administered Unions, there are no sons in skilled employments.

"At the same time, in the course of my visits to the outrelief homes, I was struck by the number of ill-nourished, 
ill-grown lads whom I saw, who were evidently living on odd jobs, and on the road to join the army of casual labour." 1

The table summarising the occupations of these out-relief children is based on 900 odd cases.

I had hoped to make a similar comparison between the occupations of institution children and the occupations of their fathers, but on going through my records I have found only 23 cases where the occupation of the father is actually stated. $^{2}$

In many cases where the record of the son is particularly satisfactory, the father is referred to as "a drunkard" or "in gaol," or " dead and the character of the mother undesirable," or again both parents are referred to as "disreputable," and the home as a bad one, and so on, but the occupation is not given.

I feel that a comparison between a summary of 900 cases and a summary of 23 would be no comparison at all, so I have not troubled to make out a similar table of these occupations, but give the list as it stands.

Occupation of Father.
I. Hawker
2. Clerk*
3. Tramp . . . . Grocery Salesman.
4. Iron Roofer . . . . Drapery Salesman.
5. Spinner . . . . . Chauffeur.
6. Carter. . . . . Railway Clerk.
7. Labourer . . . . . Chauffeur.
8. Spinner . . . . . Motor Car Demonstrator.
9. Labourer . . . . . Chief Ship's Steward.
Io. Butcher . . . . . Nursery Gardener.
II. (Step-father) Furnaceman* at 36 s. Chargeman at Iron Works at $£ 6$.
12. Engine Driver . . . Cattle Farmer.
I3. Labourer . . . . . Professional Footballer.
14. Company Promoter* . . Army Bandsman.
I 5. Company Promoter*. . . Soldier.

Occupation of Son.

1 Report on Poor Law Children, Miss E. N. Williams, Section X.

2 I refer only to the 80 records quoted, of the 295 investigated. In the other cases I noted down only the character of the child's record. 
Occupation of Father.

16. Bricklayer

17. Bricklayer*

18. Engineer*

19. Labourer .

20. Labourer .

2I. Butcher*

22. Bricklayer*

23. Soldier
Occupation of Son.

- Iron Worker.

- Army.

- Labourer (mental defect).

- Soldier.

- Telephone Co. employee.

- Army.

- Labourer.

- Farmer.

With regard to this list, I believe if a calculation were to be made as to skilled trades, it would work out at about twelve fathers and ten sons. It would be unsafe, however, to base any conclusions on such an estimate for a variety of reasons. Three of the sons, for instance, are engaged in particularly good commercial occupations.

Again it will be noticed that I have marked with an asterisk cases where the fathers are engaged in skilled trades and the sons in unskilled. These fathers are, without exception, men of unsatisfactory character.

And, even if I had attempted to take as my standard of efficiency the skilled worker-which I have not-it is obvious that, regarded from most points of view, the respectable unskilled worker is of more value to the community than the disreputable skilled one. The same conclusions may, of course, be drawn with regard to the out-relief fathers and sons, but it is not so probable that in these families the father, when alive, was unsatisfactory, whereas in a large proportion of these institution cases the father is still living, but is not regarded as a fit guardian for the child.

The inference that I would draw from a comparison of this kind is, that the out-relief son starts his industrial life often on a lower plane than his father did, whilst the position of the institution child, in the majority of cases, is very distinctly higher than that of his parents.

The following table of Birmingham Boys' occupations is taken from the Report on Boy Labour by Mr. Cyril Jackson. 
The original table is filled in for the consecutive ages from 14 to 20 of 135 boys; I have quoted those at 15 and those at 20. From the difference in the two totals it would seem that many of the boys by the age of 20 are absorbed in other occupations than those given. I have then endeavoured to make out a somewhat similar table, stating the occupations of I 30 institution boys. I realise that the comparison is not a very satisfactory one, as I have not been able to state at what particular ages the boys were engaged in these trades, but roughly, that their ages varied from I 5 to 30. About half these boys are natives of Birmingham; the rest are from the North of England Industrial School, and 9 are Glasgow Parish Council children. No children from the Emigration Homes are included.

Birmingham Boys' Occupations (1 35 cases).

\begin{tabular}{|c|c|c|c|c|c|c|}
\hline & & & $\begin{array}{l}\text { Number. } \\
\text { Aged } \text { I }_{5} \text {. }\end{array}$ & Percentage. & $\begin{array}{l}\text { Number. } \\
\text { Aged } 20 .\end{array}$ & Percentage. \\
\hline Skilled & . & . & 18 & 13.4 & 19 & 28.4 \\
\hline Clerks & . & . & I5 & II. 2 & Io & 14.9 \\
\hline Low Skilled & . & . & 29 & 21.7 & 13 & 19.4 \\
\hline Carmen . & . & . & $\mathrm{I}$ & 0.7 & 3 & 4.5 \\
\hline Van Boys. & . & . & 3 & 2.2 & $\ldots$ & $\ldots$ \\
\hline General Labo & arers & . & 40 & 29.9 & I6 & 23.8 \\
\hline Errand Boys & . & . & 18 & 13.4 & $\ldots$ & $\ldots$ \\
\hline Post Office & . & . & Io & 7.5 & $\mathbf{I}$ & I. 5 \\
\hline Army . & . & . & $\ldots$ & $\ldots$ & 5 & $\ldots$ \\
\hline \multicolumn{2}{|c|}{ Total } & . & 134 & $\ldots$ & 67 & $\ldots$ \\
\hline
\end{tabular}

My own table showing the occupations of I 30 boys from institutions will be found on the next page. 
Institution Boys' Occupations ( 130 cases). Ages, I5-30.

\begin{tabular}{|c|c|c|}
\hline & Number. & Percentage. \\
\hline $\begin{array}{l}\text { Skilled }: \\
\text { Clerks } \\
\text { Low Skilled }: \\
\text { Carmen. Van Boys } \\
\text { General Labourers } \\
\text { Errand Boys. Post Office } \\
\text { Army and Navy } \\
\text { Gardeners. Grooms } \\
\text { Shop Assistants } \\
\text { Sailors } \\
\text { Salesmen : }:\end{array}$ & $\begin{array}{r}84 \\
5 \\
6 \\
\ldots \\
8 \\
\ldots \\
12 \\
7 \\
2 \\
3 \\
3\end{array}$ & $\begin{array}{r}64.6 \\
3.8 \\
4.6 \\
\ldots .1 \\
6.1 \\
\ldots .2 \\
9.2 \\
5.3 \\
1.5 \\
2.3 \\
2.3\end{array}$ \\
\hline Total & 130 & $\ldots$ \\
\hline
\end{tabular}




\section{SECTION V}

\section{CONCLUSIONS}

IN introducing the subject of this thesis, reference was made to the confusion in some minds as to the terms Heredity and Environment; and an attempt was made to show, following Professor Thomson, that they are often almost indistinguishable.

The extreme position adopted by some Eugenists was then stated; and by means of the records collected I have endeavoured to show the importance of environment as a determining factor of character and industrial capacity.

Some comparison was then made between the life of the institution child and the life of the child whose previous homesurroundings and parents' history are of a more satisfactory nature, namely, the child of the widow on out-relief; and it was shown that there are some great advantages in the life of the institution child when the institution is reasonably conducted.

It will be seen, on referring to Section III., that 72 per cent. of the records investigated proved satisfactory, and that of the 29 distinctly unsatisfactory cases, 13 are mental or "almost deficient."

Most of these satisfactory records are of young men and women whose position in life is now much above the "poverty line" referred to in Mr. Booth's classification.

One or two cases may probably fall into Class D, but the large majority will be members of Groups E, F, and G. The majority of the parents, on the other hand, were undoubtedly members of Class A.

I would urge that it is only by producing accurate records 
of this kind, extending, if possible, over a much longer period, that those who have the welfare of the institution child at heart, can hope to refute the theory that larceny, drunkenness, prostitution, and other forms of vice, are transmitted with the same regularity from one generation to another as characters of mental defect. For if the part played by environment in the formation of the child's character is as small as some Eugenists would have us believe, how can we account for the marked contrast displayed between the early and later history of these children?

The following contentions of course may be raised:-

I. That it is not possible to base conclusions upon records kept for periods of under, say, 20 years.

2. That in any case the vicious characters are lying latent to be reproduced in a future generation.

With regard to the first of these criticisms, the inadequacy of many of these records has already been acknowledged; and although the object of this thesis has been to prove the very definite part played by environment in the development of character and efficiency, as illustrated by these records, I have never attempted to maintain the impossible position that every one of these young people, so far classed as satisfactory, will therefore remain satisfactory until the end of their lives.

I have, however, quoted various authorities to prove that the unemployed workmen of middle life have frequently been found to originate in those numberless boys who drift from the moment of leaving school; and I have thought it fair to infer that the boy, satisfactorily accounted for during the first five years of his adult life, may well become the reliable workman of 40 or 50 .

As to the length of time for which records should be kept, two, if not three of the institutions whose books I have investigated, will, in the course of another Io or 15 years, be able to produce records of 20 and 30 years' duration. And with regard to the numerous institutions where either 
no records at all, or quite inadequate ones are kept, it seems almost unnecessary to suggest that it would be to their own advantage, if instead of vague statements with regard to the probable efficiency of most of their children, they could produce full and adequate records wherewith to meet the criticisms at present being hurled at the whole system of which they themselves form a part. ${ }^{1}$

To refer now to the second criticism, viz., that the vicious characters will inevitably reappear in a later generation. Even if this could be proved to our satisfaction, is it easy to conceive the extent to which a community will have benefited, which has raised but one generation of respectable and efficient men and women, from a generation of paupers and degenerates? Let us admit the possibility of the so-called hereditary taint reappearing in certain cases in the third generation, and then try to realise the difference which that intervening race of relatively efficient men and women will have made in the whole outlook and environment of these possible victims of Heredity - the children of the third generation.

If the parent and environment of the child of the second generation were equally bad, so for the child of the third generation will they be good. In the first case the parent was probably himself the outcome of his environment and not its cause, in the second he has to a great extent created it. In the one case the undesirable characters in the child were stimulated and suggested by its environment; in the other, stimulus and suggestion will alike be missing.

And if in the face of an unsympathetic environment the "hereditary taint" still continues to persist, let us again step in and rescue the child of the fourth generation from the inevitable disadvantages which such a persistence will create.

Such a policy is full of hope. For let us recall the biological conclusions of Professor Thomson: "variations,

1 As an example of a satisfactory system of " after care," see Appendix C. (Rules for District Visitors of the Association for Befriending Boys.) 
although more or less transmissible, are not always transmitted; where a predisposition is inherited, it does not necessarily follow that it will be expressed in developmentif it does not find appropriate nurture it will not express itself; and eventually, whether it find expression or not, it may die away altogether."

So our race of hereditary paupers and criminals will form, as generation follows generation, an ever-increasing minority, until eventually - who knows ? - they may be crowded out altogether by the mere force of a beneficent environment. 


\section{APPENDIX A.}

\section{EXTRACTS FROM ANNUAL REPORT OF THE ASSOCIATION FOR BEFRIENDING BOYS ${ }^{1}$}

OF the boys reported upon, $I, 3$ I 8 , or 56.85 per cent., are satisfactory, as against 1,310 , or 58.7 per cent. in 1909 . This is a drop of 2 per cent., and consequently rather disappointing. These numbers, however, must vary from year to year; and a movement of 2 or 3 per cent. upwards or downwards is not very important if the number of boys reported upon is taken into account. The other numbers show but little change. As we pointed out last year, it by no means follows that because 58 per cent. are reported satisfactory the remaining 42 per cent. are unsatisfactory. This is by no means the case. There are a good many boys about whom reports have not been received recently; then there are the boys on the Exmouth, and in two Homes in South London, who, as long as they are in these institutions, are reported upon directly to the Guardians by the authorities. A very large proportion of these is doing well. Even if those who are classed as "lost sight of" are counted as unsatisfactory, which, of course, by no means follows, and added to those we know are unsatisfactory, the number is only 196 , or just over 6 per cent. This is an astonishingly good result, and would be regarded rightly as extraordinary amongst any set of 2000 boys in the kingdom. It is one more proof-if proof were required - of the excellent training given in the much-decried Guardians' schools. If those people who consistently and without knowledge are trying always to bring these schools into disrepute could see for themselves the products of the schools, we think that less would be heard of the drawbacks and inferiority of the schools they are pleased to term "barrack." The boys from the Guardians' schools

1 The work of this Association in the first instance is the care of boys up to the age of 20, coming from the Poor Law Association (Metropolitan). 
are in no way inferior to the average elementary school boys; in fact, they are superior, for they have the benefit of excellent training, good discipline, good food, and good lodging, and physical training, which are not enjoyed to any great extent as a rule by the boys at the elementary schools.

The difficulty of keeping in touch with the boys in the Royal Navy and Merchant Service does not grow less, and is the chief reason why the percentage of "no late reports" is unduly large and slightly higher than in 1909.

\section{LETTER FROM HEADMASTER OF THE POPLAR TRAINING SCHOOL}

The Guardians have received the Annual Reports from the Association for Befriending Boys upon 279 boys placed out from this Parish, which are summarised as follows :-

\begin{tabular}{|c|c|c|c|c|c|c|}
\hline Satisfactory . & • & - & - & & - & 127 \\
\hline Fair . . & - & . & • & & . & ro) Should be re- \\
\hline Unsatisfactory & . $\quad$. & . & • & 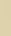 & - & $9\}$ garded as not \\
\hline Returned to Guar & rdians & . & . & 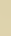 & . & 5 creditable. \\
\hline No late report & - $\quad$. & - & . & 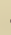 & - & $3^{x}$ \\
\hline Not yet reported & - & . & • & 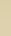 & - & I \\
\hline Lost sight of & - $\quad$. & . & . & . & - & I7 \\
\hline Reported directly & to Gua & lians & - & & . & 74 \\
\hline Emigrated & . $\quad$. & . & . & & . & 4 \\
\hline Dead . . & - & - & • & & . & I \\
\hline & & & & & & 279 \\
\hline
\end{tabular}

Of these, 29 will be 21 years of age in 1912.

\section{LETTER FROM THE SECRETARY OF SIR JOSIAH MASON'S ORPHANAGE}

When children leave this institution they go either to situations found for them or to the care of their own friends and relatives. Generally speaking, we keep in touch with them for years afterwards, and the Trustees have arranged for their "after-care."

From my record of "old boys" under 2 I last year, I find that very few are not in satisfactory situations. The following figures may prove interesting :- 


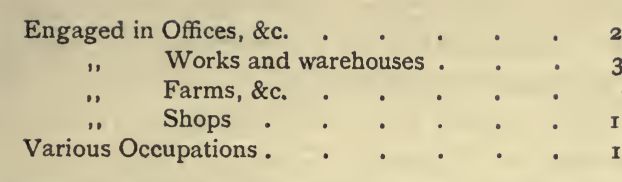

Satisfactory.

23

30

7

14

13

In several cases the cause of non-success is indifferent health. Several who have been unsatisfactory at first have done well in another sphere of labour.

\section{REPORT FROM THE SUPERINTENDENT OF THE PONTELAND COTTAGE HOMES}

These Homes have been open eight and a half years. We have sent out into situations about 110 boys and 70 girls. Of these, 2 boys and 2 girls may be said to have done badly. Of the others, 75 per cent. may be said to have done excellently.

The remainder includes some who ought to have done better; but it also contains some who have done better than one expected; and, on examination, I think the 25 per cent. of (only ?) moderately successful cases contains a greater number of those who have done better than expected than of those who have done less well than they should.

\section{DUNDEE BOARDED-OUT CHILDREN}

\section{From a Report on the Boarding-out of Pauper Children, 1904.}

During the five years from May $15^{\text {th, }} 1899$, to May I $5^{\text {th, }} 1904$, the number of boarded-out children was $354,-\mathrm{I} 52$ boys and 202 girls. Of these, $\mathrm{I} 72$ are still chargeable and boarded-out, leaving 182 who have ceased to be chargeable. Of the 182,153 (55 boys and 98 girls) are now self-supporting, and, so far as known, doing well. Of the remainder, 23 were either sent to an orphanage owing to the death of guardians, or to hospital owing to illness, and others have died. Two alone are known to have turned out badly.

Going farther back than these five years, there is only one case of a former boarded-out child who is now chargeable to the parish, the cause being imbecility, and among the boarded-out children 
now chargeable to the parish, there is one illegitimate boy whose mother had been boarded-out and brought up by the parish. Three boys now boarded-out are beyond the age of 14 , and are learning trades. They reside in a Working-Boys' Home where some 20 boys are boarded, and are employed with firms outside. There is always an opening in this Home for any boy who desires to learn a trade. The practice of the Parish Council is to assist the boys with a small aliment so long as their earnings are under 5/- a week, and, after this wage is reached, the authorities in charge of the Home do not look for any further pecuniary assistance beyond a supply of clothing which is given them until they can do without it. The system has worked very satisfactorily for a number of years, and the boys are employed as bookbinders, upholsterers, cabinet-makers, \&c. They go out and in to the Homes at their leisure, having a fixed hour for returning at night. They accompany the Superintendent of the Home to church on Sundays, and they attend evening classes on week nights. Their holidays they are in the habit of spending with their old guardians.

\section{SOUTHWARK BOYS' AID ASSOCIATION}

[Object:-The after-care of the orphan and homeless boys from the Poor Law schools of the Southwark Union, including-

(I) Finding a suitable home for each boy, if possible in a working-class family.

(2) Finding work suited to the capacity of each individual boy; if possible in a skilled trade.]

\section{Report for Twelve Months ending Michaelmas I 9 I I.}

During the twelve months the Association has been in touch with 219 boys and children, 87 of these being new boys: -28 from the Hanwell Schools, 12 from the Orpington School, I9 from the Guardians direct, I4 from the training-ship Exmouth and I4 from other sources.

Of these 87 new boys 22 are disabled:-14 physically, 6 mentally, and 2 both physically and mentally.

Special care and attention has also been given to 50 old boys who are disabled either in mind or in body. 
During the twelve months work has been found for 60 boys, of whom 10 have been placed twice over and 2 more than twice, making 74 placings in all, as shown by the summary below :-

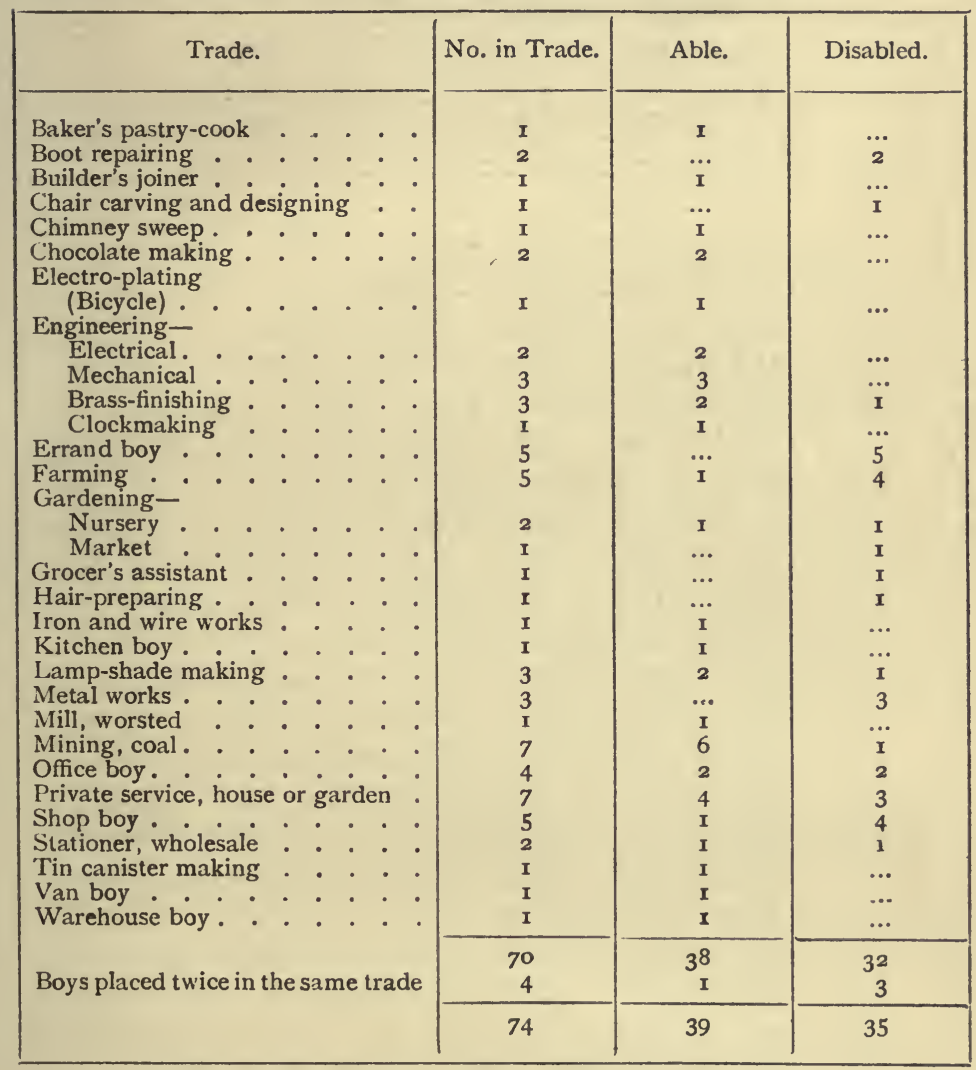

7. EXTRACT FROM THE ANNUAL REPORT OF

A HOME FOR WORKING BOYS (AFTER LEAVING AN ORPHANAGE)

List of the Occupations of the Employers of Boys in the Home, with Notes on their Work.

r. Brasscasters ; learnt the trade.

2. Metal merchantr; rough warehouse. 
3. Goldbeater; at the trade.

4. Boot manufacturer; learnt the trade.

5. Silversmiths; learning the trade.

6. Bedstead works; learning the trade.

7. Art metal works; learning the trade.

8. Art metal works; learning the trade.

9. Art metal works; learning the trade.

Iо. Brassfounder; learning the trade.

II. Silversmiths; learning the trade.

I2. Brush works; learning the trade.

13. Art metal works; learning the trade.

14. Wire workers; learning the trade.

15. Bird cage works; learning the trade.

I6. Metal turners, \&c. ; learning.

I7. Bird cage works; learning the trade.

I8. Soap works; learning the trade.

19. Cabinet works; learning the trade.

20. Electrical works; learning the trade.

2 r. Gold beater; learning the trade.

22. In the Home, driving float.

23. Cabinet works; learning the trade.

24. Electrical works; learning the trade.

25. Brassfounders; learning the trade.

26. Jewellers; learning the trade.

27. Cabinet works; learning the trade.

28. Art metal workers; learning the trade.

29. Cabinet works; learning the trade.

30. Candle works; learning the trade.

31. Jeweller; learning the trade.

32. At home.

33. Soap works; learning the trade.

34. Silversmiths; in the warehouse.

35. X Silver Co.; at the trade.

36. Printer; to be apprenticed.

37. X Silver Co.; at the trade.

38. Shoeing smith; at the trade.

39. Electrical works; at the trade.

40. Motor tank manufacturers.

4I. Electroplate manufacturers; at the trade. 


\section{FROM THE REPORT FOR 1911 OF THE SWANLEY} AND FARNINGHAM HOMES FOR BOYS

"What becomes of your boys?"

"Are they as well fitted for the battle of life when they leave the Homes as other boys of their age?"

"Does the training they receive enable them to maintain themselves in the world?"

These are the questions we are often asked, and rightly so, for a Home which has not as one of its fundamental, underlying principles the absolute necessity for giving to every boy who passes through it such training as would fit him to earn his own living, can never make any really powerful appeal to clear-headed, practical men and women.

We can claim for the Homes for Little Boys that from their foundation this end has been held steadily in view. The choice of a trade, the boy's life in the workshop, and his establishment in some suitable situation, are matters of the first importance with us.

As soon as a boy is I 4 , or has passed the VIIth standard, he is apprenticed to some trade, and every care is taken that he shall follow one for which not only his peculiar bent but his physique and aptitude especially fit him. His choice is a wide one.

Many trades are taught in the Homes. Printing, farming, gardening, poultry - keeping, tailoring, shoemaking, engineering, carpentering, plumbing and painting, and baking. In addition to these, many boys go into the navy and army and into the mercantile marine. Some of our band boys continue their studies in that direction, and have taken good positions in the musical world. The bandmasters of some notable regiments ... were trained in our own band, and there are Swanley boys in no fewer than twenty-five English, Irish, Scottish, and Welsh military bands.

The "Little Boys' Press" is justly regarded as one of the most important departments of the Home, training many of our boys in various branches of the printing trade, fitting them to take excellent positions when they leave. Every care is taken that their work and methods should be up-to-date, and from time to time new machinery is introduced to keep pace with the requirements of the printing trade. There is nothing second-rate or amateurish about the work 
done, for no fewer than forty-two of our apprentices have secured certificates at the examinations of the City and Guilds of London Institute. Boys from our printing office have held, and are still holding, responsible positions in India, Africa, Bermuda, New Zealand, and America.

As we pass from one workshop to another, see the boys in the bakery, the carpenters, the shoemakers, and tailors, we feel that we are indeed in an industrial village, for almost every necessary of life is made on the spot, and all the repairs, alterations, and renovations needed throughout the Home are done by our young carpenters, plumbers, and painters under skilled masters. Not only the clothes and boots worn by the boys, but the smart uniforms of the band are made in the tailor's shop, and the whole of the repairs for our large family neatly executed.

The most popular of the trades taught are farming and gardening. One of our boys, after holding a position at Kew, went out as botanist to a rubber expedition in Uganda. A number of our young farmers are in good situations abroad; one is managing a large estate in West Africa, and another one of 27,000 acres in the Argentine.

\section{FROM ANNUAL REPORT OF DR. BARNARDO'S HOME}

\section{Canadian Visitors' Reports concerning Boys and Girls in the Dominion.}

B. W. Called on B. and found him in the oat-field. $\mathrm{He}$ is a splendid type of vigorous manhood, and says everything is going fine with him. Is the owner of a splendid 200-acre farm. Has a good crop this year. Is married and has two fine children-a boy and a girl. Has a comfortable frame-house and good outbuildings, and everything bears an air of prosperity. Expressed himself as delighted to see a Visitor from the Home.

H. B. H. B. recently bought a 50-acre farm, and expects to move on to it shortly. He is spoken of in the neighbourhood as a very steady, industrious young fellow and a credit to the Homes. It seems hard to realise that over six years have passed since we sent $\mathrm{H}$. to his first place with his chum T. J.

C. D. is another of our old boys who is advancing to his fortunes 
in the Great West. Our latest news of C. was that he had added to his original homestead of 160 acres by the purchase of another I60 acres, and has a team of oxen with which he takes contracts for ploughing, making $\$ 3.50$ an acre. Considering that he only went West in March last, it is evident that our friend has not been letting the grass grow under his feet.

B. K. After faithfully fulfilling his apprenticeship and attaining years of discretion, B. was left to make his own arrangements for hiring, and from time to time we had good reports of him, and found that he was increasing his substance, and, better still, maintaining an excellent record. Then we learned that he had gone to the NorthWest and taken up land. The news has just now reached us that he has been paying visits to old friends, and we have gathered some tidings of our friend B.'s welfare and advancement. We hear that soon after he went to the West he took up a grant of I6o acres of land. It happened to be in a vicinity that was opened up by the building of a new railroad, and $\mathrm{B}$. was able to dispose of his homestead for $\$ 8000$. He is the owner of two teams of heavy draught-horses, and in the winter he sends these teams to the lumber woods in charge of a responsible man, and by this means they are a source of substantial revenue to him. Altogether, B. is a man of considerable substance, and that at 25 years of age, and as the result entirely of hard work and steady perseverance.

$\mathrm{H}$. M. is a young man of whom we can say nothing but what is good. He has a record of twelve years in Canada of good work and steady progress. In his last letter he says: "I am getting along fine, enjoy good health, and have a bank account of $\$ 600$ saved up. At present I am working for Mr. B., and get $\$ 185$ a year."

P. T. We learn that our friend and silver-medallist P. T. is organist at the Sabbath School, and other circumstances are mentioned of him that show that he is one that merited a high place on our roll of honour. P. has been nine years in the same locality, and we think that we may say that he has found favour in the eyes of all with whom he has had to do. 


\section{APPENDIX B}

\section{EXTRACT FROM ANNUAL REPORT OF INDUSTRIAL SCHOOL, NO. 2}

In my Annual Report to the Home Office of boys discharged during 1907 , 1908, and 1909, there are 55 boys employed as follows :-

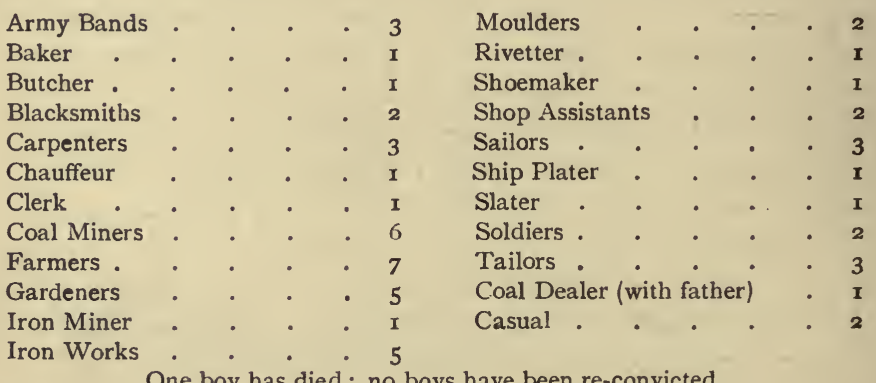

One boy has died; no boys have been re-convicted. 


\section{APPENDIX C}

\section{ASSOCIATION FOR BEFRIENDING BOYS}

\section{Rules for the Hon. District Secretaries}

(I) The Hon. District Secretaries are appointed by the Executive Committee.

(2) Visitors are appointed in each district by the Hon. District Secretary of that district.

(3) A district book is supplied by the Central Office to each Hon. District Secretary, containing the names of all the boys placed out in his or her district, and this book must be kept up to date with the history in detail of each boy as laid down in the particulars required on the Blue Report Form. The Executive Committee reserves the right of asking to see this book at any time.

(4) The Hon. District Secretaries should see that suitable visitors are found to befriend all boys put under their care, and should obtain regular reports from the visitors on each boy assigned to them.

(5) When a new boy is placed out in any district, information is sent by the Central Office on a White Form or History Sheet to the Hon. District Secretary, so that his name may be entered in the Report Book, and that he may be assigned to the care of a visitor.

(6) Blue Report Forms are supplied to each Hon. District Secretary on application to the Central Office. These should be sent out twice a year to each visitor for the purpose of securing a full report on each boy every six months.

(7) The Hon. District Secretary, after the receipt of the Blue Report forms from each visitor, should enter the information therein contained in his or her District Book, and having done so should forward the forms to the Central Office, so that they may be attached to the case-papers to which they refer. The Hon. District Secretary must arrange with the visitors as to sending in their reports on 
the Blue Report Forms, so that he or she may be able to forward them to the Central Office by April I 5 and October I 5 in each year at the latest.

(8) The Blue Report Forms must contain the complete history of each boy for the previous six months, and be duly signed and countersigned by the visitor and the Hon. District Secretary and carefully dated.

(9) If a visitor fails to trace a boy, information must be given at once to the Hon. District Secretary, and the latter must without delay pass it on to the Central Office.

(Io) Should a visitor need advice on any boy, he or she should apply to the Hon. District Secretary, who, if necessary, will refer to the Central Office, so that the case may be brought before the Executive Committee at its next monthly meeting.

(I I) Letters and reports about boys, whether sent by the Hon. District Secretary to the Central Office or by a visitor to the Hon. District Secretary, should relate to one boy only, so that the information may be attached as it stands to the case-paper of the boy to which it refers.

(I2) Visitors are directly responsible for their work to the Hon. District Secretary, and the latter is directly responsible to the Central Office.

(13) When a boy moves from one district to another, his new address must at once be forwarded to the Central Office. It will then be notified to the District Secretary of the district into which he has moved. If in any case the visitor who has hitherto looked after the boy desires to continue to do so, his or her half-yearly report on that boy must be forwarded to the District Secretary of the district into which he has moved.

Printed by Ballantyne, Hanson \& Co.

Edinburgh \& London 


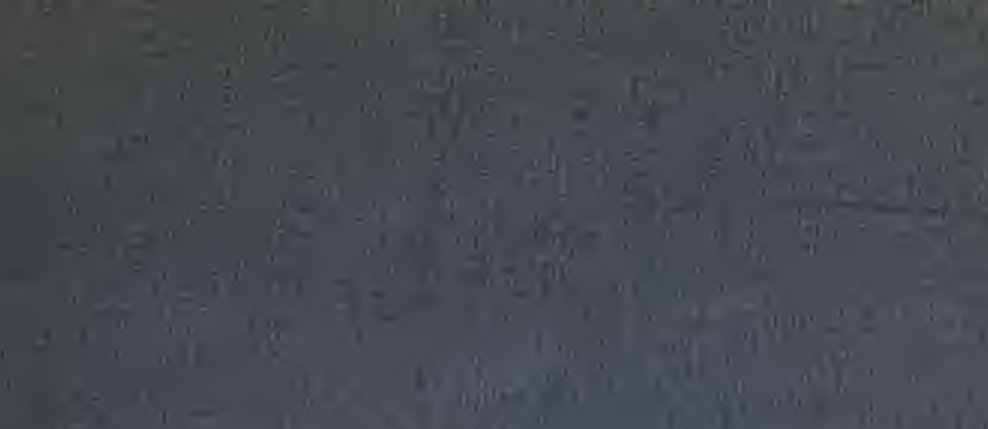

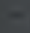

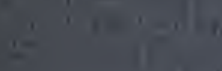
(1)

\section{(i) को}

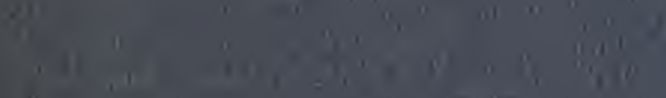

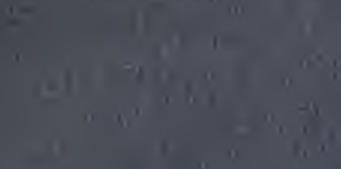

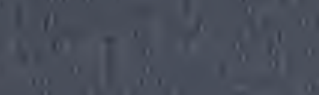

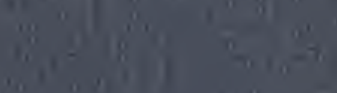




\section{BIRMINGHAM STUDIES IN SOCIAL ECONOMICS.}

Edited by W. J. Ashley.

ENVIRONMENT AND ETnIN TUDY

THIS BOOK IS DUE ON THE LAST DATE RIAL

By AN INITIAL FINE OF 25 CENTS

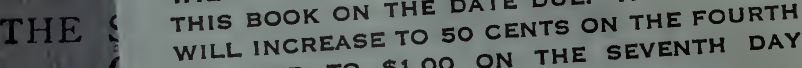
DAY AND
OVERDUE.

\section{THE \\ S \\ By $\mathrm{N}$ \\ ment}

AN IN

$$
\text { H. }
$$

By W

Part

Part I

THE AI

A Stur Ameri

BRITISH

A Serik

$\mathrm{By} \mathrm{Va}$

5s. $6 d$.

BRITISH

ME

A Serie

Edited

MILL'S $\mathbf{P}$

NEW E

Crown 8 STAMPED BELOW AN INITIAL FE FOR FAILURE TO RETURN WILL BOOK ON THE DATE DUE. THE PENALTY

8vo,

H A SURAIN. et. ARY MAY 81946 ettleDEC 23 ISA

NOV 231937

NOV 19939

JUN 51942

ettle-

MIC

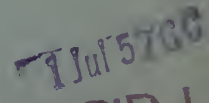

REC'D LD

JUL 1 195

APR 2 1841M 12 Mar'63CB

and

net.

ts.

vo,

OCT $27: 549$

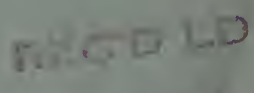

FEB 261963 M- 
Syrocuse, N.Y.

Stockton, Calif. 
